\title{
The health and development of children born after preimplantation genetic diagnosis
}

Citation for published version (APA):

Heijligers, M. (2021). The health and development of children born after preimplantation genetic diagnosis. [Doctoral Thesis, Maastricht University]. Maastricht University. https://doi.org/10.26481/dis.20210421mh

Document status and date:

Published: 01/01/2021

DOI:

10.26481/dis.20210421mh

Document Version:

Publisher's PDF, also known as Version of record

\section{Please check the document version of this publication:}

- A submitted manuscript is the version of the article upon submission and before peer-review. There can be important differences between the submitted version and the official published version of record. People interested in the research are advised to contact the author for the final version of the publication, or visit the DOI to the publisher's website.

- The final author version and the galley proof are versions of the publication after peer review.

- The final published version features the final layout of the paper including the volume, issue and page numbers.

Link to publication

\footnotetext{
General rights rights.

- You may freely distribute the URL identifying the publication in the public portal. please follow below link for the End User Agreement:

www.umlib.nl/taverne-license

Take down policy

If you believe that this document breaches copyright please contact us at:

repository@maastrichtuniversity.nl

providing details and we will investigate your claim.
}

Copyright and moral rights for the publications made accessible in the public portal are retained by the authors and/or other copyright owners and it is a condition of accessing publications that users recognise and abide by the legal requirements associated with these

- Users may download and print one copy of any publication from the public portal for the purpose of private study or research.

- You may not further distribute the material or use it for any profit-making activity or commercial gain

If the publication is distributed under the terms of Article $25 \mathrm{fa}$ of the Dutch Copyright Act, indicated by the "Taverne" license above, 


\section{The health and development of children born after preimplantation genetic diagnosis}

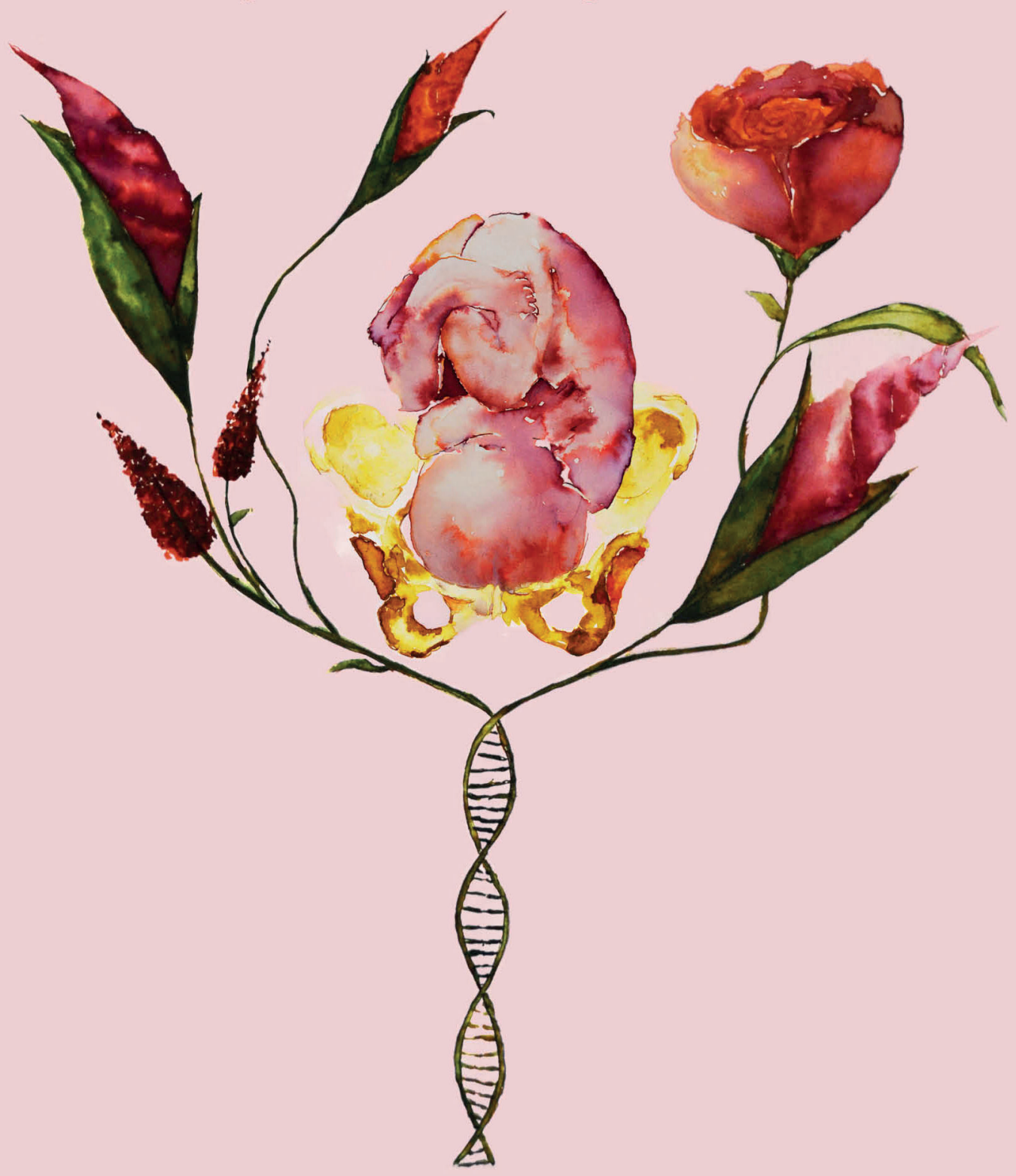


The health and development of children born after preimplantation genetic diagnosis 
The research presented in this thesis was conducted within GROW School for Oncology and Developmental Biology, at the Department of Clinical Genetics of the Maastricht University Medical Center (MUMC+).

The studies described in this thesis were funded by The Netherlands Organization for Health Research and Development (ZonMw, grant number: 70-71300-98-106 and 7073000-98-210) and Academisch Alliantie Fonds MUMC+

\section{oga zonMw (4) Maastricht UMC+}

The health and development of children born after preimplantation genetic diagnosis

\section{PROEFSCHRIFT}

ter verkrijging van de graad van doctor aan de Universiteit Maastricht, op gezag van de Rector Magnificus, Prof. Dr. Rianne M. Letschert, volgens het besluit van het College van Decanen,

in het openbaar te verdedigen

op woensdag 21 april 2021 om 10.00 uur

door

Malou Heijligers

Copyright (C) Malou Heijligers 2021

All rights reserved. No part of this publication may be reproduced, stored in a database or retrieval system, or transmitted in any for or by any means without prior written permission of the author, or when appropriate, the publisher of the papers.

Cover design: Julia Heijligers | juliaheijligers.com

Layout: Tiny Wouters

Printing: Idesign | idesign-velden.n|

ISBN: 978-90-9034425-6 
Promotor:

Prof. dr. C.E.M. de Die-Smulders

\section{Co-promotores:}
Dr. Y.H.J.M. Arens
Dr. A.P.A. van Montfoort

\section{Beoordelingscommissie:}

Em. prof. dr. C.T.R.M. Stumpel (voorzitter)

Dr. E.K. Bijlsma (Leids Universitair Medisch Centrum)

Prof. dr. K. Devriendt (Universitair Ziekenhuis Leuven)

Dr. J.E. den Hartog

Prof. dr. M.E.A. Spaanderman

\section{Contents}

Chapter 1

General introduction

Chapter 2 Obstetric risks associated with preimplantation genetic testing for monogenic disorders and structural chromosoma rearrangements (PGT-M/SR) compared to regular IVF/ICSI submitted

Chapter 3 Perinatal follow-up of children born after preimplantation genetic diagnosis in the Netherlands between 1995 and 2014 J Assist Reprod Genet. 2018;35(11):1995-2002

Chapter $4 \quad$ Growth, health and motor development of 5-year-old children born after preimplantation genetic diagnosis Fertil Steril. 2019;111(6):1151-1158

Chapter 5 The cognitive and socio-emotional development of 5-year-old children born after PGD

Hum Reprod. 2018:33(11):2150-2157

Chapter 6 General discussion

Summary

Samenvatting

Valorization

Dankwoord

Curriculum vitae 


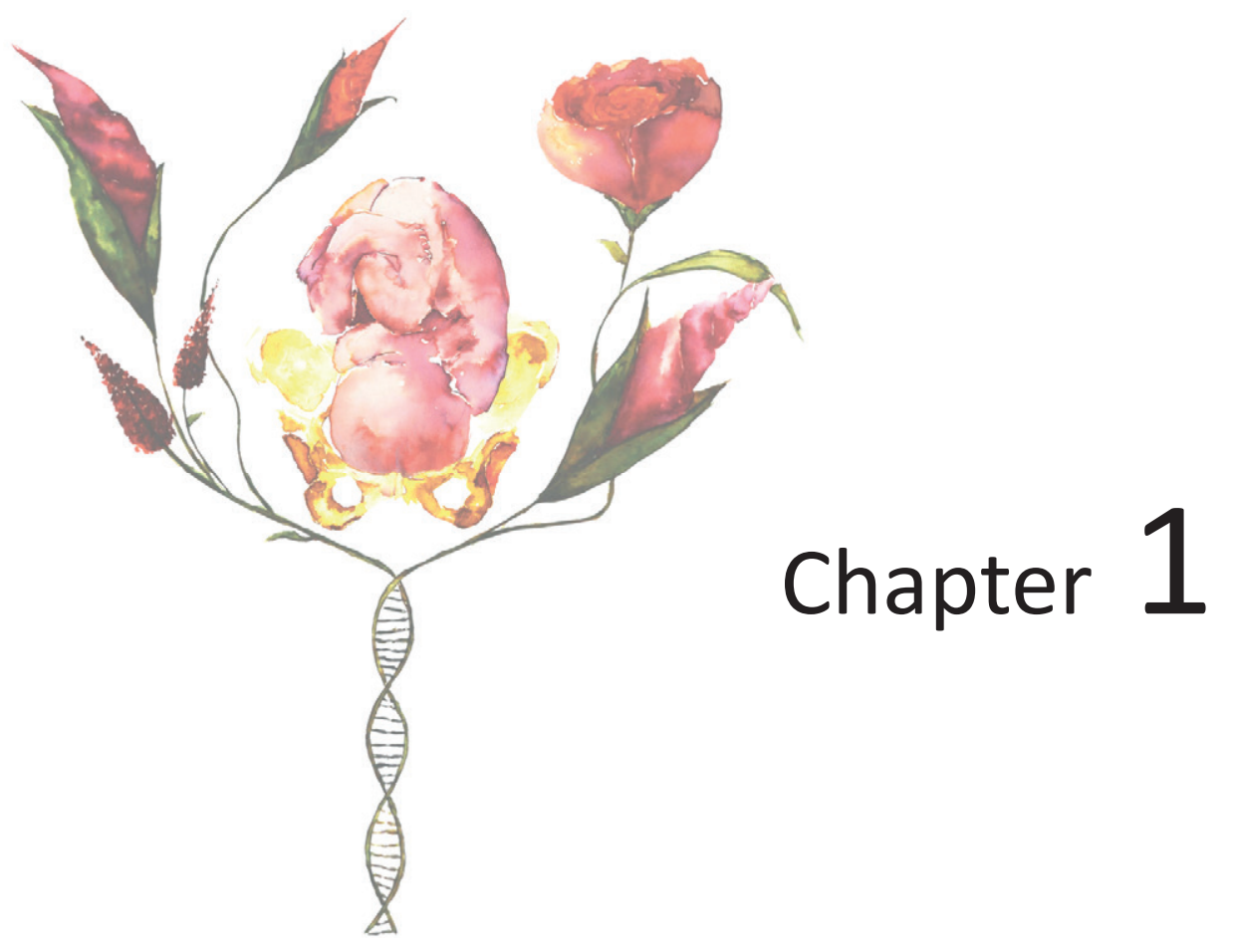

General introduction 


\section{General introduction}

Preimplantation genetic diagnosis (PGD), also known as preimplantation genetic testing (PGT), is offered to couples with a high risk of having a child with a severe genetic disorder or with an increased risk of miscarriages due to a structural chromosomal rearrangement. The use of PGD provides couples the opportunity to know the genetic status before the embryo is implanted in the uterus and thus to select embryos without the genetic disorder running in their family or with the familial unbalanced karyotype. Therewith PGD is a fair reproductive option for couples at risk in addition to the spectrum of already existing reproductive choices such as prenatal testing, gamete donation, acceptance of the risk or refraining from having children. Contrary to prenatal testing, PGD makes it possible to avoid the selective abortion of fetuses affected with a hereditary disorder. ${ }^{1}$

PGD is considered to be a complex medical intervention associated with human reproduction. It is therefore a delicate topic for both medical experts and society. This thesis is about the safety of PGD.

\section{PGD in the Netherlands}

PGD was introduced in the Netherlands in 1995 and the requests for PGD are increasing since, starting from less than 50 referrals in the first years to more than 500 referrals per year at the moment. ${ }^{2}$ The Maastricht University Medical Center+ (MUMC+) is the only center licensed to offer PGD services. Since 2008, patients can also get general information about PGD and undergo the IVF/ICSI procedure in the University Medical Center Utrecht, University Medical Center Groningen or the Amsterdam University Medical Center. Together the MUMC+ and the three so-called transport centers have united to form PGD the Netherlands. The PGD the Netherlands' activities are coordinated by the PGD Medical Coordinator who is allocated at the MUMC+. The PGD Medical Coordinator is supported by MUMC+'s multidisciplinary PGD working group consisting of clinical geneticists, laboratory geneticists, gynecologists, embryologists, ethicists and laboratory technicians. If necessary, several medical specialists or professionals, for instance psychologists, oncologists or neurologists, can be consulted. Each of the transport centers has a comparable multidisciplinary PGD team, but the MUMC+'s PGD working group is responsible for the proper implementation of the agreed policies. 
In 2009 the Ministry of Public Health, Welfare and Sport decided that all new indications for PGD should be evaluated by an independent so-called PGD National Indications Committee. This decision followed a nationwide discussion about offering PGD for late-onset disorders with incomplete penetrance, such as hereditary breast and ovarian cancer, and the accompanying questions about the moral acceptability of certain indications for PGD. ${ }^{3}$ The PGD National Indications Committee consists of delegates from the national association of clinical geneticist and the national association of gynecologists, ethicists and a representative of the patient organizations. This committee evaluates whether a new indication for PGD meets legal and ethical standards, as formulated in the "Embryowet" and in the PGD guidelines as published in the Staatscourant. ${ }^{4}$

The increasing number of referrals for PGD might be due to the improved technical possibilities to diagnose genetic disorders and to the growing knowledge of health care providers and the public about genetics in general and also about PGD. ${ }^{5,6}$ Such growing knowledge also increases the involvement of Dutch citizens, as well as the government, in discussions about the introduction of new medical techniques and treatments like PGD. While there is a broad political and societal support for PGD, the use of such a new and innovative technique also raises questions with regard to the safety of PGD. Safety questions include concerns regarding the safety of the treatment itself for the women undergoing PGD, as well as concerns about the impact of the treatment on the health and wellbeing of the children born after PGD. Also, the quality of life of (healthy) children born after PGD growing up in families with serious genetic disorders that may affect parental competence (such as Huntington's disease) can be a concern. ${ }^{7}$ Several ethical and societal questions are related to safety, such as the moral acceptability of certain indications for PGD, i.e. less penetrant mutations and highly variable disorders.

\section{The PGD procedure}

The combination of techniques used for PGD contributes to the complexity of the treatment, starting with in-vitro fertilization (IVF) treatment, which is necessary to obtain preimplantation embryos, followed by a biopsy, which is necessary for the genetic analysis.
For PGD, oocytes, retrieved from the ovary after ovarian hyperstimulation, are fertilized either by conventional IVF or intracytoplasmic sperm injection (ICSI). Traditionally, on day three after fertilization one blastomere (or incidentally two) is biopsied from the cleavage stage embryo by creating a hole in the zona pellucida using a laser. The biopsied blastomere is tested for the familial genetic disorder. ${ }^{8-10}$ Recently, a new biopsy method was introduced, called trophectoderm biopsy (TE biopsy). TE biopsy is done at day five or six after fertilization, when the embryo has developed into a blastocyst. It provides the opportunity to collect 5 to 10 cells per embryo. ${ }^{11}$

The successful application of polymerase chain reaction (PCR) for the Y-chromosome on blastomeres, performed for the selection of X-linked disorders, preluded the first steps into the PGD era. ${ }^{12}$ The use of this technique enabled the selection of female embryos which were not at increased risk of developing the genetic disease. FISH, and later array-CGH, was used for the evaluation of chromosomal imbalances. ${ }^{8}$ The application of PCR techniques on single cells eventually made it possible to select for monogenic and mitochondrial disorders. ${ }^{9,13}$ PCR based PGD analyses consists of either direct mutation analyses in combination with at least one microsatellite marker flanking the gene or indirect analyses with multiple microsatellite markers. ${ }^{10,14,15}$ Mutation detection is performed using fragment length (insertions/deletions) or the double allele amplification refractory mutation systems (D-ARMS) technique (single base pair changes). Mitochondrial DNA mutations require a semi-quantitative test. ${ }^{9,10,14,15}$ Nowadays, Next Generation Sequencing (NGS) is used preferentially for the detection of chromosomal abnormalities as well as for the analysis of monogenic disorders. The upcoming NGS based SNP-haplotyping will probably be feasible for all indications in one test, i.e. the OnePGT test, thereby enabling PGD for combined monogenic and chromosomal anomalies. Aneuploidy screening is currently not performed in the Dutch PGD clinics. ${ }^{14}$

At the time of the genetic analysis, the development of the embryos is closely monitored in the IVF lab. In case of biopsy on day three, preferably one embryo, without the target condition in the biopsied cell(s), is transferred in utero on day three or four after the oocyte retrieval. ${ }^{8-10}$ In case of TE biopsy, the timing of the biopsy makes cryopreservation of the embryos necessary as modern diagnostic procedures cannot be performed and completed in two days. Thawing of the embryo and transfer 
to the uterus usually takes place several weeks after the IVF procedure, resulting in enough time for the complex genetic analysis. ${ }^{11}$ In the Netherlands, by law, the transfer of two embryos is only allowed in the third treatment cycle or if the woman is 38 years or older.

If the transfer after either blastomere biopsy or TE biopsy results in a viable pregnancy the couple is offered invasive prenatal testing in order to verify the PGD analysis. Additionally, all couples are offered an ultrasound anomaly scan at 18-20 weeks of gestational age as part of regular prenatal care. ${ }^{8,9}$

\section{PGD indications and alternative reproductive options}

PGD was initially offered to couples with a high risk of having a child with either a severe, early onset or lethal, monogenic, mitochondrial or chromosomal disorder or with a high risk of miscarriages due to a structural chromosomal abnormality. Nowadays, PGD is also approved for late-onset disorders, or disorders with incomplete penetrance. The most common indications for PGD are chromosomal aberrations and autosomal dominant disorders, in particular Huntington's disease and hereditary breast and ovarian cancer (HBOC). ${ }^{2}$

A common alternative for PGD is to pursue a natural conception and choose for invasive (chorionic villus sampling or amniotic fluid sampling) or non-invasive prenatal testing (NIPT). ${ }^{16}$ When the fetus is affected, the couple can decide to terminate the pregnancy. NIPT for gender determination (performed in case of a familial X-linked disorder), aneuploidy detection and for detection of large chromosomal rearrangements is available. NIPT is a safe method and can now be offered from a pregnancy duration of 11 weeks gestational age. Current NIPT diagnosis has to be confirmed by invasive prenatal testing as the positive predictive value is not $100 \%$. In the nearby future, couples will probably get the opportunity to opt for non-invasive prenatal diagnosis (NIPD) for monogenic disorders. ${ }^{17}$ It is still an open question if and when NIPT/NIPD can be applied reliably very early in pregnancy. Other options for couples with a high risk of transmitting a genetic disease to their offspring are to pursue a natural conception without any genetic testing, to use donor semen or donor oocytes or to apply for adoption. Some couples eventually end up without fulfilling their desire to have children.
Couples' motives and reasons regarding their choice for PGD are mostly based on personal experience and reproductive history. ${ }^{1}$ Our research group found that couples who experienced one or more pregnancy terminations, or couples with a history of subfertility, more often choose for PGD. Whereas couples who have an affected living child at home often consider PGD, but eventually refrain from the actual use of PGD. ${ }^{1}$ Furthermore, general aspects of the PGD procedure, like the avoidance of pregnancy termination, the burden of the IVF treatment and the relatively low pregnancy rate when compared to natural conception, are taken into account by the couples. ${ }^{16}$

Studies on the reproductive decision-making process in couples with a high risk on offspring with $\mathrm{HBOC}$ report on additional disease specific arguments for and against PGD. An important issue for women with a high risk on $\mathrm{HBOC}$ is the safety of the IVF procedure for themselves (especially the hormonal stimulation) and the time to pregnancy, since the time to pregnancy affects the timing of prophylactic surgery. ${ }^{3} \mathrm{~A}$ history of cancer and the perceived seriousness of the disorder also influences the consideration to use PGD for HBOC. ${ }^{5}$

Based on the diversity of the arguments for and against PGD the need for a decision support tool for couples with hereditary cancer was evaluated. Couples with hereditary cancer, as well as their health care providers, considered that such a tool would be valuable during their decision-making process. ${ }^{18}$

\section{The safety of PGD}

The whole PGD procedure, starting from the first visit to the clinic until the birth of a child, can take months to even years. Couples may experience this period as very stressful and intensive. ${ }^{19}$ Part of the couples have a complex reproductive history with infertility, multiple miscarriages and/or pregnancy terminations, have an affected child at home or are affected with or in the prodromic phase of a genetic disorder themselves. ${ }^{1}$ Considering all the above mentioned factors, one can imagine the fragility of a PGD pregnancy.

The chance of being pregnant after a first PGD treatment is about 20\%, whereas $90 \%$ of the couples in the general population conceive naturally within a year. ${ }^{20,21}$ As a rule, couples with a Dutch health care insurance will get a restitution for three PGD cycles 
per child. Thus, their overall chance on a liveborn child is probably lower than for couples who try to conceive naturally.

Information about the expected pregnancy course is of great importance for both health care providers as well as for couples opting for PGD. Studies on obstetric and perinatal outcome of pregnancies following PGD treatment are, however, scarce. In (Dutch) practice, most women who are pregnant after PGD undergo regular pregnancy check-ups at a midwife clinic. It may be debated if these currently provided regular check-ups are enough when PGD might increase the risk on adverse obstetric outcome. In addition, some of the women undergoing PGD also have an increased risk for obstetric complications due to the present genetic disorder, e.g. women suffering from a neuromuscular disorder like myotonic dystrophy. ${ }^{22}$

Not only evaluation of obstetric risks, but also evaluation of the pregnancy course is important. The European Society of Human Reproduction and Embryology (ESHRE) repeatedly reports on the cumulative PGD results of all the affiliated PGD centers. In 2017 they reported a miscarriage in $12 \%$ of the pregnancies with a fetal heartbeat, which is similar to the miscarriage rate reported in another study. ${ }^{20,23}$ Fetal loss in the second and third trimester, more specifically the risk of stillbirths, is another point of concern. Especially since one study, which was performed in Belgium, raised concerns about a possible increased risk of stillbirths in pregnancies following either PGD or preimplantation genetic screening (PGS). ${ }^{24}$ Up until now, other studies could neither validate or refute these concerns due to small study samples. ${ }^{23}$

Overall, knowledge about the obstetric and perinatal risks in pregnancies following PGD will contribute to provision of more reliable information to individual couples and the formation of guidelines or screening advises for healthcare providers who support women who are pregnant after PGD.

The idea of conceiving in vitro without having any consequence is hard to believe for many people. This concern is in line with the Developmental Origin of Health and Disease (DOHaD) hypothesis discussing the link between early embryonic development and health later in life. ${ }^{25}$ This hypothesis states that the risk for the development of diseases later in life finds its origin during early development and can be negatively influenced by environmental stressors. ${ }^{25}$ This is especially relevant for pregnancies after assisted reproductive technology (ART), given the fact that the ART procedure interferes in the period of this early development. The need for a biopsy in PGD on top of the IVF procedure can even be an extra stressor for the development of the embryo. An exhausting evaluation of the safety of such a biopsy, and thus the PGD procedure, is still lacking. ${ }^{26}$ Therefore there is an urge for careful evaluation of the health of children born after PGD. One of the main outcome measures evaluated in newborns born after PGD is the incidence of congenital malformations. ${ }^{23,24,27-30}$ Secondly, the growth of the fetus can be influenced by the artificial environment the zygote and embryo are exposed to during an IVF/PGD treatment. ${ }^{25}$

Studies on the postnatal growth of children born after IVF report that these children have lower mean birth weight than naturally conceived children and that they show rapid catch-up growth in their early years of life which can probably lead to an increased risk of cardiovascular disease later in life. ${ }^{31,32} \mathrm{~A}$ study in a Belgian cohort of 2-year-old children born after PGD reports similar growth when compared to children born after IVF/ICSI. ${ }^{33}$ Further evaluation of the growth of (older) children born after PGD, as well as of their general health, including acute and chronic illnesses, medication use and use of health care, is needed.

Health has not only a physical aspect, but is defined by the World Health Organization as 'a state of complete physical, mental and social well-being and not merely the absence of disease or infirmity'. ${ }^{34}$ Both mental and social well-being can be influenced by the physical health of a person, but also by the person's environment. Growing up in a family with a family member (parent or sibling) with a severe illness, which is common for children born after PGD, can influence a child's well-being. ${ }^{35}$ Children with either physical, mental or social problems might also experience an adverse development on several domains. Evaluation of, for instance, the socio-emotional and cognitive development of the children can clarify a possible need for extra support.

Overall, the health of both newborns and older children born after PGD need to be thoroughly examined in order to offer couples and health care providers a complete overview of the possible risks of PGD. 


\section{Aims of this thesis}

The general aim of this thesis is to evaluate the safety of PGD. The specific research questions are:

\section{- Does PGD increase the risk on adverse obstetric outcome?}

In chapter 2 all PGD pregnancies from the start of PGD in the Netherlands until 2014 are evaluated. The results are compared to results from IVF pregnancies and population data.

Do children born after PGD have a higher risk for congenital malformations or adverse perinatal outcomes?

The perinatal results of all children born after PGD between 1995 and 2014 are reported in chapter 3. This chapter focuses on the congenital malformation rate, misdiagnosis rate, birth parameters and perinatal mortality and morbidity.

\section{- Does PGD influence the growth, health and development of the offspring?}

This topic is addressed in two separate studies. Chapter 4 reports on a study on the growth and health of 5-year-old children born after PGD compared to children born after IVF/ICSI and naturally conceived children from families with a genetic disorder. Chapter 5 reports on the cognitive and socio-emotional development in children born after PGD and their controls.

Finally, chapter 6 , is a general discussion including all study results and possible impact for reproductive practice.

\section{References}

1. van Rij MC, Gielen M, Lulofs R, et al. Profiles and motives for PGD: a prospective cohort study of couples referred for PGD in the Netherlands. Hum Reprod. 2011;26(7):1826-1835.

Annual report PGD Netherlands, 2018. Avaliable at https://www.pgdnederland.nl/jaarverslagen.

3. Derks-Smeets IA, Gietel-Habets JJ, Tibben A, et al. Decision-making on preimplantation genetic diagnosis and prenatal diagnosis: a challenge for couples with hereditary breast and ovarian cancer. Hum Reprod. 2014;29(5):1103-1112.

4. Bussemaker M. Regeling preimplantatie genetische diagnostiek van de staatssecretaris van Volksgezondheid, Welzijn en Sport (Regulations of the State Secretary of Public Health, Welfare and sport on the rules concerning PGD). Staatscourant Koninkrijk der Nederlanden 2009; 42(42):1-12.

5. Gietel-Habets JJ, de Die-Smulders CE, Derks-Smeets IA, et al. Awareness and attitude regardin reproductive options of persons carrying a BRCA mutation and their partners. Hum Reprod. 2017;32(3):588-597.

6. Gietel-Habets JJG, de Die-Smulders CEM, Tjan-Heijnen VCG, et al. Professionals' knowledge, attitude and referral behaviour of preimplantation genetic diagnosis for hereditary breast and ovarian cancer. Reprod Biomed Online. 2018;36(2):137-144.

7. Dondorp W, de Wert G. Refining the ethics of preimplantation genetic diagnosis: A plea for contextualized proportionality. Bioethics. 2019;33(2):294-301.

8. Harton GL, Harper JC, Coonen E, et al. ESHRE PGD consortium best practice guidelines for fluorescence in situ hybridization-based PGD. Hum Reprod. 2011;26(1):25-32.

9. Harton GL, De Rycke M, Fiorentino $F$, et al. ESHRE PGD consortium best practice guidelines for amplification-based PGD. Hum Reprod. 2011;26(1):33-40.

10. Sermon $K$, Van Steirteghem A Liebaers I. Preimplantation genetic diagnosis, Lancet. 2004;363(9421):1633-1641.

11. Martín J, Cervero A, Mir P, Martinez-Conejero JA, Pellicer A, Simón C. The impact of next-generation sequencing technology on preimplantation genetic diagnosis and screening [published correction appears in Fertil Steril 2013 Mar:99(6):1798. Conejero Martinez, Jose Antonio [corrected to Martinez-Conejero, Jose Antonio]]. Fertil Steril. 2013;99(4):1054-61.e3.

12. Handyside $\mathrm{AH}$, Kontogianni $\mathrm{EH}$, Hardy $\mathrm{K}$, Winston RM. Pregnancies from biopsied human preimplantation embryos sexed by Y-specific DNA amplification. Nature 1990:344(6268):768-770.

Dreesen It, Destouni A, Kourlaba $G$, et al. Evaluation of PCR-based preimplantation genetic diagnosis applied to mono ic diseases: a collaborative ESHRE PGD consortium study. Eur I Hum Genet. 2014;22(8):1012-1018.

14. Renwick PJ, Trussler J, Ostad-Saffari E, et al. Proof of principle and first cases using preimplantation Rentic haplotyping--a paradigm shift for embryo diagnosis. Reprod Biomed Online. 2006;13(1):110-

15. Dimitriadou $E$, Melotte $C$, Debrock $S$, et al. Principles guiding embryo selection following genomewide haplotyping of preimplantation embryos. Hum Reprod. 2017;32(3):687-697.

16. Pergament $E$, Pergament $D$. Reproductive decisions after fetal genetic counselling. Best Pract Res Clin Obstet Gynaecol. 2012;26(5):517-529.

17. Lench $\mathrm{N}$, Barrett $\mathrm{A}$, Fielding $\mathrm{S}$, et al. The clinical implementation of non-invasive prenatal diagnosis for single-gene disorders: challenges and progress made. Prenat Diagn. 2013;33(6):555-562.

18. Reumkens K, van Oudheusden AJG, Gietel-Habets JJG, Tummers MHE, de Die-Smulders CEM, van Osch LADM. Reproductive Decision Support: Preferences and Needs of Couples at Risk for Hereditary Cancer and Clinical Geneticists. I Genet Couns. 2018;27(4):920-926.

19. Gietel-Habets JJG, de Die-Smulders CEM, Derks-Smeets IAP, et al. Support needs of couples with hereditary breast and ovarian cancer during reproductive decision making. Psychooncology. 2018;27(7):1795-1801.

20. De Rycke M, Goossens V, Kokkali G, Meijer-Hoogeveen M, Coonen E, Moutou C. ESHRE PGD Consortium data collection XIV-XV: cycles from January 2011 to December 2012 with pregnancy follow-up to October 2013. Hum Reprod. 2017;32(10):1974-1994. 
21. van Eekelen R, Scholten I, Tjon-Kon-Fat RI, et al. Natural conception: repeated predictions over time. Hum Reprod. 2017;32(2):346-353.

22. Awater C, Zerres K, Rudnik-Schöneborn S. Pregnancy course and outcome in women with hereditary neuromuscular disorders: comparison of obstetric risks in 178 patients. Eur J Obstet Gynecol Reprod Biol. 2012;162(2):153-159.

23. Hasson J, Limoni D, Malcov M, et al. Obstetric and neonatal outcomes of pregnancies conceived after preimplantation genetic diagnosis: cohort study and meta-analysis. Reprod Biomed Online. 2017;35(2):208-218.

24. Liebaers I, Desmyttere S, Verpoest W, et al. Report on a consecutive series of 581 children born after blastomere biopsy for preimplantation genetic diagnosis. Hum Reprod. 2010;25(1):275-282.

25. Feuer S, Rinaudo P. Preimplantation stress and development. Birth Defects Res C Embryo Today. 2012;96(4):299-314.

26. Zacchini F, Arena R, Abramik A, Ptak GE. Embryo biopsy and development: the known and the unknown. Reproduction. 2017:154(5):R143-R148.

27. Bay B, Ingerslev HJ, Lemmen JG, Degn B, Rasmussen IA, Kesmodel US. Preimplantation genetic diagnosis: a national multicenter obstetric and neonatal follow-up study. Fertil Steril. 2016;106(6):1363-1369.e1.

28. Banerjee I, Shevlin M, Taranissi M, et al. Health of children conceived after preimplantation genetic diagnosis: a preliminary outcome study. Reprod Biomed Online. 2008;16(3):376-381.

29. Desmyttere S, De Rycke M, Staessen C, et al. Neonatal follow-up of 995 consecutively born children after embryo biopsy for PGD. Hum Reprod. 2012;27(1):288-293.

30. Eldar-Geva T, Srebnik N, Altarescu G, et al. Neonatal outcome after preimplantation genetic diagnosis. Fertil Steril. 2014;102(4):1016-1021.

31. Bay B, Mortensen $E$, Kesmodel US. Assisted reproduction and child neurodevelopmental outcomes: a systematic review. Fertil Steril. 2013;100(3):844-853.

32. Ceelen $M$, va Weissenbru $M M$, Prein $J$ et al. Grow th during infancy and early childhood in relation to blod pressure and body

33. Desmyttere S, Bonduelle M, Nekkebroeck J, Roelants M, Liebaers I, De Schepper J. Growth and health outcome of 102 2-year-old children conceived after preimplantation genetic diagnosis or screening. 2009;85(12):755-759.

WHO definition of 'health'. Stud Hastings Cent. 1973;1(3):77-88.

Romer G, Barkmann C, Schulte-Markwort M, Thomalla G, Riedesser P. Children of Somatically III Parents: A Methodological Review. Clinical Child Psychology and Psychiatry 2002;7(1):17-38.

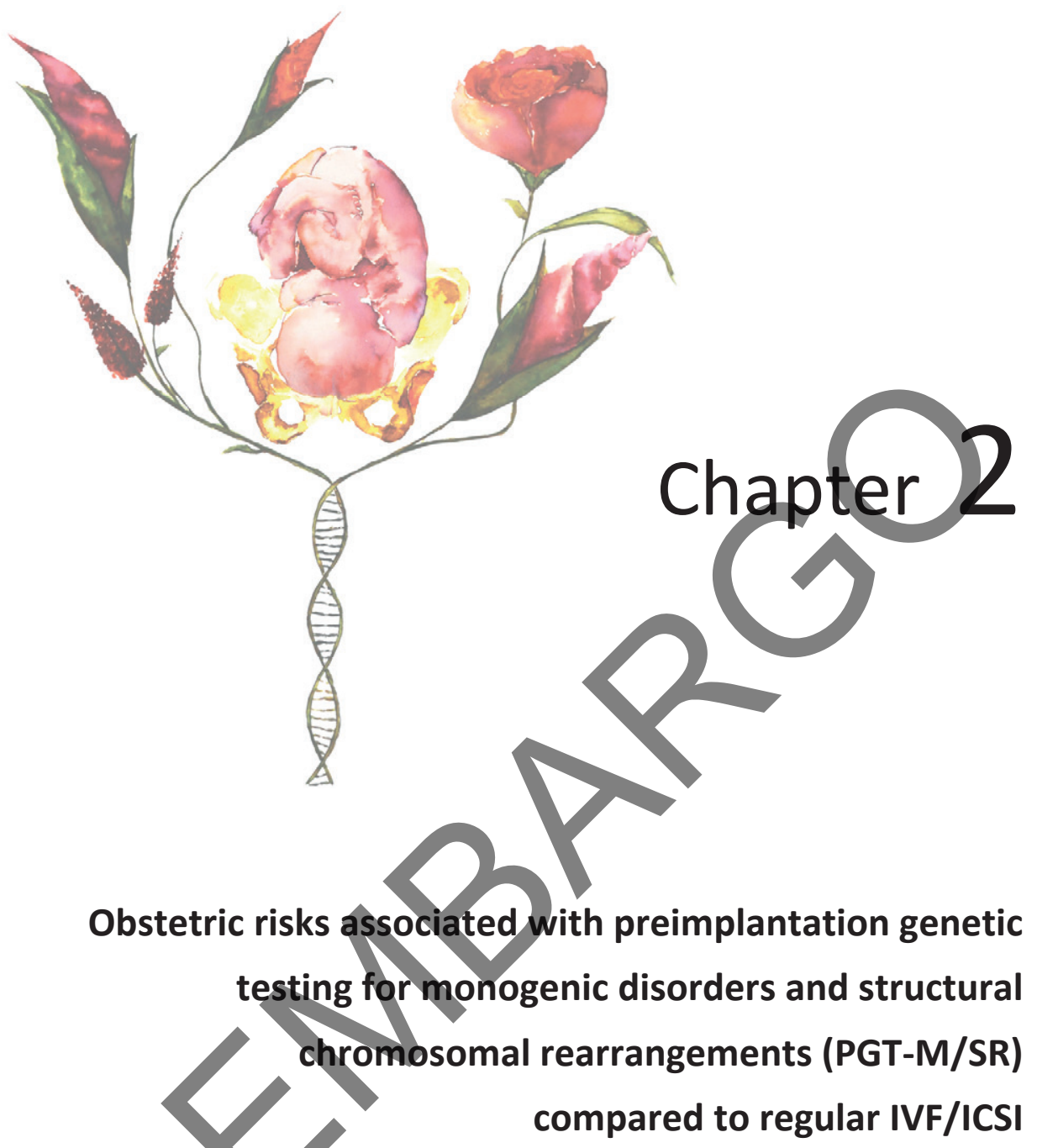

M. Heijligers, Y.H.J.M. Arens, R.J.T. van Golde, M.A.H.B.M. van der Hoeven, J.C.M. Dumoulin, I. Homminga, T.C. van Tilborg, C.E.M. de Die-Smulders, A.P.A. van Montfoort 


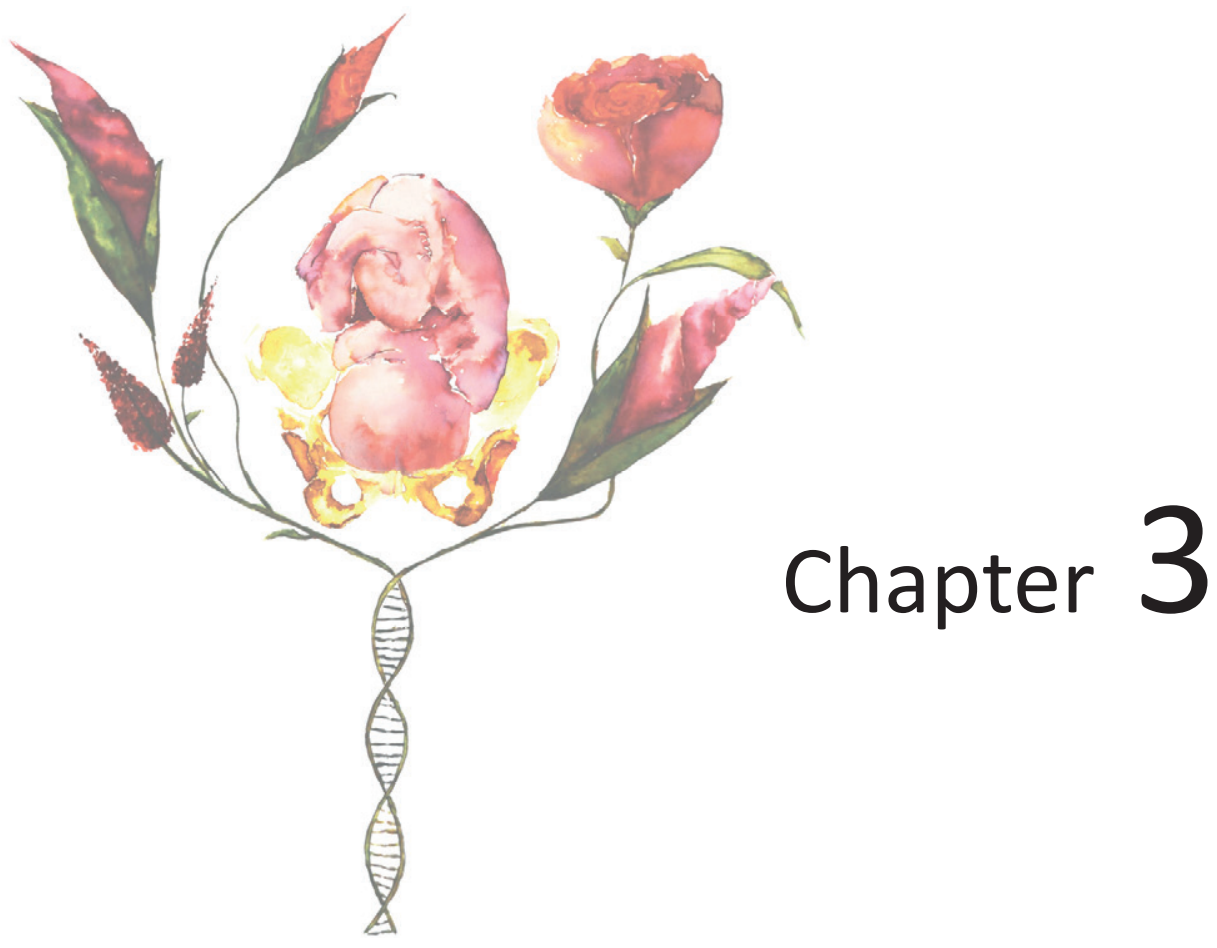

Perinatal follow-up of children born after preimplantation genetic diagnosis in

the Netherlands between 1995 and 2014

M. Heijligers, A.P.A. van Montfoort, M. Meijer-Hoogeveen, F.K. Broekmans, K. Bouman, I. Homminga, J. Dreesen, A. Paulussen, J. Engelen, E. Coonen, V. van der Schoot, M. van Deursen-Luijten, N. Muntjewerff, A. Peeters, R. van Golde M.A.H.B.M. van der Hoeven, Y. Arens, C.E.M. de Die-Smulders J Assist Reprod Genet. 2018;35(11):1995-2002 


\section{Abstract}

\section{Purpose}

We aim to evaluate the safety of PGD. We focus on the congenital malformation rate and additionally report on adverse perinatal outcome.

\section{Methods}

We collated data from a large group of singletons and multiples born after PGD between 1995 and 2014. Data on congenital malformation rates in live born children and terminated pregnancies, misdiagnosis rate, birth parameters, perinatal mortality and hospital admissions were prospectively collected by questionnaires.

\section{Results}

439 pregnancies in 381 women resulted in 364 live born children. Nine children (2.5\%) had major malformations. This percentage is consistent with other PGD cohorts and comparable to the prevalence reported by the European Surveillance of Congenital Anomalies (EUROCAT). We reported one misdiagnosis resulting in a spontaneous abortion of a fetus with an unbalanced chromosome pattern. $20 \%$ of the children were born premature (<37weeks) and less than $15 \%$ had a low birth weight. The incidence of hospital admissions is in line with prematurity and low birth weight rate. One child from a twin, one child from a triplet and one singleton died at 23 , 32 and 37 weeks of gestation respectively.

\section{Conclusions}

We found no evidence that PGD treatment increases the risk on congenital malformations or adverse perinatal outcome.

\section{Introduction}

Preimplantation genetic diagnosis (PGD) offers couples at high risk for transmitting a genetic disease to their offspring an alternative to prenatal diagnosis or may enhance their probability of an ongoing pregnancy if one of the parents is carrier of a structural chromosomal abnormality. ${ }^{1}$ Couples opting for PGD have to go through IVF treatment with or without ICSI to obtain embryos for genetic analysis. Blastomeres or trophectoderm (TE) cells for diagnosis are procured through embryo biopsy and analysed by either polymerase chain reaction (PCR), fluorescence in situ hybridization (FISH) or array-comparative genomic hybridization (array-CGH) in order to determine a specific genetic defect or a chromosomal abnormality. ${ }^{2}$

It is hypothesized that assisted reproductive technologies, especially more invasive techniques like ICSI, increase the risk on birth defects. ${ }^{3,4}$ The need for embryo biopsy makes PGD an even more invasive procedure than IVF(-ICSI) treatment alone. Consequently, the safety of PGD is an issue that needs constant scrutinizing, the more since the number of pregnancies after PGD is increasing over the years. ${ }^{5}$ Since the first PGD treatment was performed in the early 1990s, clinical studies on PGD pregnancies and children born after PGD did not report a higher rate of major congenital malformations when compared to IVF-ICSI children. ${ }^{6,7-12}$ The results of these studies raise concerns about adverse perinatal and neonatal outcome, like prematurity rate, the incidence of low and very low birth weight as well as the incidence of perinatal mortality. However, the reported data are derived from only one large and three small cohorts which makes collection of more data desirable. Also, these cohorts mostly contain data on pregnancies and children born after preimplantation genetic screening (PGS), and thus include couples with a history of infertility.

This study presents mostly prospectively collected data concerning the perinatal outcome of all PGD pregnancies in the Netherlands between 1995 and 2014. PGS pregnancies are not included. In view of earlier reported concerns and accompanying importance for patients and health care providers the aim of this study is to establish the safety of PGD in the Netherlands and to contribute to the justification of PGD as a tool in heritable disease prevention. We focus on the congenital malformation rate and additionally report on misdiagnosis, birth parameters and on perinatal mortality and morbidity. 


\section{Methods}

\section{Study subjects}

The study describes results from 439 PGD pregnancies and 366 newborns, originating from all PGD cycles started between 1995 and 2014 in the Netherlands. Two hundred and forty IVF-ICSI treatments were performed in the Maastricht University Medical Centre+ (MUMC+), 161 in the University Medical Centre Utrecht (UMCU), 36 in the University Medical Centre Groningen (UMCG) and two in the Amsterdam Medical Centre (AMC). The latter three IVF departments are PGD transport centers. ${ }^{13}$ All genetic analyses were performed at the department of Clinical Genetics of the MUMC+.

\section{PGD procedure}

Ovarian down-regulation and follicular growth stimulation protocols were performed according to local protocols, as well as the procedures for IVF or ICSI, but they resemble the procedures applied at the MUMC+. ${ }^{14,15}$ On day three after oocyte retrieval and fertilization by IVF (only for FISH analysis) or ICSI one or two blastomeres were removed from cleavage stage embryos for genetic analysis. A laser was used to make a hole in the zona pellucida and replaced the use of acidic Tyrode in the early years of PGD. Blastomeres were analysed using PCR in case of monogenetic or mitochondrial conditions and FISH analysis in case of chromosomal abnormalities. Recently, array-CGH has replaced the FISH technique. Embryos were cultured in individual drops of medium where the development was recorded. On day three or four after oocyte retrieval, one or two unaffected embryos were transferred. ${ }^{16} \mathrm{~A}$ single embryo transfer (SET) policy has been installed by the Dutch government since 2013, though a preference for SET had already been developed since $2006 .{ }^{17}$

\section{Study procedure}

Data on IVF-ICSI treatments and PGD analyses were collected from the medical files in either the clinical genetics department or in the IVF departments of the participating centers. In the first weeks after the birth of their child the parents filled in a comprehensive questionnaire about the pregnancy and the health of their child. They were asked for consent to gather medical information about pregnancy, delivery and the health of their child. Additional data regarding pregnancy, delivery or the newborn were requested from the patient's gynecologist, the observing midwife practice or the treating pediatrician, respectively. The collected data included: age of both parents at embryo transfer, gravidity, parity, number of previous IVF/PGD cycles per couple, whether pregnancy was derived from a fresh or frozen/ thawed embryo, after usage of IVF or ICSI and PCR, FISH or array-CGH for analysis, number of blastomeres biopsied, number of transferred embryos, number of live born children, gender, singleton or multiple, PGD indication, major and minor malformations, still births, pregnancy terminations, misdiagnosis, pre- and postnatal genetic testing, term at delivery, birth weight, perinatal mortality and hospital admissions.

\section{Statistics}

SPSS version 22 (IBM SPSS, Chicago IL) was used for descriptive statistics. The categorical data are presented as proportions. The continuous data are presented as mean and standard deviation. Further, z-scores were calculated for birth weight of all singletons by normalizing the weight of each child using the mean weight with standard deviation of children from a reference population with similar maternal parity, fetal gender, ethnic background and gestational age (Foundation for Perinatal Registration in the Netherlands, 2013).

\section{Definitions}

Congenital malformations are all structural, functional and genetic anomalies diagnosed in aborted fetuses, at birth or in the neonatal period. Minor anomalies are those which do not have serious medical, functional or cosmetic consequences for the child, according to the European Surveillance of Congenital Anomalies. ${ }^{18}$

We used the following ICMART definitions: an ongoing pregnancy is defined as having a pregnancy duration of more than 12 weeks. A miscarriage is defined as the spontaneous loss of a pregnancy before 20 completed weeks of gestational age. A still birth is defined as death before the complete expulsion or extraction from its mother, at or after 20 completed weeks of gestational age. Deliveries before 37 completed weeks of gestation are defined premature and a child is born very premature when delivered before 32 weeks of gestational age. Low birth weight is defined as a birth weight less than 2500 grams and very low birth weight as less than 1500 grams. 
Perinatal mortality denotes fetal or neonatal death during the second term of the pregnancy (after 20 weeks), during delivery or until 7 days after the date of birth. ${ }^{19}$

\section{Literature overview}

We present a table summarizing the data of the Dutch PGD population, the data of other PGD cohorts from literature, as well as the data of a meta-analysis on IVF-ICSI studies.

\section{Ethics}

This study was approved by the local Medical Ethics Committee. Written informed consent was obtained from all participants before their enrolment in the study.

\section{Results}

The characteristics of the couples, treatments and children are shown in Table 3.1. Fifty-three percent of the pregnancies originated from the first PGD cycle. ICSI was used for fertilization in $69 \%$ of the procedures. The distribution between either one or two biopsied blastomeres was equal. Slightly more often one embryo was transferred.

Four hundred and thirty-nine clinical pregnancies resulted in 366 children. Two children were lost to follow-up and excluded from analyses. Thirteen percent of the pregnancies were multiple pregnancies and $28 \%$ of the live born children were part of a twin or triplet. In $85.5 \%$ of the multiple pregnancies, two embryos were transferred. There was a decline in the double embryos transfer rate and the occurrence of multiple pregnancies over time.

The largest proportion of couples (39\%) opted for PGD because of an autosomal dominant (AD) disorder. Huntington disease (12\%), myotonic dystrophy $(6 \%)$ and hereditary breast and ovarian cancer (5\%) were the most common AD conditions. PGD for reciprocal translocations (18\%) was the most requested indication of all and PGD because of a mitochondrial condition the least (0.9\%) (Figure 3.1).

\begin{tabular}{lc} 
Table $3.1 \quad$ Couple, treatment and child characteristics. \\
\hline Mean maternal age (years + SD) & \\
Mean paternal age (years + SD) & $32.3 \pm 3.7$ \\
Number of clinical pregnancies & $35.2 \pm 4.5$ \\
Nulliparous & 439 \\
Cycle order in which pregnancy was achieved & $245 / 439(55.8 \%)$ \\
1 & \\
2 & $234 / 439(53.3 \%)$ \\
3 & $124 / 439(28.2 \%)$ \\
4 & $74 / 439(16.9 \%)$ \\
Pregnancy after transfer of frozen-thawed embryo(s) & $7 / 439(1.6 \%)$ \\
Method of fertilization & $41 / 439(9.3 \%)$ \\
IVF & \\
ICSI & $136 / 439(31.0 \%)$ \\
Genetic analysis technique & $303 / 439(69.0 \%)$ \\
PCR & \\
FISH & $255 / 439(58.1 \%)$ \\
Array-CGH & $181 / 439(41.2 \%)$ \\
Number of blastomeres biopsied per embryo & $3 / 439(0.7 \%)$ \\
1 & \\
2 & $321 / 649(49.5 \%)$ \\
Number of embryos transferred & $328 / 649(50.5 \%)$ \\
1 & $241 / 439(54.9 \%)$ \\
2 & $197 / 439(44.9 \%)$ \\
3 & $1 / 439(0.2 \%)$ \\
Number of children & 364 \\
Boys & $165(45.3 \%)$ \\
Girls & $199(54.7 \%)$ \\
Singleton or multiple & $263(72.3 \%)$ \\
Singleton & $88(24.2 \%)$ \\
Twin & $13(3.6 \%)$ \\
Triplet & \\
\hline
\end{tabular}

${ }^{a}$ Two children were lost to follow-up.

\section{Safety of PGD}

Congenital malformation rate

Major malformations were seen in nine of the 364 live born children (2.5\%) (Table 3.2). Four of these children showed multiple congenital anomalies (MCA): two had a chromosomal abnormality (one singleton had trisomy 21 and one of a twin had trisomy 9 mosaicism), one child presented with an atrial septum defect grade II, an orofacial cleft, and a hydronephrosis and the fourth had an unilateral facial nerve paresis and microtia. The (genetic) cause in the latter two was not found. Three children had a single congenital malformation; a bilateral hydronephrosis, a duodena web, and a hypospadia, respectively. Isolated congenital heart defects were reported 
in two children; one atrial and ventricular septum defect and one atrial septum defect in combination with a pulmonary stenosis.

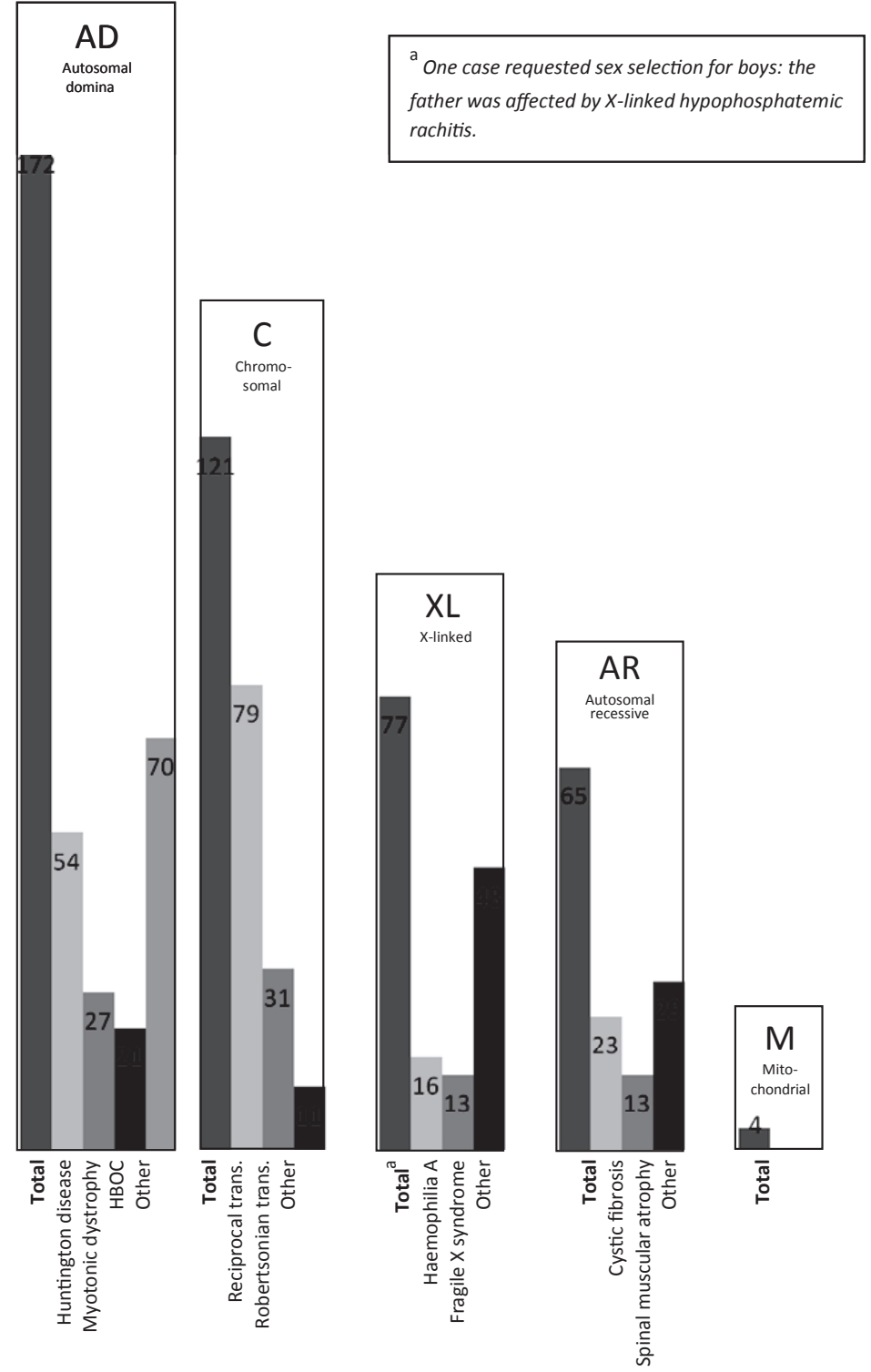

Figure 3.1 Mode of inheritance and most frequent indications in PGD pregnancies $(n=439)$.

\begin{tabular}{|c|c|}
\hline Live born & $N=364^{a}$ \\
\hline Major malformations & $\underline{9(2.5 \%)}$ \\
\hline Multiple malformations & $4(1.1 \%)$ \\
\hline Trisomy 21 & 1 \\
\hline Mosaic trisomy 9 & 1 (one of a twin) \\
\hline ASD, cleft lip, hydronephrosis & 1 \\
\hline Unilateral facial nerve paresis, microtia & 1 \\
\hline Single malformation & $5(1.4 \%)$ \\
\hline Bilateral hydronephrosis & 1 \\
\hline Duodenal web & 1 (one of a twin) \\
\hline Hypospadia & 1 \\
\hline Congenital heart disease & 2 \\
\hline Minor malformations & $5(1.4 \%)$ \\
\hline Sacral dimple & $\frac{1}{2}$ \\
\hline Umbilical hernia & 2 (dizygotic twin) \\
\hline Inguinal hernia & 1 \\
\hline Total & $14(3.8 \%)$ \\
\hline Pregnancies & $N=439$ \\
\hline Still birth & $1(0.2 \%)$ \\
\hline Acardia & 1 (one of a triplet) \\
\hline Pregnancy terminations & $3(0.7 \%)$ \\
\hline Exencephaly & 1 \\
\hline Trisomy 18 & 1 \\
\hline Trisomy 21 & 1 \\
\hline Genetic testing & $\mathrm{N}(\%)$ \\
\hline Non-viable fetus/stillbirth & $\underline{3}$ \\
\hline 8 weeks and 5 days gestational age & 1 (trisomy 16) \\
\hline 8 weeks and 6 days gestational age & 1 (misdiagnosis) $^{24}$ \\
\hline 37 weeks gestational age & 1 (balanced karyotype) \\
\hline Prenatal tests & $26 / 439(5.9 \%)$ \\
\hline Confirmation PGD diagnosis & 9 \\
\hline Abnormalities on ultrasound & 3 (one trisomy 18 , others normal \\
\hline Maternal age & 6 (all normal) \\
\hline Increased risk combined test & 3 (one trisomy 21 , others normal \\
\hline Gender testing XL disorder & 5 (all girls) \\
\hline Postnatal tests in the neonatal period & $16 / 364(4.4 \%)$ \\
\hline Confirmation PGD diagnosis & 13 (all confirmed) \\
\hline
\end{tabular}

${ }^{\mathrm{a}}$ Two children were lost to follow-up and therefore excluded; ${ }^{\mathrm{b}}$ Intra uterine fetal death.

Five children (1.4\%) had a minor malformation. Ultrasound of the neonatal spine in two children with a sacral dimple showed closed vertebrae. Three children presented with a congenital herniation: two twin sisters both had an umbilical hernia and a singleton had an inguinal hernia. The twin sisters were born very premature at $29+3$ weeks gestational age. 
An acardiac fetus was detected in a triplet pregnancy and led to a miscarriage. Three pregnancies were terminated because the fetuses were diagnosed with an exencephaly, trisomy 18 , and trisomy 21 , respectively.

In six pregnancies ultrasound abnormalities were reported which were not confirmed postnatally. Hydronephrosis was diagnosed four times on ultrasound and one girl was suspected to have an abdominal cyst. In one pregnancy the three-vessel view was suspect for a cardiac anomaly, but postnatal follow-up showed none (data not further shown).

\section{Misdiagnosis}

One misdiagnosis is currently known. Chromosomal analysis of a fetus with a negative heart beat on ultrasound showed an unbalanced 47,XX,+der(5)t(X;5)(q13;p14)mat karyotype. The mother was a $46, X, t(X ; 5)(q 13 ; p 14)$ carrier. PGD analysis was done using FISH (Table 3.2).

Genetic testing, either, pre- or postnatal, was performed in $10 \%$ of the pregnancies. In $53 \%$ of the cases the reason for testing was confirmation of the PGD diagnosis, al were confirmed. Other indications were miscarriages, an increased risk for a trisomic fetus and abnormalities on ultrasound suspect for congenital malformations in the newborn.

\section{Birth parameters}

Eighty percent of the children were born at term. Eight children $(2.2 \%)$ were born very premature; all of the latter were from twin pregnancies. (Table 3.3)

Mean birth weight was 3450 grams $( \pm 533)$ for singletons with a mean z-score of 0.17 (reference: Dutch population of newborn children reported by PRN Foundation, 2013). The birth weight of almost half of the children who were part of a twin was considered to be low or very low, as was the birth weight of more than two third of the children who were part of a triplet. Only one singleton had a very low birth weight. This child weighed 1490 grams and was born by selective caesarean section at $35+2$ weeks gestational age, because of Hemolysis, Elevated Liver enzymes Low Platelet - syndrome (HELLP) in the mother.

\section{Perinatal mortality and morbidity}

Perinatal mortality was reported in three pregnancies $(0.8 \%)$. One boy of a twin died at 23 weeks and 4 days gestational age, following the miscarriage of his sibling at
16 weeks gestational age. One of a triplet showed growth retardation on ultrasound and died in utero at 32 weeks gestational age. A singleton was stillborn at 37 weeks gestational age after an uncomplicated pregnancy. Chromosomal analysis of the latte showed a balanced male karyotype and extensive postmortem examination revealed no dysmorphic features or congenital malformations and no cause for his intrauterine death. (Table 3.3)

Hospital admission was required in $18.4 \%$ of the children. The most common reasons for admission were prematurity, (very) low birth weight or a combination of both Other reasons for admission directly after birth were blood glucose level monitoring, hyperbilirubinemia and low body temperature. One girl was admitted a week after birth because of a pyelonephritis. (Table 3.3)

\begin{tabular}{|c|c|c|c|c|}
\hline & Total & Singletons & Twins & Triplets \\
\hline Total & 364 & $263(72.3 \%)$ & $88(24.2 \%)$ & $13(3.6 \%)$ \\
\hline Term (mean in weeks) & 38.6 & 39.2 & 36.3 & 34.1 \\
\hline Premature (<37 weeks) & $63(17.3 \%)$ & $20(7.6 \%)$ & 35 (39.8\%) & $8(61.5 \%)$ \\
\hline Very premature (<32 weeks) & $8(2.2 \%)$ & 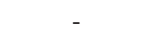 & $8(9.1 \%)$ & \\
\hline Birth weight $^{\mathrm{a}}$ & $N=359$ & $N=262$ & $N=84$ & $N=13$ \\
\hline Median in grams & 3280 & 3462 & 2640 & 1900 \\
\hline Mean in grams (SD) & $3199( \pm 699)$ & $3450( \pm 533)$ & $2554( \pm 610)$ & $2148( \pm 696)$ \\
\hline Mean z-score ${ }^{b}$ & & 0.17 & & \\
\hline Low birth weight (<2500 g) & $52(14.3 \%)$ & $10(3.8 \%)$ & 31 (36.9\%) & $9(69.2 \%)$ \\
\hline Very low birth w. $(<1500 \mathrm{~g})$ & $9(2.5 \%)$ & $1(0.4 \%)$ & $8(9.5 \%)$ & \\
\hline Perinatal mortality & $3(0.7 \%)$ & $1(0.3 \%)$ & $1(0.3 \%)$ & $1(0.3 \%)$ \\
\hline Hospital admission & $67(18.4 \%)$ & $36(9.9 \%)$ & $25(6.9 \%)$ & $8(2.2 \%)$ \\
\hline Low birth weight & $28(7.7 \%)$ & & & \\
\hline$<37$ weeks & $34(9.3 \%)$ & & & \\
\hline
\end{tabular}

${ }^{a}$ data on birth weight were missing of 5 children ${ }^{\mathrm{b}}$ weight of the individual child minus the mean weight of children of mothers being nulliparous or multiparous as well, who have the same gender and ethnical background and were born at the same gestational age within a reference population, divided by standard deviation (PRN Foundation, 2013). References only available for singletons. SD = standard deviation; gr grams; $w$. = weight.

\section{Literature overview}

Some of the data of the Dutch PGD population are presented in Table 3.4 . Additionally, the data of other PGD cohorts that we have found in the literature, as well as the outcomes of a meta-analysis on IVF-ICSI studies are presented in the same table. 


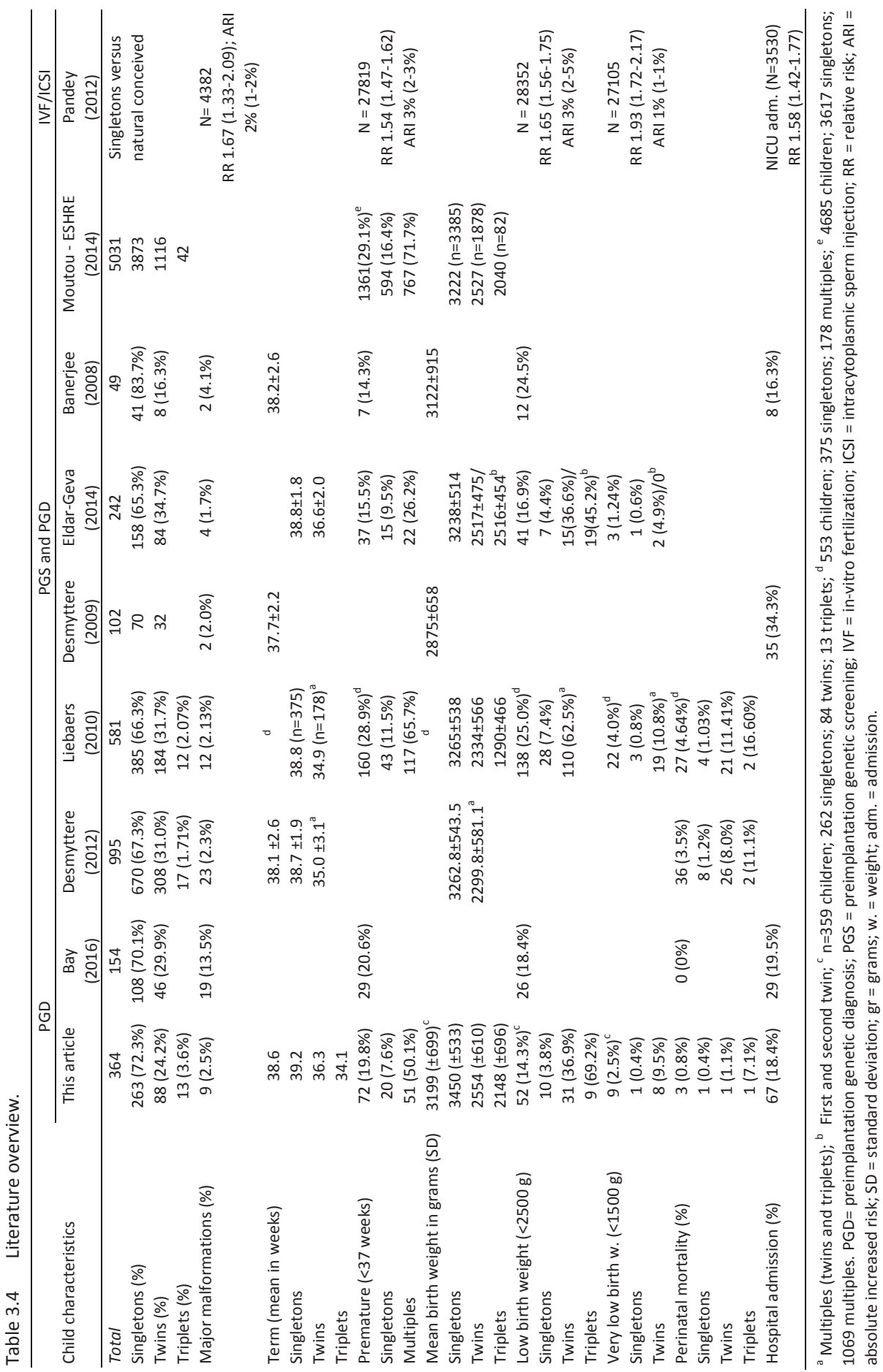

\section{Discussion}

PGD is nowadays a worldwide applied technique for the prevention of genetic disease in offspring. Data on the safety of PGD, namely on congenital malformation rate and adverse perinatal outcome, are mostly reported by one specific PGD center or based on data deduced from a small study population. The main objective of this study was to give an overview of data from a large PGD population in order to provide information on the congenital malformation rate, misdiagnosis rate, birth parameters, perinatal mortality and adverse perinatal outcomes. We report on 364 children and 439 PGD pregnancies. This is data of one of the larger PGD populations published so far.

More girls than boys have been born after PGD treatment, with a ratio of 1.2 for girls. Sex-selection, followed by the transfer of a female embryo, is possible for carrier women of severe X-linked conditions. Corrected for sex-selection in 53 children, a ratio of 1.1 for boys was found, which is in line with the population-based ratio in favor of boys. ${ }^{20}$

The major malformation rate in our group of live born PGD children was $2.5 \%$. When including pregnancy terminations due to congenital malformations, this was $3.3 \%$. Other PGD studies reported a comparable major malformation rate between $1.7 \%$ and $4.1 \%$ in live born children (Table IV) and conclude this to be equal to the risk on major malformations for IVF-ICSI children. In a meta-analysis Pandey et al. stated that the relative risk for congenital anomalies in IVF-ICSI pregnancies is 1.67 (1.33-2.09) when compared to natural conceptions and they report an increase in absolute risk of 2\% (1-2\%). ${ }^{4}$ However, the European Surveillance of Congenital Anomalies reported a prevalence of 261.45 major and minor birth anomalies per 10,000 births $(2.6 \%)$ in the period between 2008 and 2012, which is similar to the prevalence in our PGD cohort. ${ }^{18}$ Overall, the risk on major malformations in children born after PGD seems not increased when compared to the general population. Our study shows similar results.

In four cases (1.1\%) with congenital malformations a chromosomal abnormality was detected. All of these cases involved autosomal chromosomes and were not related to the PGD indication. Of the two trisomy 21 cases, the mothers were aged 31 and 34 , 
the fathers were 31 and 35 years old, were not known to be subfertile and one father did report to be a heavy smoker during the intake interview. The mother, of the fetus with trisomy 18, was 34 years old. Influence of paternal age and smoking habits on aneuploidy is still controversial. ${ }^{21}$ Liebaers et al. reported on one case with a chromosomal abnormality, in their PGD cohort. ${ }^{12}$ Other studies do not report on chromosomal aberrations in their PGD cohort. Bonduelle et al. reported a de-novo chromosomal anomaly rate of $1.6 \%$ in ICSI offspring. ${ }^{22}$ Results of prenatal diagnostic tests in a large group of naturally conceived women aged 35 years and older, showed an incidence of chromosomal abnormalities of $0.9 \%{ }^{23}$ Our results seem to be in line with this, however the mean age of the mothers in this cohort was slightly lower $(32.3 \pm 3.7)$. More evidence is needed before any conclusions on the risk of chromosomal abnormalities can be drawn.

The one misdiagnosis described, was probably due to a technical error. An unbalanced fetal karyotype $47, X X,+\operatorname{der}(5) t(X ; 5)(q 13 ; p 14)$ mat. This case has been extensively reviewed. ${ }^{24}$ Prenatal genetic testing to confirm the PGD diagnosis was offered to all couples, but was performed in only $10 \%$ of the pregnancies. An exact misdiagnosis rate can therefore not be given. Based on our perinatal data we have no indication to expect more misdiagnosis, bearing in mind that manifestations of late-onset diseases are not yet expected. The European Society of Human Reproduction and Embryology PGD consortium reports a misdiagnosis rate of $0.16 \%$, with the annotation that there is a possibility that not all misdiagnosis have been declared by the PGD centers, and this could be an underestimation. ${ }^{25}$ The same consortium evaluated the validity, robustness and diagnostic value of PCR-based PGD. ${ }^{26,27}$ These data seem reassuring when assessing the safety of PGD.

Almost $20 \%$ of the children included in this study were born premature. Less than $15 \%$ of the children had a low birth weight. These were mostly multiples. We calculated a $z$-score of +0.17 for the singletons which indicates a comparable birth weight between our PGD children and the Dutch population. The prematurity rate in the PGD cohorts of Eldar-Geva et al. (15.5\%) and Liebaers et al. (28.9\%) matches with the incidence of low birth weight in their cohorts, which seems to indicate a correlation. ${ }^{11,12}$ All other studies on PGD and PGS show an evident increase in prematurity in multiples when compared to singletons, as does the risk for low and very low birth weight (see for a summary Table 3.4). Our study distinguished very premature children from premature children which shows that the very premature children were all part of a twin. Bay et al. found an increased risk on adverse birth outcomes in PGD children when compared to children born after naturally conceived pregnancies. ${ }^{8}$ The incidence of multiples in their PGD cohort was $30 \%$, compared to an incidence of $3 \%$ in naturally conceived children. Considering the possibly higher perinatal risk for multiples this strongly supports the current SET policy. Since gestational age and birth weight in PGD children are comparable to these parameters in IVF-ICSI children it could be suggested that PGD on itself is not an extra risk factor for adverse perinatal outcome. ${ }^{8,10,28}$

We report one unexplained stillbirth at 37 weeks gestational age. Liebaers et al. reported the perinatal mortality rate to be higher in PGD children (4.64\%) compared to ICSI children. ${ }^{12}$ However, when they stratified for multiples the increased risk of perinatal death in PGD and ICSI singletons was comparable (1.03\%). A meta-analysis by Lamont et al. of cohort and case-control studies describes population based data on 3,412,079 women from high income countries, of whom $24,541(0.7 \%)$ had a stillbirth. ${ }^{29}$ The perinatal mortality rate in our cohort is $0.8 \%$. We found no evidence for a potential increased risk on fetal or neonatal death after PGD.

The incidence of hospital admissions is lower for our PGD children than previously described in PGD cohorts (Table 3.4). These admissions were not associated with the incidence of multiple pregnancies as previously seen in IVF-ICSI cohorts. Explanations for associations found in these latter studies were the higher incidence of preterm birth and low birth weight seen in multiples. There seems to be a relation between the prematurity rate, birth weight and hospital admissions in our PGD cohort since half of the admitted children were born premature.

This study is one of the first large studies on exclusively PGD pregnancies and children. Other studies reported mostly on children born after preimplantation genetic screening (PGS) and completed their cohort with data on children born after PGD. Contrary to PGD, PGS is offered to couples with an IVF-ICSI indication due to infertility and is considered to increase the probability of achieving a pregnancy by excluding aneuploid embryos. ${ }^{30}$ Our prospectively gathered data are rather complete as only two children were lost to follow-up. Our results include data on perinatal events but also pregnancy terminations before the perinatal period, loss of children and congenital malformations in pregnancy. Other studies mostly omitted these latter 
data. This study population consists of all PGD pregnancies in one country and is not restricted to one specific PGD center or area.

In this report the data of the Dutch PGD population were compared to published PGD cohorts, mainly from Belgium, and to published data on naturally conceived pregnancies and children and IVF-ICSI pregnancies and children. A future study on the Dutch PGD population with comparison to Dutch IVF-ICSI and naturally conceived children is desirable. Thereby, the children of the Dutch PGD population were not examined by the research group which could introduce an underestimation of the number of, mainly minor, congenital malformations. As Robins et al. reported that over $40 \%$ of congenital malformations are diagnosed only after one month postpartum. ${ }^{31}$ A follow-up study of older PGD children compared to IVF-ICSI children and naturally conceived children is ongoing.

Overall, the risk on major malformations in PGD children seems comparable to children born after IVF-ICSI as to the risk reported in naturally conceived children. Data on pregnancy duration, birth weight, perinatal mortality and hospital admissions in the Dutch PGD population, especially in the singletons, appear to be similar to the published data on naturally conceived children. In conclusion, PGD does not seem to attribute to an increased risk on an adverse perinatal outcome when compared to naturally conceived children.

\section{References}

1. De Krom G, Arens $\mathrm{YH}$, Coonen $\mathrm{E}$, et al. Recurrent miscarriage in translocation carriers: no difference in clinical characteristics between couples who accept and couples who decline PGD. Hum Reprod. 2015;30(2):484-489.

2. Harton G, Braude P, Lashwood A, et al. ESHRE PGD consortium best practice guidelines for organization of a PGD centre for $\mathrm{PGD} /$ preimplantation genetic screening [published correction appears in Hum Reprod. 2012 Aug;27(8):2569]. Hum Reprod. 2011;26(1):14-24.

3. Davies MJ, Moore VM, Willson KJ, et al. Reproductive technologies and the risk of birth defects. N Engl J Med. 2012;366(19):1803-1813.

4. Pandey S, Shetty A, Hamilton M, Bhattacharya S, Maheshwari A. Obstetric and perinatal outcomes in singleton pregnancies resulting from IVF/ICSI: a systematic review and meta-analysis. Hum Reprod Update. 2012;18(5):485-503.

5. De Rycke M, Belva F, Goossens V, et al. ESHRE PGD Consortium data collection XIII: cycles from January to December 2010 with pregnancy follow-up to October 2011. Hum Reprod. 2015;30(8):1763-1789.

6. Handyside AH, Kontogianni EH, Hardy K, Winston RM. Pregnancies from biopsied huma preimplantation embryos sexed by Y-specific DNA amplification. Nature. 1990;344(6268):768-770.

7. Banerjee I, Shevlin M, Taranissi M, et al. Health of children conceived after preimplantation genetic diagnosis: a preliminary outcome study. Reprod Biomed Online. 2008;16(3):376-381.

8. Bay B, Ingerslev HJ, Lemmen JG, Degn B, Rasmussen IA, Kesmodel US. Preimplantation genetic diagnosis: a national multicenter obstetric and neonatal follow-up study. Fertil Steril. 2016;106(6):1363-1369.e1.

9. Desmyttere S, Bonduelle M, Nekkebroeck J, Roelants M, Liebaers I, De Schepper J. Growth and health outcome of 102 2-year-old children conceived after preimplantation genetic diagnosis or screenine Early Hum Dev. 2009;85(12):755-759.

10. Desmyttere S, De Rycke M, Staessen C, et al. Neonatal follow-up of 995 consecutively born children after embryo biopsy for PGD. Hum Reprod. 2012;27(1):288-293.

11. Eldar-Geva $T$ Srebnik $\mathrm{N}_{\text {altarescu }} \mathrm{G}_{\text {, }}$ et al Neonatal outcome after preimplantation genetic diagnosis. Fertil Steril. 2014;102(4):1016-1021.

12. Liebaers $\mathrm{L}$ Desmyttere $S$, Verpoest $W$, et al. Report on a consecutive series of 581 children born after blastomere biopsy for preimplantation genetic diagnosis. Hum Reprod. 2010;25(1):275-282.

13. Geraedts JP, Harper J, Braude $P$, et al. Preimplantation genetic diagnosis (PGD) a collaborative activity of clinical

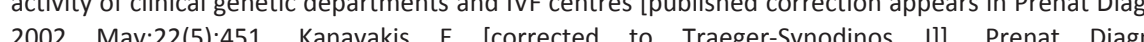

14. Dumoulin JC, Meijers CJ, Bras M, Coonen E, Geraedts JP, Evers JL. Effect of oxygen concentration on human in-vitro fertilization and embryo culture. Hum Reprod. 1999;14(2):465-469.

15. Dumoulin JC, Land JA, Van Montfoort AP, et al. Effect of in vitro culture of human embryos on birthweight of newborns. Hum Reprod. 2010;25(3):605-612.

16. Coonen E, Martini E, Dumoulin JC, et al. Preimplantation genetic diagnosis of a reciprocal translocation t(3;11)(q27.3;q24.3) in siblings. Mol Hum Reprod. 2000;6(3):199-206.

17. van Montfoort AP, Fiddelers AA, Janssen JM, et al. In unselected patients, elective single embryo transfer prevents all multiples, but results in significantly lower pregnancy rates compared with double embryo transfer: a randomized controlled trial. Hum Reprod. 2006;21(2):338-343.

18. European Surveillance of Congenital Anomalies. EUROCAT Guide 1.4 and reference documents. 2013. Available at https://eu-rd-platform.jrc.ec.europa.eu/eurocat_en

19. De Neubourg D, van Duijinhoven NT, Nelen WL. D'Hooghe TM. Dutch translation of the ICMART-WHO revised glossary on ART terminology. Gynecol Obstet Invest. 2012;74(3):233-248.

20. Centraal Bureau voor Statistiek. Geboorte; kerncijfers. 15 sept. 2015 . Available https://opendata.cbs.nl

(1)

tic

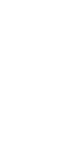


21. Templado C, Uroz L, Estop A. New insights on the origin and relevance of aneuploidy in human spermatozoa. Mol Hum Reprod. 2013;19(10):634-643.

22. Bonduelle $\mathrm{M}$, Van Assche $\mathrm{E}$, Joris $\mathrm{H}$, et al. Prenatal testing in ICSI pregnancies: incidence of chromosomal anomalies in 1586 karyotypes and relation to sperm parameters. Hum Reprod. 2002;17(10):2600-2614.

23. Jacobs PA, Browne C, Gregson N, Joyce C, White H. Estimates of the frequency of chromosome abnormalities detectable in unselected newborns using moderate levels of banding. J Med Genet. 1992;29(2):103-108.

24. Van Echten-Arends J, Coonen E, Reuters B, et al. Preimplantation genetic diagnosis for X;autosome translocations: lessons from a case of misdiagnosis. Hum Reprod. 2013;28(11):3141-3145.

25. Wilton L, Thornhill A, Traeger-Synodinos J, Sermon KD, Harper JC. The causes of misdiagnosis and adverse outcomes in PGD. Hum Reprod. 2009;24(5):1221-1228.

26. Dreesen J, Drüsedau $\mathrm{M}$, Smeets $\mathrm{H}$, et al. Validation of preimplantation genetic diagnosis by $\mathrm{PCR}$ analysis: genotype comparison of the blastomere and corresponding embryo, implications for clinical practice. Mol Hum Reprod. 2008:14(10):573-579.

27. Dreesen J, Destouni A, Kourlaba G, et al. Evaluation of PCR-based preimplantation genetic diagnosis applied to monogenic diseases: a collaborative ESHRE PGD consortium study. Eur I Hum Genet. 2014;22(8):1012-1018.

28. Sunkara SK, Antonisamy B, Selliah HY, Kamath MS. Pre-term birth and low birth weight followin preimplantation genetic diagnosis: analysis of 88010 singleton live births following PGD and IVF cycles. Hum Reprod. 2017;32(2):432-438. Lamont K, Scott NW, Jones GT, Bhattachary

charya S. Risk of recurrent stillbirth: systematic review and sis. BMJ. 2015;350:h3080.

30. Wilton L. Preimplantation genetic diagnosis for aneuploidy screening in early human embryos: a review. Prenat Diagn. 2002;22(6):512-518.

31. Robins J. Congenital Anomalies Surveillance. Review of data relating to congenital anomalies detected in NHS GG\&C between $1^{\text {st }}$ of april 2013 and $31^{\text {st }}$ of march 2014. 18 Oct. 2014.

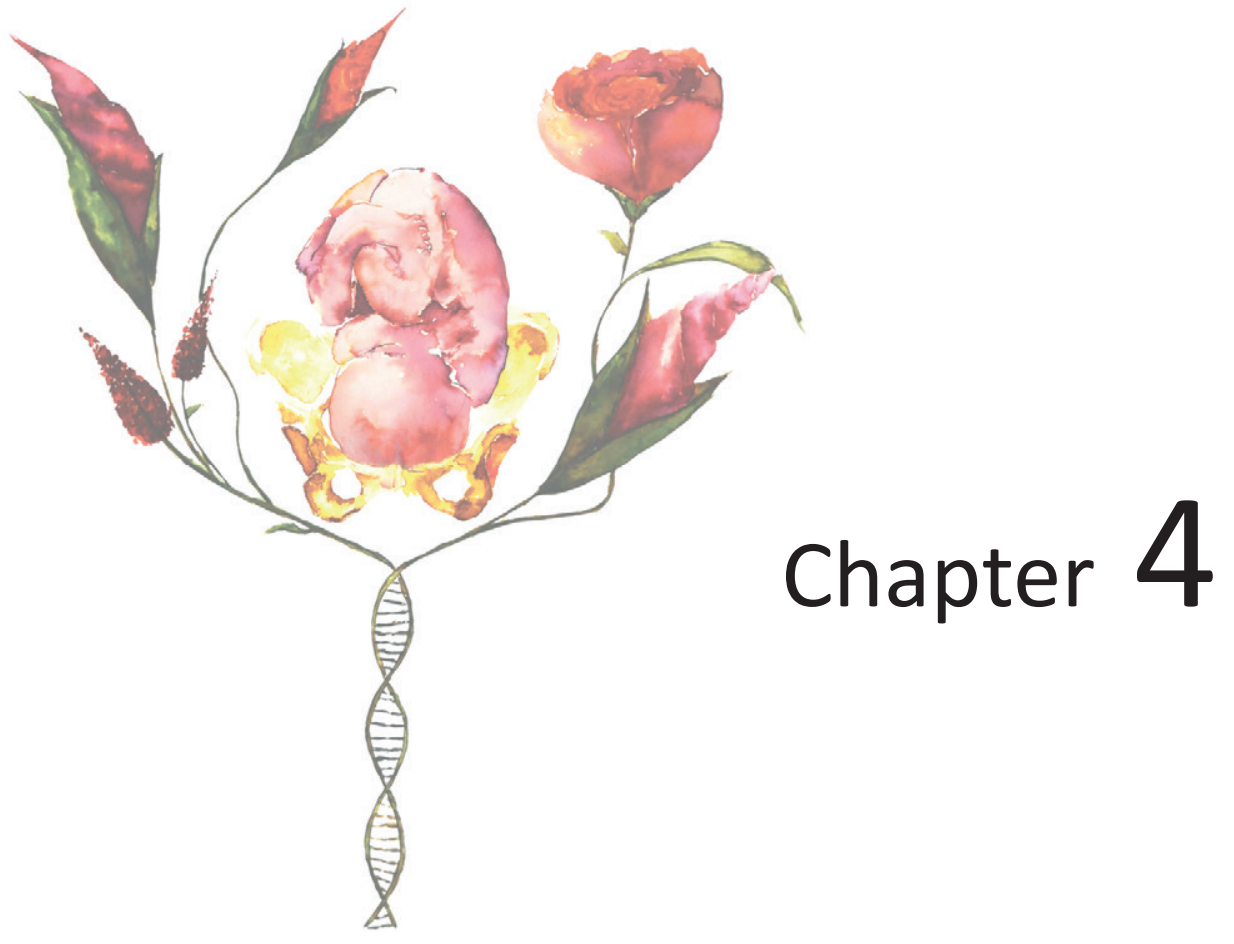

Growth, health and motor development of

5-year-old children born after preimplantation genetic diagnosis

M. Heijligers, A. Peeters, A.P.A. van Montfoort, J. Nijsten, E. Janssen, F. Klein Gunnewiek, R. de Rooy, R. van Golde, E. Coonen, M. Meijer-Hoogeveen, F. Broekmans, M.A.H.B.M. van der Hoeven, Y. Arens, C.E.M. de Die-Smulders 


\section{Abstract}

\section{Objective}

To evaluate the growth, health and motor development of children born after preimplantation genetic diagnosis (PGD).

\section{Design}

Observational cohort study and comparison of 5-year-old children born after PGD to similar aged children born after in-vitro fertilization/intracytoplasmic sperm injection (IVF/ICSI) and children from families with a genetic disorder born after natural conception (NC).

\section{Setting}

University hospital.

\section{Patients}

103 children were included in the PGD group. The two control groups consisted of 90 children born after IVF/ICSI and 58 children born after NC.

\section{Intervention}

PGD

\section{Main outcome measures}

We measured height, weight, body circumferences, BMI and blood pressure and performed a dysmorphological and neurological examination. We also collected data about the children's medical history, health care consultations and motor milestones.

\section{Results}

The mean height, weight and BMI, were comparable for all groups. Six (5.8\%) PGD, four (4.4\%) IVF/ICSI and five (8.6\%) NC children had a major congenital abnormality. The incidence of acute and chronic illnesses was similar in all groups. Motor milestones were achieved on time, but the IVF/ICSI group had a slightly younger mean sitting age. None of the children had severe neurological problems.

\section{Conclusion}

5-year-old children born after PGD show normal growth, health and motor development when compared to children born after IVF/ICSI and NC children from families with a genetic disorder.

\section{Introduction}

Preimplantation genetic diagnosis (PGD) is an assisted reproductive technology (ART) that is used to select embryos without a specific familial genetic disorder. ${ }^{1}$ PGD can be offered to couples at high risk for conceiving a child with a monogenic disorder, a mitochondrial disorder or a chromosomal anomaly..$^{1-3}$ Selecting unaffected embryos requires an in-vitro fertilization (IVF) treatment with or without intracytoplasmic sperm injection (ICSI) followed by genetic testing of one or more biopsied embryonic cells. This biopsy makes PGD a more invasive treatment than most other forms of ART. $^{1-3}$

The health of children born after ART is a frequently discussed topic. ${ }^{4}$ IVF and ICSI coincide with important processes during early embryo development, like epigenetic reprogramming and epigenetic stability. ${ }^{5}$ Embryo biopsy may have an additional effect on these processes. Therefore, it is advisable to evaluate the potential impact of PGD on the congenital abnormality rate, growth, general health and motor development of children born after PGD. We studied the perinatal health of children born after PGD and found no increased risk for congenital abnormalities or adverse perinatal outcome. ${ }^{6}$ However, the health of older children born after PGD has not been studied as intensively yet. Desmyttere et al. studied health and auxological data (outcome measures: weight, height, head, arm and waist circumference) of 2-year-old children born after PGD or preimplantation genetic screening (PGS). ${ }^{7,8}$ Some of these children were also studied at the age of 6 and compared to children born after ICSI. ${ }^{9}$ Banerjee et al. reported on the health, height and weight of ten children born after PGD with a mean age of 18.4 months..$^{10}$ Some studies on the neurological development of children born after PGD and PGS report an increased use of medical diagnostics in these children and question their psychomotor development when compared to children born after natural conception (NC). ${ }^{8,11-14}$

In the underlying study, we compare 5-year-old children born after PGD to similarly aged children born after IVF/ICSI (control group 1) and children from families with a genetic disorder born after NC (control group 2). The first control group was chosen to study the possible effects of the IVF/ICSI treatment, since ICSI is commonly used in PGD to eliminate the contamination risk from extraneous sperm DNA. ${ }^{1,2}$ The second control group was chosen to study the possible effect of the genetic burden in PGD 
families, since this may affect the children's development and behavior. ${ }^{15}$ We hypothesize that the growth, health and motor development of children born after PGD is comparable to that of children born after IVF/ICSI and children born after NC. We aim to give more insight into the possible effects or risks of PGD on children's health, so their parents (or prospective parents), health care providers and other stakeholders will be well informed, and, if necessary, the children will receive special attention or screening advise.

\section{Methods}

\section{Study population}

All Dutch children born after PGD between 2007 and 2013 and their parents were invited to participate once the children reached the age of five years. IVF/ICSI treatment for PGD was performed at either Maastricht University Medical Center+ (MUMC+) or one of its PGD transport-centers (i.e., University Medical Center Utrecht (UMCU) or University Medical Center Groningen (UMCG)).

The children in the IVF/ICSI group were born in the same period as the children in the PGD group and were also invited when they reached the age of five. The IVF/ICSI treatment was performed at MUMC+.

The NC group consisted of children born to parents who had visited the clinical genetics department. They were either recruited from couples who had considered PGD, but eventually declined, or from couples who underwent invasive prenatal testing (chorionic villus sampling or amniocentesis) because of a high risk of transmitting a genetic disorder to their offspring. All children in the NC group were born in the same period as the children in the PGD and IVF/ICSI groups and were also invited once they reached the age of five.

Children were excluded from participation if they were affected with either the familial or an unrelated genetic disorder or if their or their parents' understanding of the Dutch language was insufficient.

\section{Study procedure}

The PGD procedure was performed as described earlier. ${ }^{16-18}$

The children were assessed between January 2014 and July 2018 at either the Department of Clinical Genetics at MUMC+ or the Department of Reproductive Medicine at UMCU.

The first part of the assessment consisted of a semi-structured interview about the child's health, development and birth parameters, and the health and medical history of the parents and any other children. Subsequently, the parents were asked to fill in a comprehensive questionnaire about the child's medical history and their own mental health and education level. Information about the PGD indication, family history and parental carrier status was collected from medical files.

Auxological and physical data about the children were collected according to a standardized protocol. A limited number of trained clinicians performed the examinations. The children's growth and nutritional status were assessed by measuring their height, weight and mid-upper arm circumferences with standard calibrated equipment. ${ }^{19}$ Head and waist circumference were measured using a tape measure. Systolic and diastolic blood pressure were measured using an oscillometric device (OMRON M2, HEM-7121-E).

The physical examination concluded with a dysmorphological and neurological examination that focused on the presence of major or minor congenital abnormalities (or a combination thereof). A major congenital abnormality was defined as a structural, functional or genetic anomaly diagnosed at birth or in the neonatal period. $^{20}$ Minor congenital abnormalities were defined as disturbances of phenogenesis with a prevalence $\leq 4 \%$ or abnormalities as classified by Merks et al. ${ }^{21}$ The neurological examination included observation of the children's resting posture and assessment of their passive muscle tone by determining the resistance of passive movements of the joints of the upper and lower extremities. The tendon reflexes of the patella and biceps were tested and scored as either normal, absent or hyperactive with or without a clonus. The plantar response was tested and scored as normal when the toes contracted downwards. The children's coordination was assessed by executing a finger-to-nose test and a diadochokinetic test (alternating pronation and 
supination of the hands), and by observing the children while standing with closed eyes. Evaluation of the gross motor skills included assessment of their gait width and pattern, the ability to walk on toes and heels, and the ability to stand and hop on one leg.

Finally, all the children underwent neuropsychological tests: the Wechsler Preschool and Primary Scale of Intelligence-III-NL (WPPSI-III-NL) and the Automated Working Memory Assessment battery (AWMA). ${ }^{22-24}$ These neuropsychological data were reported elsewhere. ${ }^{25}$

\section{Statistics}

Data analyses were performed with the IBM Statistical Package for Social Sciences (SPPS) version 23 (IBM SPSS, Chicago IL). P $\leq 0.05$ was considered statistically significant.

A Shapiro-Wilk test was used to test the normality of distribution of continuous data. We used an ANOVA to compare normally distributed metric data between the three. A non-parametric test (Kruskal-Wallis test) was used in case of a skewed distribution. To compare dichotomous outcomes of the three groups, we performed a Chi-square test or a Fisher's exact test. For the major abnormalities and minor abnormalities outcomes, we performed a multiple logistic regression analysis of the groups and possible predictors (i.e., ages of both parents, pregnancy complications, delivery complications, smoking and alcohol/medication use during pregnancy).

\section{Ethics}

The study protocol was approved by the Ethical Committee of Maastricht University and the University Hospital Maastricht (NL43048.068.13 / METC 13-2-010). Informed written consent was obtained from all parents prior to the examination.

\section{Results}

In total, we invited 185 children born after PGD to participate in the study, of whom 103 children (55.7\%) participated. Eighteen of those 103 children were twins. We invited 268 children born after IVF/ICSI to participate in this study, of whom 90 children (33.6\%) participated. Four of those 90 children were twins. Of the 217 children that we invited for the NC group, 58 children (26.7\%) participated in the study; none of them were twins. One child was not invited to participate in the PGD group because of partial biotinidase deficiency (not related to the PGD indication). Ten children were not invited to participate in the NC group because they were affected with the familial genetic disorder (cystic fibrosis, nail-patella syndrome, congenital disorder of glycosylation type 1c, Marfan syndrome, Waardenburg syndrome, neurofibromatosis type 2, Aicardi Goutières syndrome and familial adenomatous polyposis) or another genetic disorder (1q21 duplication syndrome). All eligible children for the IVF/ICSI group were invited to participate.

Table 4.1 summarizes the baseline characteristics of the participating children and their parents. The three groups of children were comparable with respect to male/female ratio, child's mean age at assessment, gestational age, birth weight and birth order. The parental education level, maternal BMI and alcohol consumption during pregnancy were also comparable.

There was a significant age difference between the mothers $(P=0.015)$ and fathers $(P=0.019)$ in the three groups. On average, PGD parents were the youngest. There was also significant difference in the number of mothers who smoked during pregnancy ( $P=0.002$; more mothers in the IVF/ICSI group smoked), and the father's BM $(P<0.0001$; those in the PGD group had the highest BMI). Two fathers in the PGD group had morbid obesity (BMIs of 40.91 and 42.90 , respectively).

Significantly more children in the PGD group than in the NC group $(P=0.001)$ had a living affected first-degree family member (parent or sibling) or first-degree family member at risk for a late onset disorder. Additional information about the specific genetic disorders and the number of participating children compared to children who did not participate is given in the supplementary data (Supplementary Table S4.1). 
Table 4.1 Baseline characteristics of children and parents.

\begin{tabular}{|c|c|c|c|c|}
\hline & $\begin{array}{c}\text { PGD } \\
(n=103)\end{array}$ & $\begin{array}{c}\text { IVF/ICSI } \\
(n=90)\end{array}$ & $\begin{array}{c}\mathrm{NC} \\
(n=58)\end{array}$ & $P$-value \\
\hline Gender & & & & 0.44 \\
\hline Male & $54(52.4 \%)$ & $40(44.4 \%)$ & $31(53.4 \%)$ & \\
\hline Female & 49 (47.6\%) & $50(55.6 \%)$ & $27(46.6 \%)$ & \\
\hline Age at assessment (years) & $5.44 \pm 0.24$ & $5.38 \pm 0.22$ & $5.47 \pm 0.29$ & 0.16 \\
\hline Gestational age (weeks) & $38.77 \pm 2.25$ & $38.89 \pm 2.31$ & $39.38 \pm 1.28$ & 0.614 \\
\hline Birth weight (g) & $\begin{array}{c}3361.12 \pm 666.68 \\
\quad(n=101)\end{array}$ & $\begin{array}{c}3300.72 \pm 624.44 \\
(n=90)\end{array}$ & $\begin{array}{c}3440.14 \pm 435.72 \\
(n=57)\end{array}$ & 0.555 \\
\hline Birth order & & & & 0.28 \\
\hline $1^{\text {st }}$ & $56(54.4 \%)$ & $54(60.0 \%)$ & $25(43.1 \%)$ & \\
\hline $2^{\text {nd }}$ & $33(32.0 \%)$ & $20(22.2 \%)$ & $23(39.7 \%)$ & \\
\hline $3^{\text {rd }}$ & $109.7 \%)$ & $12(13.3 \%)$ & $5(8.6 \%)$ & \\
\hline $4^{\text {th }}$ & $4(3.9 \%)$ & $3(3.3 \%)$ & $4(6.9 \%)$ & \\
\hline $5^{\text {th }}$ & 0 & $1(1.1 \%)$ & $1(1.7 \%)$ & \\
\hline Maternal age at birth (years) & $32.6 \pm 3.2$ & $33.9 \pm 3.5$ & $34.0 \pm 4.4$ & 0.015 \\
\hline Maternal education level & & & & 0.43 \\
\hline Low & 44 (44.9\%) & $44(50.6 \%)$ & $19(34.5 \%)$ & \\
\hline Medium & $38(38.8 \%)$ & $32(36.8 \%)$ & $27(49.1 \%)$ & \\
\hline High & $16(16.3 \%)$ & $11(12.6 \%)$ & $9(16.4 \%)$ & \\
\hline Maternal BMI $\left(\mathrm{kg} / \mathrm{m}^{2}\right)$ & $\begin{array}{c}24.9 \pm 4.3 \\
(n=102)\end{array}$ & $\begin{array}{c}24.4 \pm 4.0 \\
(n=90)\end{array}$ & $\begin{array}{c}23.6 \pm 3.1 \\
(n=57)\end{array}$ & 0.25 \\
\hline Smoking during pregnancy & $3 / 103(2.9 \%)$ & 10/90 (11.1\%) & $0 / 58(0 \%)$ & 0.002 \\
\hline Alcohol during pregnancy & $2 / 103(1.9 \%)$ & $2 / 90(2.2 \%)$ & $5 / 58(8.6 \%)$ & 0.100 \\
\hline Paternal age at birth (years) & $35.6 \pm 3.7$ & $38.1 \pm 6.3$ & $36.0 \pm 5.1$ & 0.019 \\
\hline Paternal education level & & & & 0.46 \\
\hline Low & 40 (43.0\%) & $38(48.7 \%)$ & $20(41.7 \%)$ & \\
\hline Medium & $40(43.0 \%)$ & $28(35.9 \%)$ & $16(33.3 \%)$ & \\
\hline High & $13(14.0 \%)$ & $12(15.4 \%)$ & $12(25.0 \%)$ & \\
\hline Paternal BMI $\left(\mathrm{kg} / \mathrm{m}^{2}\right)$ & $\begin{array}{c}26.6 \pm 3.8 \\
(n=101)\end{array}$ & $\begin{array}{c}25.3 \pm 3.5 \\
(n=89)\end{array}$ & $\begin{array}{c}24.6 \pm 3.0 \\
(n=58)\end{array}$ & $<0.0001$ \\
\hline Genetic family characteristics & & & & 0.001 \\
\hline Affected living $1^{\text {st }}$ degree family member & $48(46.6 \%)$ & & $10(17.2 \%)$ & \\
\hline Deceased sibling & $8(7.8 \%)$ & & $10(17.2 \%)$ & \\
\hline No affected $1^{\text {st }}$ degree family member & $47(45.6 \%)$ & & $38(65.5 \%)$ & \\
\hline
\end{tabular}

Table 4.2 provides data about the children's growth. We found no significant difference between the three groups for any of the outcome measurements. The children in the PGD group tended to be somewhat taller, though not significantly so, than the children in the two control groups $(P=0.15)$, and they also had the highest mean weight and largest head circumference. More precisely, the differences in mean height and head circumference were less than $0.5 \mathrm{~cm}$ and $1.5 \mathrm{~cm}$, respectively, and the difference in mean weight was less than $0.5 \mathrm{~kg}$. The mean BMI was similar $\left(15.2 \mathrm{~kg} / \mathrm{m}^{2}\right)$ for all three groups and considered normal. Also, we found no differences in the mean arm and waist circumferences of the study and control groups.

Table 4.2 Growth parameters and body circumferences.

\begin{tabular}{lcccc}
\hline & $\begin{array}{c}\text { PGD } \\
(\mathrm{n}=103)\end{array}$ & $\begin{array}{c}\text { IVF/ICSI } \\
(\mathrm{n}=90)\end{array}$ & $\begin{array}{c}\mathrm{NC} \\
(\mathrm{n}=58)\end{array}$ & $P$-value \\
\hline Length $(\mathrm{cm})$ & $114.96 \pm 5.41$ & $113.56 \pm 4.38$ & $114.33 \pm 4.86$ & 0.15 \\
Weight $(\mathrm{kg})$ & $20.1 \pm 2.7(\mathrm{n}=102)$ & $19.7 \pm 2.7(\mathrm{n}=90)$ & $19.9 \pm 2.2(\mathrm{n}=58)$ & 0.34 \\
BMI $\left(\mathrm{kg} / \mathrm{m}^{2}\right)$ & $15.2 \pm 1.2(\mathrm{n}=102)$ & $15.2 \pm 1.4(\mathrm{n}=90)$ & $15.2 \pm 1.1(\mathrm{n}=58)$ & 0.79 \\
Head circumference $(\mathrm{cm})$ & $51.6 \pm 1.4$ & $51.2 \pm 1.4$ & $51.4 \pm 1.6$ & 0.13 \\
Arm circumference $(\mathrm{cm})$ & $17.8 \pm 1.3(\mathrm{n}=102)$ & $17.7 \pm 1.7(\mathrm{n}=89)$ & $17.8 \pm 1.1(\mathrm{n}=58)$ & 0.49 \\
Waist circumference $(\mathrm{cm})$ & $54.8 \pm 3.5(\mathrm{n}=101)$ & $54.5 \pm 3.5(\mathrm{n}=89)$ & $54.6 \pm 3.2(\mathrm{n}=57)$ & 0.84 \\
\hline
\end{tabular}

Table 4.3 provides several parameters about the children's health. Six children (5.8\%) in the PGD group had a major congenital abnormality, which was comparable $(P=0.59)$ to the incidence of major congenital abnormalities in the IVF/ICSI (4.4\%) and NC (8.6\%) groups. We found no relationship between major and minor congenital abnormalities. The results of logistic regression analysis for major and minor abnormalities showed no significant relationships with predictors. The difference between the three groups remained insignificant. Mean blood pressure values were comparable for all three groups. The majority of the children (82.5-90.0\%) had experienced an acute illness during their life for which they were seen by a general practitioner or in the emergency department. Most of the acute consultations were because of acute wounds or high fever. Some children suffered from chronic illness (most commonly gastrointestinal problems and allergies), but the incidence was comparable in all three groups. The most frequently consulted medical specialists were pediatricians and ear-nose-throat specialists. An equal number of children in al three groups had hospital admissions in their medical history with a comparable duration. Almost half of the children had been seen by allied health professionals, mostly physical therapists or speech therapists.

Table 4.4 shows the results of the assessment of the children's motor development. A substantial part of the parents found it difficult to recall the age at which the children were able to sit and started to talk, so that data might be less reliable. Based on the available data, the mean sitting age differed $(P=0.04)$ among the groups. The children in the IVF/ICSI group were able to sit independently less than one month earlier than the PGD and NC groups. The mean walking age and mean age at which the children 
spoke their first word were comparable among the groups. The vast majority ( $>90 \%$ ) of the children had normal neurological examinations (i.e., they performed all the exercises and tests as expected for their age). The other $10 \%$ of children scored below normal due to difficulties with standing or hopping on one leg or because tendon reflexes could not be evoked. However, none of the children had severe neurological abnormalities.

Table 4.3 Health of the children

\begin{tabular}{lcccc}
\hline & $\mathrm{PGD}(\mathrm{n}=103)$ & IVF/ICSI $(\mathrm{n}=90)$ & $\mathrm{NC}(\mathrm{n}=58)$ & $P$-value \\
\hline Major abnormality & $6 / 103(5.8 \%)^{\ddagger}$ & $4 / 90(4.4 \%)^{*}$ & $5 / 58(8.6 \%)^{\mu}$ & 0.59 \\
3 or more minor abnormalities & $13 / 103(12.6 \%)$ & $15 / 90(16.7 \%)$ & $5 / 58(8.6 \%)$ & 0.35 \\
Systolic blood pressure $(\mathrm{mmHg})$ & $96.8 \pm 11.8(\mathrm{n}=98)$ & $96.2 \pm 13.0(\mathrm{n}=83)$ & $95.6 \pm 10.2(\mathrm{n}=58)$ & 0.60 \\
Diastolic blood pressure (mmHg) & $59.2 \pm 13.4(\mathrm{n}=98)$ & $59.1 \pm 16.5(\mathrm{n}=83)$ & $55.6 \pm 9.6(\mathrm{n}=58)$ & 0.40 \\
Acute illness & $86 / 100(86.0 \%)$ & $81 / 90(90.0 \%)$ & $47 / 57(82.5 \%)$ & 0.41 \\
Chronic illness & $43 / 100(43.0 \%)$ & $34 / 90(37.8 \%)$ & $15 / 57(26.3 \%)$ & 0.11 \\
Medical specialist consultation & $60 / 100(60.0 \%)$ & $48 / 90(53.3 \%)$ & $33 / 57(57.9 \%)$ & 0.65 \\
Hospital admission & $19 / 99(19.2 \%)$ & $24 / 90(26.7 \%)$ & $16 / 57(28.1 \%)$ & 0.34 \\
Admission duration (days) & $4.4 \pm 7.0(\mathrm{n}=19)$ & $7.2 \pm 15.6(\mathrm{n}=24)$ & $5.8 \pm 5.1(\mathrm{n}=16)$ & 0.13 \\
Paramedics consultation & $45 / 100(45.0 \%)$ & $38 / 90(42.2 \%)$ & $23 / 57(40.4 \%)$ & 0.84 \\
\hline
\end{tabular}

\begin{tabular}{lcccc} 
Paramedics consultation & $45 / 100(45.0 \%)$ & $38 / 90(42.2 \%)$ & $23 / 57(40.4 \%)$ & 0.84 \\
\hline F Inguinal herniation $(n=2)$, congenital heart defect $(n=2)$, umbilical herniation; ¥ Hydroneprhosis, cleft
\end{tabular} palate, inguinal herniation, cryptorchidism; $\mu$ Congenital heart defect $(n=2)$, hypospadia, inguina herniation; § As classified by Merks et al. ${ }^{2}$

Table 4.4 Motor development

\begin{tabular}{lcccc}
\hline & $\mathrm{PGD}(\mathrm{n}=103)$ & $\mathrm{IVF} / \mathrm{ICSI}(\mathrm{n}=90)$ & $\mathrm{NC}(\mathrm{n}=58)$ & $P$-value \\
\hline Mean sitting age (months) & $7.7 \pm 2.0(\mathrm{n}=81)$ & $7.1 \pm 1.5(\mathrm{n}=69)$ & $7.9 \pm 2.0(\mathrm{n}=47)$ & 0.04 \\
Mean walking age (months) & $14.7 \pm 3.3(\mathrm{n}=95)$ & $13.8 \pm 2.4(\mathrm{n}=84)$ & $13.8 \pm 2.2(\mathrm{n}=54)$ & 0.11 \\
Mean age first word (months) & $11.7 \pm 3.9(\mathrm{n}=72)$ & $11.0 \pm 3.0(\mathrm{n}=64)$ & $11.4 \pm 4.4(\mathrm{n}=47)$ & 0.70 \\
Normal neurological examination $(\mathrm{n} / \mathrm{N})$ & $95 / 102(93.1 \%)$ & $84 / 88(95.5 \%)$ & $56 / 58(96.6 \%)$ & 0.60 \\
\hline
\end{tabular}

\section{Discussion}

Based on our results children born after PGD seem to have normal growth, health and motor development when compared to children born after IVF/ICSI and children from families with a genetic disorder born after NC.

We found that the growth parameters in 5-year-old children born after PGD were comparable to those of similar aged children born after IVF/ICSI and naturally conceived children from families with a genetic disorder. A study of 6-year-old children born after PGD showed no difference in BMI when compared to children born after ICSI. ${ }^{9}$ However, an earlier study of the same research group of 2-year-old children born after PGD and PGS found that they had slightly lower BMIs than children born after NC. ${ }^{8}$ Another study reported that lower birth weight and prematurity are more common in children born after PGD/PGS than in children born after $\mathrm{NC}^{10}{ }^{10}$ Both studies included more children born after PGS than after PGD $(60 \%$ and $80 \%$ born after PGS, respectively) making it difficult to assess whether the biopsy or the intrinsic parental characteristics causes the lower weights.

Low birth weight is common in children born after IVF/ICSI and is often followed by catch-up growth during late infancy. Such catch-up growth is associated with raised blood pressures and a higher risk for disorders like diabetes mellitus type 2, obesity and cardiovascular disease later in life. ${ }^{26-28}$ Also, several studies on mice born after blastomere biopsy found increased body weight and size at an older age and concluded that this increases the risk of cardiovascular and metabolic disease. ${ }^{29}$ In our study, the PGD treatment had no adverse effect on the growth of 5-year-old children. At this moment, however, there are no data to study a possible adverse effect of PGD on growth, in particular BMI, in older children. Further follow-up is necessary to address this topic.

We found no indication that children born after PGD suffer any adverse health effects caused by the treatment. This contradicts the Developmental Origin of Health and Disease hypothesis, which states that exposure to a stressful environment during early pregnancy, and maybe even during the preimplantation period, increases the risk of a variety of diseases later in life. ${ }^{30,31}$ Desmyttere et al. may have seen an early effect of the embryo biopsy, and thus a possible stressful environment, on health, since they reported that children born after PGD/PGS receive more complementary medical examinations than children born after IVF/ICSI or NC. ${ }^{8}$ Studies on mice born after blastomere biopsy also report an adverse stress response which can influence growth and health later in life. ${ }^{29,32}$ However, Desmyttere et al. stated that the increased medical interventions could also be interpreted as precautionary measures in children who were specially conceived. ${ }^{8}$ Overall, 5 -year-old children born after PGD seem to be healthy, but we advise that their health later in life be evaluated since the risk of cardiovascular and metabolic disease has not been studied. 
Our results about the motor development of 5 -year-old children born after PGD support previously published results on the cognitive and socio-emotional development of children born after PGD. ${ }^{14,25}$ However, our results are inconsistent with other published studies that found lower motor development scores for children born after PGS, and thus with embryo biopsy, than for children born after IVF. ${ }^{12,13}$ One difference between PGD and PGS families is that some of the parents in the PGD families are affected with a genetic disorder and thus have a somatic illness. Having a somatically ill parent can cause regression of recently acquired skills. ${ }^{15,25}$ Reasoning further, one would expect to find worse motor development in children born after PGD than in children born after IVF, rather than lower motor development scores in children born after PGS than in children born after IVF. In this study, some of the children in the PGD and the NC groups had a somatically ill parent, but we could not confirm that the parental illness affected the children's motor development. It is not known why PGS children have less favorable results for motor development. Our results, in combination with earlier published results on children born after PGD, suggest that it is unlikely that the PGD procedure, especially the embryo biopsy, has an adverse effect on the children's development.

The strength of our study is the inclusion of a relatively large group of children born solely after PGD, and not a combination of PGD and PGS. Furthermore, we are the first to assess the growth, health and motor development of such children at an older age and to compare them to children born after NC. Choosing a control group of naturally conceived children from families with a genetic disorder is unique and gave us the opportunity to study the possible influences of the genetic burden on the children's development. Unfortunately, the response rates and the absolute numbers in the IVF/ICSI and NC group were lower than in the PGD group. The difference in response rate might be due to the fact that the parents of the children born after PGD had a higher affinity with the research question than the parents in the other two groups. Given the unequal response rate, some results, particularly regarding motor development might be biased. Children with a somatically ill parent may show developmental regression. An underrepresentation of such children in the NC group (Supplementary table I) might lead to an overestimation of the 'normal' score in this group. However, this would strengthen our result that children born after PGD do not have an increased risk of decreased motor development.
In conclusion, the results of this study suggest that children born after PGD have normal growth and motor development and have no increased risk of health problems in the first years of life. This study contributes to the knowledge about the growth, health and motor development of children born after PGD. Still, because adverse growth during childhood can increase the risk of cardiovascular disease later in life, there is a need for long-term follow-up that evaluate these children's growth and health. 


\section{References}

1. Sermon K, Van Steirteghem A, Liebaers I. Preimplantation genetic diagnosis. Lancet. 2004;363(9421):1633-1641

2. Harton G, Braude P, Lashwood A, et al. ESHRE PGD consortium best practice guidelines for organization of a PGD centre for PGD/preimplantation genetic screening [published correction appears in Hum Reprod. 2012 Aug;27(8):2569]. Hum Reprod. 2011;26(1):14-24.

3. Harton GL, Harper JC, Coonen E, et al. ESHRE PGD consortium best practice guidelines for fluorescence in situ hybridization-based PGD. Hum Reprod. 2011;26(1):25-32.

4. Chen M, Heilbronn LK. The health outcomes of human offspring conceived by assisted reproductive technologies (ART). J Dev Orig Health Dis. 2017;8(4):388-402.

5. Jiang Z, Wang $Y$, Lin J, Xu J, Ding G, Huang H. Genetic and epigenetic risks of assisted reproduction. Best Pract Res Clin Obstet Gynaecol. 2017;44:90-104.

6. Heijligers M, van Montfoort A, Meijer-Hoogeveen M, et al. Perinatal follow-up of children born after 2002.

7. Desmyttere S, Bonduelle M, Nekkebroeck J, Roelants M, Liebaers I, De Schepper J. Growth and health outcome of 102 2-year-old children conceived after preimplantation genetic diagnosis or screenin Early Hum Dev. 2009;85(12):755-759.

8. Desmyttere S, De Schepper J, Nekkebroeck J, et al. Two-year auxological and medical outcome of singletons born after embryo biopsy applied in preimplantation genetic diagnosis or preimplantation genetic screening. Hum Reprod. 2009;24(2):470-476,

9. Belva F, Roelants M, Kluijfhout S, et al. Body composition and blood pressure in 6-year-old singletons born after pre-implantation genetic testing for monogenic and structural chromosomal aberrations: matched cohort study. Hum Reprod Open. 2018;2018(4):hoy013. Published 2018 Sep 1.

10. Baneriee I, Shevlin M, Taranissi M, et al. Health of children conceived after preimplantation genetic diagnosis: a preliminary outcome study. Reprod Biomed Online. 2008;16(3):376-381.

11. Middelburg KJ, Heineman MJ, Haadsma ML, Bos AF, Kok JH, Hadders-Algra M. Neurological condition of infants born after in vitro fertilization with preimplantation senetic screening Pediatr Res. 2010;67(4):430-434

12. Middelburg KJ, van de outcomes of 2-year-old children born after preimplantation genetic screening: follow-up of a

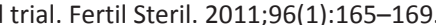

13. Schendelaar P, Middelburg KJ, Bos AF, et al. The effect of preimplantation genetic screening on neurological, cognitive and behavioural development in 4-year-old children: follow-up of a RCT. Hum Reprod. 2013;28(6):1508-1518.

14. Winter C, Van Acker F, Bonduelle M, Desmyttere S, De Schrijver F, Nekkebroeck J. Cognitive and psychomotor development of 5- to 6-year-old singletons born after PGD: a prospective casecontrolled matched study. Hum Reprod. 2014;29(9):1968-1977.

15. Romer, G., Barkmann, C., Schulte-Markwort, M., Thomalla, G., \& Riedesser, P. (2002). Children of Somatically III Parents: A Methodological Review. Clinical Child Psychology and Psychiatry, 7(1), 17-38.

16. Dumoulin JC, Meijers CJ, Bras M, Coonen E, Geraedts JP, Evers JL. Effect of oxygen concentration on human in-vitro fertilization and embryo culture. Hum Reprod. 1999;14(2):465-469.

17. Dumoulin JC, Land JA, Van Montfoort AP, et al. Effect of in vitro culture of human embryos on birthweight of newborns. Hum Reprod. 2010;25(3):605-612.

18. Coonen E, Martini E, Dumoulin JC, et al. Preimplantation genetic diagnosis of a reciprocal translocation $\mathrm{t}(3 ; 11)(\mathrm{q} 27.3 ; \mathrm{q} 24.3)$ in siblings. Mol Hum Reprod. 2000;6(3):199-206.

19. Gripp KW, Slavotinek AM, Hall JG, Allanson JE. Handbook of physical measurements. 3rd ed. Oxford University Press Inc., 2013

20. European Surveillance of Congenital Anomalies. EUROCAT Guide 1.4 and reference documents, 2013. Available at: http://www.eurocat-network.eu.
21. Merks JH, van Karnebeek CD, Caron HN, Hennekam RC. Phenotypic abnormalities: terminology and classification. Am J Med Genet A. 2003;123A(3):211-230.

22. Wechsler D. Wechsler Preschool and Primary Scale of Intelligence III. Amsterdam: NCS Pearson, 2009. 3. Hendriksen J, Hurks P. WPPSI-III-NL. Wechsler Preschool and Primary Scale of Intelligence - Third Edition. Nederlandstalige bewerking. Afname- en scoringshandleiding. Amsterdam: Pearson, 2010.

24. Alloway TP. Automated Working Memory Assessment Manual. London: Pearson Education, 2007.

25. Heijligers $M$, Verheijden $L M M$, Jonkman $L M$, et al. The cognitive and socio-emotional development of 5-year-old children born after PGD. Hum Reprod. 2018;33(11):2150-2157.

26. Bay B, Mortensen EL, Kesmodel US. Is subfertility or fertility treatment associated with long-term growth in the offspring? A cohort study. Fertil Steril. 2014;102(4):1117-1123.

27. Ceelen $\mathrm{M}$, van Weissenbruch MM, Prein J, et al. Growth during infancy and early childhood in relation to blood pressure and body fat measures at age 8-18 years of IVF children and spontaneously conceived controls born to subfertile parents. Hum Reprod. 2009;24(11):2788-2795.

28. Guo XY, Liu XM, Jin L, et al. Cardiovascular and metabolic profiles of offspring conceived by assisted reproductive 631.e5

29. Zacchini F, Arena R, Abramik A, Ptak GE. Embryo biopsy and development: the known and the unknown. Reproduction. 2017;154(5):R143-R148.

30. Barker DJ. The origins of the developmental origins theory. J Intern Med. 2007;261(5):412-417.

31. Feuer S, Rinaudo P. Preimplantation stress and development. Birth Defects Res $C$ Embryo Today. 2012;96(4):299-314.

32. Zeng $Y$, Lv Z, Gu L, et al. Preimplantation genetic diagnosis (PGD) influences adrenal development and response to cold stress in resulting mice. Cell Tissue Res. 2013;354(3):729-741. 
Supplemental material

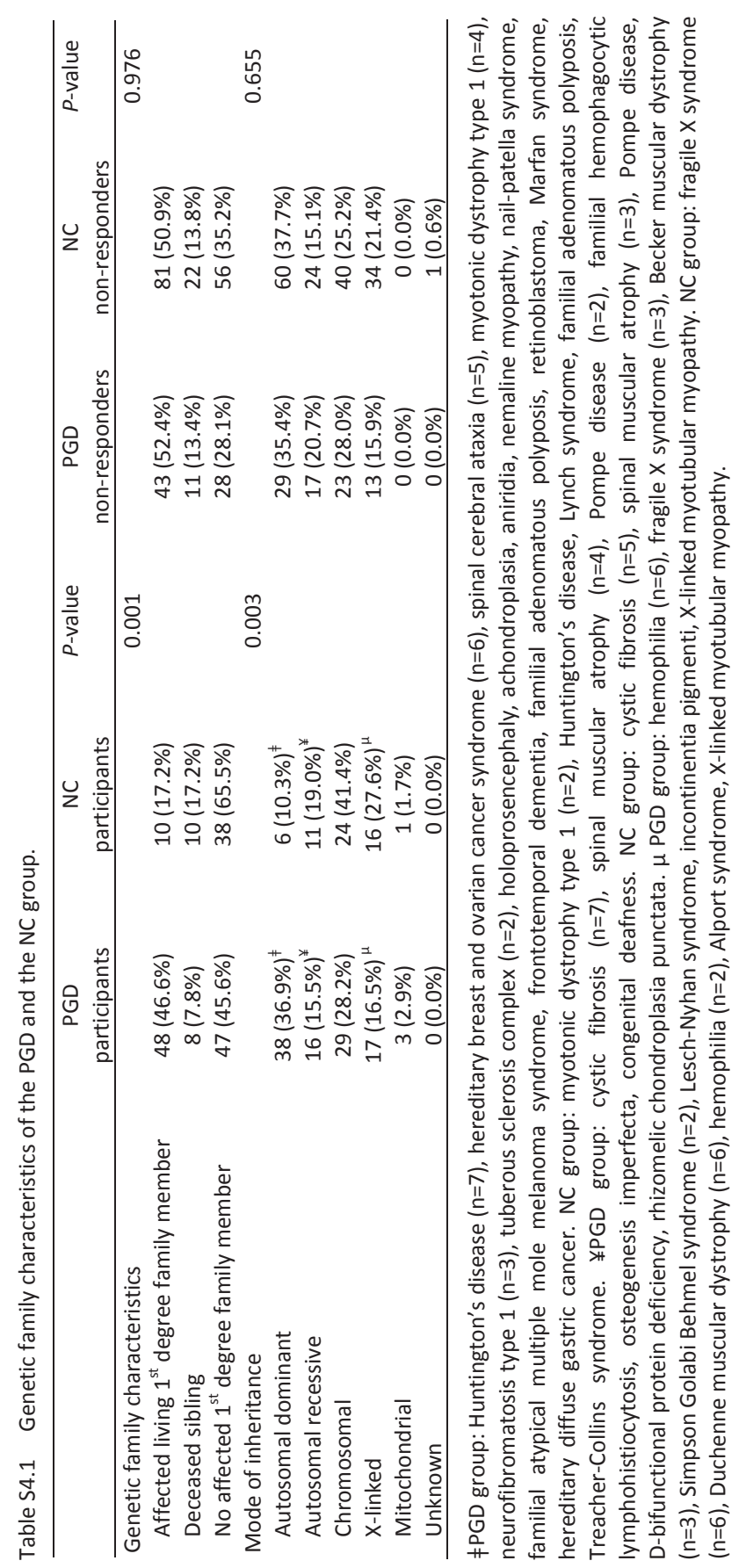

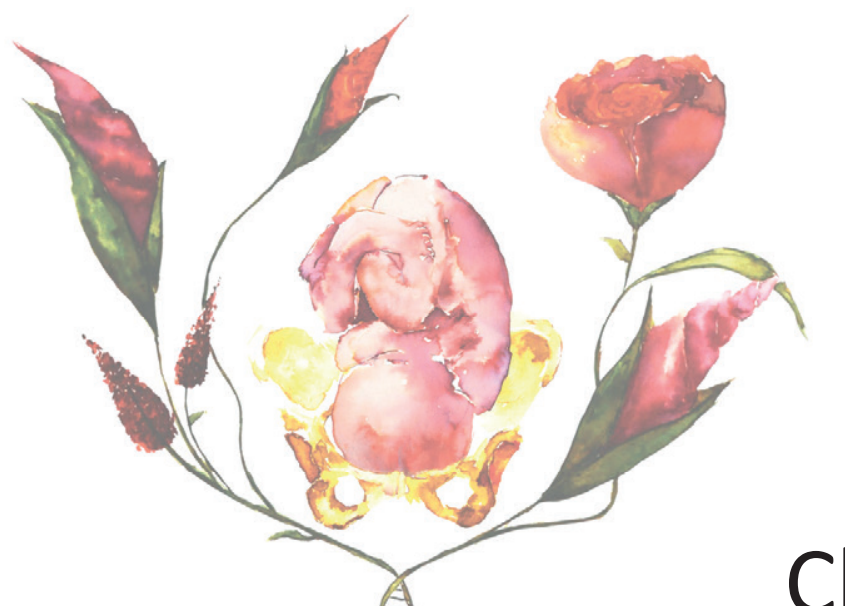

Chapter 5

The cognitive and socio-emotional development of

5-year-old children born after preimplantation

genetic diagnosis

M. Heijligers ${ }^{\dagger}$, L.M.M. Verheijden ${ }^{\dagger}$, L.M. Jonkman, M. van der Sangen, M. MeijerHoogeveen, Y. Arens, M.A. van der Hoeven, and C.E.M. de Die-Smulders ${ }^{\dagger}$ The authors consider that the first two authors should be regarded as joint first authors

Hum Reprod. 2018;33(11):2150-2157 


\section{Abstract}

\section{Study question}

Does preimplantation genetic diagnosis (PGD) increase the risk on adverse cognitive and socioemotional development?

\section{Summary answer}

The cognitive and socio-emotional development in children born after PGD seems to be norma when compared to control groups.

\section{What is known already}

A limited number of studies with small sample sizes indicate that the cognitive and socioemotional development of (pre)school-aged children born after either PGD or preimplantation genetic screening (PGS) seem to be comparable to those of children born after IVF/ICSI and naturally conceived (NC) children from the general population.

\section{Study design, size, duration}

For this study we invited 72 5-year-old PGD children, 128 5-year-old IVF/ICSI children and 108 5 year-old naturally conceived children from families with a genetic disorder. All children were invited between January 2014 and July 2016.

\section{Participants/materials, setting and methods}

51 PGD children, 52 IVF/ICSI children and 35 NC children underwent neuropsychological testing (WPPSI-III-NL and AWMA). The children's parent(s) and teachers filled in questionnaires evaluating children's executive functioning (BRIEF) and socio-emotional development (CBCL and C-TRF).

\section{Main results and the role of chance}

The mean full-scale IQ scores $(p=0.426)$ and performance on the AWMA Listening Span task $(p=0.873)$ and Spatial Span task $(p=0.458)$ were comparable between the three groups.

Regarding socio-emotional development, the teachers' scores revealed more externalising $(p=0.011)$ and total problem $(p=0.019)$ behaviour in PGD children than for IVF/ICSI children; both groups did not differ significantly from the NC children $(p=0.11)$. Though considered unlikely, we have to consider that the higher scores in PGD children may be the result of the inclusion of more children (13\%) with an affected first-degree family member (mostly parent) in the PGD group than in the NC group. However, it is important to keep in mind that scores in all groups still fell within the normal population range and should thus be considered normal.

\section{Limitations, reasons for caution}

The number of NC children from families with a genetic disorder was relatively small. Furthermore, the fathers' $\mathrm{CBCL}$ results were based on small samples.

\section{Wider implications of the findings}

PGD children show normal levels of cognitive and socio-emotional development at 5 years, despite the biopsy involved in PGD and the potential extra psychological burden associated with the presence of a genetic disorder in the family.

\section{Introduction}

Preimplantation genetic diagnosis (PGD) was first performed in 1990. It offers couples at risk of conceiving children with genetic disorders the opportunity to have an unaffected child of their own. ${ }^{1}$ In-vitro fertilisation (IVF)-treatment with or without intracytoplasmic sperm injection (ICSI) is required for PGD; this is followed by a biopsy of one or a few cells on day three, five or six after fertilisation. This biopsy is obligatory in order to select embryos that are not affected by the familial genetic disorder. ${ }^{2}$

The indication for PGD is different from the indication for other assisted reproductive technology (ART) treatment, the latter generally being offered as an infertility treatment. People opting for PGD either suffer from a specific genetic disorder themselves or are aware of a familial genetic disorder. It is conceivable that the presence of this type of disease in these families is associated with a higher level of psychological burden, which might pose a higher health risk for the whole family system, including the development of problem behaviour in their children. ${ }^{3}$ The presence of chronic illness in siblings or parents has been shown to increase the risk of behavioural problems in otherwise healthy children. ${ }^{4-6}$ There is thus a need to collect and compare data on cognitive and behavioural development of children born after PGD with data from children born after ART without PGD, and with data from naturally conceived children (NC) from families suffering from similar genetic diseases The need for a cell biopsy and the effect of this biopsy on the (mental) health and cognitive development of the children has also been a point of concern ever since PGD treatment was instigated. ${ }^{7-9}$ To date, studies focusing on children born after ART have mostly included children born after IVF and/or ICSI. In general, there is evidence that children born after ART, especially multiples, have an increased risk of adverse perinatal outcome, such as prematurity and low/very low birth weight..$^{10-15}$ Prematurity and lower birth weight are associated with lower cognitive functioning and an increased risk of impaired behavioural development at follow-up in schoolaged children, however, results from studies investigating cognitive outcomes in school-aged children conceived after ART are mostly reassuring. ${ }^{16-23}$

To date, only a few systematic studies have assessed the cognitive and socioemotional development of children born after PGD. Internationally, data from five PGD cohorts have been published. ${ }^{7,24-30}$

Although these studies provide reassuring results concerning the cognitive and socioemotional development of infants and (pre-)school-aged children born after PGD, there are large differences between the studies in age range (most included infants aged under three), in the number and type of control groups, and in the constitution 
of the PGD group. With regards to the latter, only Winter et al., Thomaidis et al. and Sacks et al. focused solely on PGD and compared them with either an ICSI and/or NC control group, though this latter control group consisted of families without a known genetic disorder, or they did not include a control group at all. ${ }^{27-30}$ The other studies included children born after PGD as well those born after preimplantation genetic screening (PGS) or PGS solely ${ }^{7,24-26,31,32}$ A cell biopsy is required for both PGD and PGS, however the indications differ; PGS is a form of aneuploidy screening used to optimize pregnancy rates after IVF treatment, whereas PGD is a diagnostic test for couples with an increased risk of offspring with a genetic disorder. It is important to independently study PGD and PGS because potential differences in outcome between children born after PGS may not be attributable to the embryo biopsy, but to factors related to infertility or maternal age. ${ }^{33,34}$ Therefore, more research is needed that compares the cognitive and socio-emotional development of children born after PGD. These should specifically focus on older children and later cognitive and socio-emotional development and should include multiple control groups accounting for potential effects of the biopsy while accounting for general effects of undergoing ART treatment and the potential extra psychological burden associated with the presence of a genetic disorder.

\section{The present study}

We compared children born after PGD with two control groups: IVF/ICSI children to measure the impact of the fertility/ART treatment in general, and with NC children from families with a genetic disorder to measure the effect of a familial genetic disorder and its potential emotional/psychological impact on parents/children. Whereas many previous studies have only assessed 2-3 year old children, we included 5-year-old children because cognitive functions such as $I Q$, working memory capacity and socioemotional functioning can, due to speed of development and brain maturation, reliably be assessed from this age. We note that pre-school scores on IQ and working memory capacity are highly predictive for future social and academic success. ${ }^{35-38}$

\section{Methods}

\section{Study population}

The PGD group ( $n=51$ ) was compared with an IVF/ICSI group ( $n=52)$ and a NC control group from families with a genetic disorder $(n=35)$. All children $(n=138)$ were Dutch speaking and born between May 2007 and April 2011. Prior to birth, parents of the PGD children had an initial consultation at Maastricht University Medical Center+'s (MUMC+) clinical genetics department, followed by IVF/ICSI treatment at either the MUMC+ or at one of the IVF transport-centers at the University Medical Center Utrecht (UMCU) or Groningen (UMCG). All biopsies were taken on day three, and all PGD analyses were performed at the MUMC+. The parents of the IVF/ICSI children underwent treatment at the MUMC+. The parents of the NC children either had an informative consultation regarding PGD but refrained from PGD treatment and became naturally pregnant, or had invasive prenatal testing (chorion villus biopsy or amniocentesis) at the MUMC+ because of a high risk of transmitting a genetic disorder to their offspring.

\section{Study procedure}

The children were included between January 2014 and July 2016 and were assessed at one of the participating hospitals, or in some cases, their parents' home.

The parent(s) first underwent a semi-structured interview. The date of birth, length, weight and the medical history of the parents, the child and potential siblings were recorded. Subsequently, the parents were asked to complete the Behaviour Rating Inventory of Executive Functions (BRIEF) and Child Behaviour Checklist (CBCL), as well as a questionnaire on their educational level, marital status and additional information on the medical history of their child. Each child's teacher was asked to fill in two questionnaires (BRIEF and Caregiver-Teacher Report Form (C-TRF)).

The children underwent an auxological, physical and neurological examination, of which the results will be reported elsewhere. Neuropsychological tests were administered by a qualified psychologist.

\section{Measurement instruments}

$1 Q$

The Wechsler Preschool and Primary Scale of Intelligence (WPPSI-III-NL) is a widely used, standardized test for assessing IQ in children aged 2.6-7.11 years. ${ }^{39,40} \mathrm{~A}$ full-scale IQ-score (FSIQ) was obtained, consisting of a verbal IQ-score (VIQ) and a performance IQ-score (PIQ).Standardized T-scores (population mean $(\mathrm{M})=100$ were entered in the analyses. 


\section{Working memory}

The currently used screener version of the Automated Working Memory Assessment Battery (AWMA) consists of a Listening Span task, measuring verbal working memory capacity, and a Spatial Span task, measuring visuo-spatial working memory capacity. ${ }^{41}$ The AWMA provides age adequate norm scores for the age range 4-22 years. Standardized $T$-scores (population mean $(M)=100$ were entered in the analyses.

\section{Executive functioning}

The Dutch version of the BRIEF, suitable for the 5-18 year age range was filled in by the children's parents and teachers. ${ }^{42}$ The resulting T-scores were entered in the analyses (population mean $(M)=50, S D=10$; a BRIEF Total T-score of $>65$ is considered to be in the problem range).

Socio-emotional development

To assess internalising behaviour (e.g. anxious, depressed) or externalising behaviour (e.g. hyperactive, aggressive) and total problem behaviour, we asked the parents and teachers to complete the Dutch version of the $\mathrm{CBCL}$ or the C-TRF. ${ }^{43}$ The resulting $T$-scores were entered in the analyses (population mean $(M)=50, S D=10$; a BRIEF Total $\mathrm{T}$-score of $>65$ is considered to be in the problem range).

\section{Ethics}

The study protocol was approved by the MUMC+ Medical Ethical Committee (NL43048.068.13 / METC 13-2-010). Informed written consent was obtained from all parents prior to the examination.

\section{Statistical analyses}

Data analyses were performed using the IBM Statistical Package for the Social Sciences (SPSS) version 23.0 (SPSS Inc, Chicago, IL). An alpha level of .05 (two-sided) was applied for all analyses.

To test for potential between-group differences in cognitive (IQ, working memory, executive functioning in daily life) and socio-emotional (CBCL/C-TRF) development between the groups, one-way analyses of variance (ANOVA) were performed on all dependent measures (eta-partial squared reported as effect size measure). Significant ANOVA omnibus tests were followed up by Bonferroni corrected post-hoc tests. First, a check for violations of the underlying assumptions for one-way ANOVA was carried out. Shapiro-Wilk's tests $(p<0.05)$ showed approximately normal distributions for Fullscale (FSIQ) and partial IQ (VIQ, PIQ) data from the WPPSI-III-NL and for the CBCL, CTRF-Total scale and BRIEF questionnaire data. Data from the C-TRF-Internalising scale, C-TRF-Externalising scale and AWMA Listening and Spatial span test showed stronger deviations from normality. Therefore, for these dependent measures, ANOVA tests were also performed on (log)transformed data, but since the ANOVA results for the non-transformed and transformed data did not differ, we report on the nontransformed data. Outlier analyses were performed by inspection of boxplots and reported in the results section. An outlier was defined as a score of either + 3SD or $-3 S D$ or more, from the mean group score. Levene's test showed equality of error variances between the groups for all dependent measures except for the WPPSI-VIQ subscale, the WPPSI-FSIQ scale and father's Internalising and Total CBCL scores.

\section{Results}

\section{Participant-specific and socio-demographic characteristics}

A total of 72 PGD children, 128 IVF/ICSI children and 108 NC children, were invited to participate. Fifty-one (including two twin pairs), 52 and 35 children respectively, and their parent(s) were included. Participation rates were $70.8 \%, 40.6 \%$ and $32.4 \%$, respectively. Table 5.1 summarizes the relevant child-specific and parental characteristics at baseline. A significant age difference at assessment time was noted for the three groups $\left(F(2,135)=5.289, p=0.006, \eta_{p}^{2}=0.073\right)$, but as only 5 -year-old children were invited for participation, the mean age differentiation in months was negligible. Furthermore, all dependent measures were age- (and mostly sex) standardized (T-) scores. Since no significant group differences were found for any of the other variables there was no need to include them as covariates in the ANOVA analyses.

\section{Characteristics PGD and NC group}

Six of the invited children in the NC group had a late-onset familial genetic disorder, but had an unknown genetic status. Only one of these children was included in the study. All other invited NC children were unaffected, as assessed by prenatal or postnatal testing. Further genetic characteristics of the PGD and the NC group are shown in Table 5.2. 


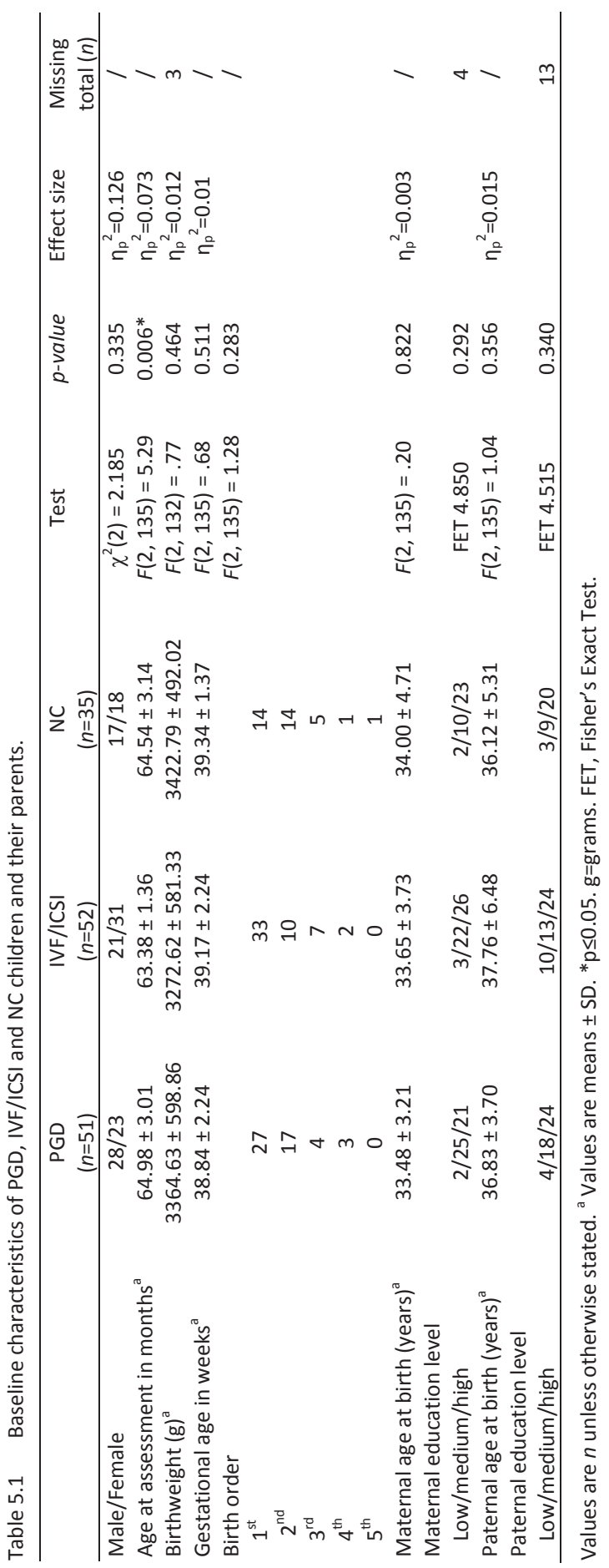

\begin{tabular}{|c|c|c|c|c|c|c|}
\hline & \multicolumn{2}{|c|}{ Invited } & \multicolumn{2}{|c|}{ Participated } & \multicolumn{2}{|c|}{$\begin{array}{l}\text { Participation \% of total pe } \\
\text { group }\end{array}$} \\
\hline & PGD & NC & PGD & NC & PGD & NC \\
\hline $\begin{array}{l}\text { No affected } 1^{\text {st }} \text { degree family member* } \\
\text { Affected } 1^{\text {st }} \text { degree family member }\end{array}$ & 24 & 24 & $19(79 \%)$ & $14(60 \%)$ & $37 \%$ & $40 \%$ \\
\hline Parent & $20^{\ddagger}$ & $29 \S$ & 13( & 2( & $25 \%$ & $6 \%$ \\
\hline Living si & 11 & 15 & $6(5$ & $4(2$ & $12 \%$ & $11 \%$ \\
\hline Decea. & 8 & 15 & $7(8$ & $7(4$ & $12 \%$ & $20 \%$ \\
\hline Parent carrier of $\mathrm{X}$-lin & 9 & 23 & $6(67 \%)$ & $8(35 \%)$ & $14 \%$ & $23 \%$ \\
\hline Invited child decease & 1 & 2 & 1 & 1 & / & 1 \\
\hline Total & 72 & 108 & $51(71 \%)$ & $35(32 \%)$ & $100 \%(n=51)$ & $100 \%(n=35)$ \\
\hline
\end{tabular}
Values are $n$ unless otherwise stated. Values in between brackets are percentage of responders to the autosomal recessive disorder t Nine parents were at risk for a late-onset disorder of whom four participated. $\$ 17$ parents were at risk for a late-onset disorder of whom 2 participated.

\section{Cognitive development}

\section{IQ (WPPSI-III-NL)}

Two cases were removed from the WPPSI-analysis, one in the PGD group due to a significant difference between VIQ and PIQ score, and one IVF/ICSI case who did not complete the tasks. Inspection of boxplots showed three outliers in the NC group for the verbal (VIQ) and full-scale (FSIQ) data) and one outlier in the IVF/ICSI group for the performance (PIQ) data. The one-way ANOVA analyses (including outliers) showed no statistically significant differences in FSIQ, VIQ and PIQ between the three groups (Table 5.3). All three groups scored above the population mean.

Removal of outliers did not change the ANOVA results and were thus retained, although the ANOVA omnibus test for VIQ became trend significant $(p=0.089)$, but Bonferroni corrected post-hoc tests revealed a non-significant trend only for higher $1 \mathrm{Q}$ in the IVF/ICSI than in the NC group $(p=0.08)$

\section{Working memory capacity (AWMA tests)}

One IVF/ICSI case was removed from the AWMA analyses because of incomplete data. There were no outliers in the Listening Recall data, but the Spatial Recall data showed six outliers; four in the PGD group and two in the IVF/ICSI group, all with higher score than the population mean ( $>$ than $98^{\text {th }}$ percentile) scores. Removal of these outliers did not affect ANOVA results and were retained. The one-way ANOVA analyses revealed no significant differences between the three groups on the Listening Span task and the Spatial Span task (Table 5.3). Moreover, scores were within the norma population range for all groups. 


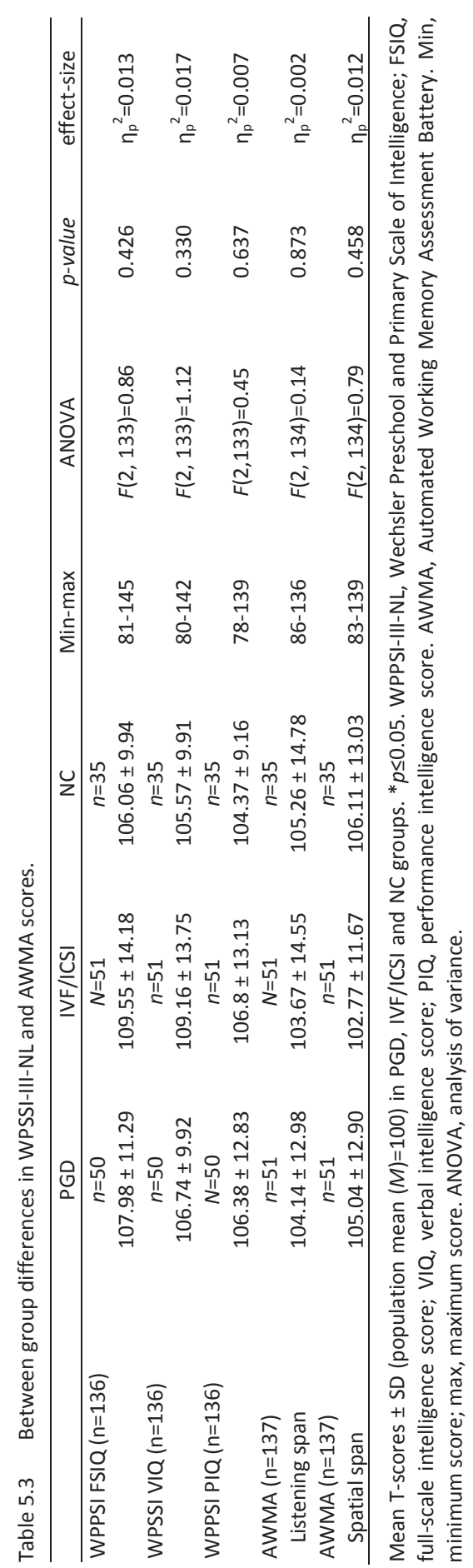

Executive functioning in daily life (BRIEF)

Two outliers were found in the IVF/ICSI group in the mothers' BRIEF data and four outliers in the NC group for the fathers' BRIEF data. The one-way ANOVA analyses including all children showed no significant differences between the PGD, IVF/ICSI, and NC groups in BRIEF-total T-scores obtained from fathers and teachers (Table 5.4). Exclusion of outliers in the father's data did not change these results. For mothers, the ANOVA omnibus test showed a non-significant trend $(p=0.07)$ that became significant $(p=0.035)$ after removal of the two outliers. Bonferroni corrected post-hoc tests, however, only showed trend-significant differences between the PGD and the other groups ( $p=0.08$ for both contrasts), with higher scores in the PGD group (Table 5.4). Moreover, the mean BRIEF Total T-scores from mothers, fathers and teachers were well below the population mean of $M=50$ (lower scores indicating better executive functioning).

\section{Socio-emotional development}

CBCL (Parents)

Inspection of the mothers' boxplots revealed: one outlier (in IVF/ICSI group with score 73) on the Externalising scale. Outliers in the fathers' data were: seven (all in the PGD group) on the Internalising scale, three (two in the PGD and one in the IVF/ICSI group) on the Externalising scale and one (in the PGD group) on the Total problem scale. The one-way ANOVA analyses including all children revealed no significant group differences between PGD, IVF/ICSI and NC groups in internalising, externalising and total problem behaviour, as reported by mothers and fathers (Table 5.4). Exclusion of outliers did not influence the fathers' results, and only influenced the result for the Externalising problem scale as rated by mothers, now becoming significant (was borderline significant): $F(2,129)=3,70, p<0.05, \eta_{p}{ }^{2}=0.054$. However, Bonferroni corrected post-hoc tests revealedtrend-significant differences between PGD and IVF/ICSI ( $p=0.055)$ and NC ( $p=0.081)$ groups, with higher scores in the PGD than in the other groups (Table 5.4). Mean T-scores in all groups were around or even below the normal population mean, lower scores indicating less problem behaviour. 


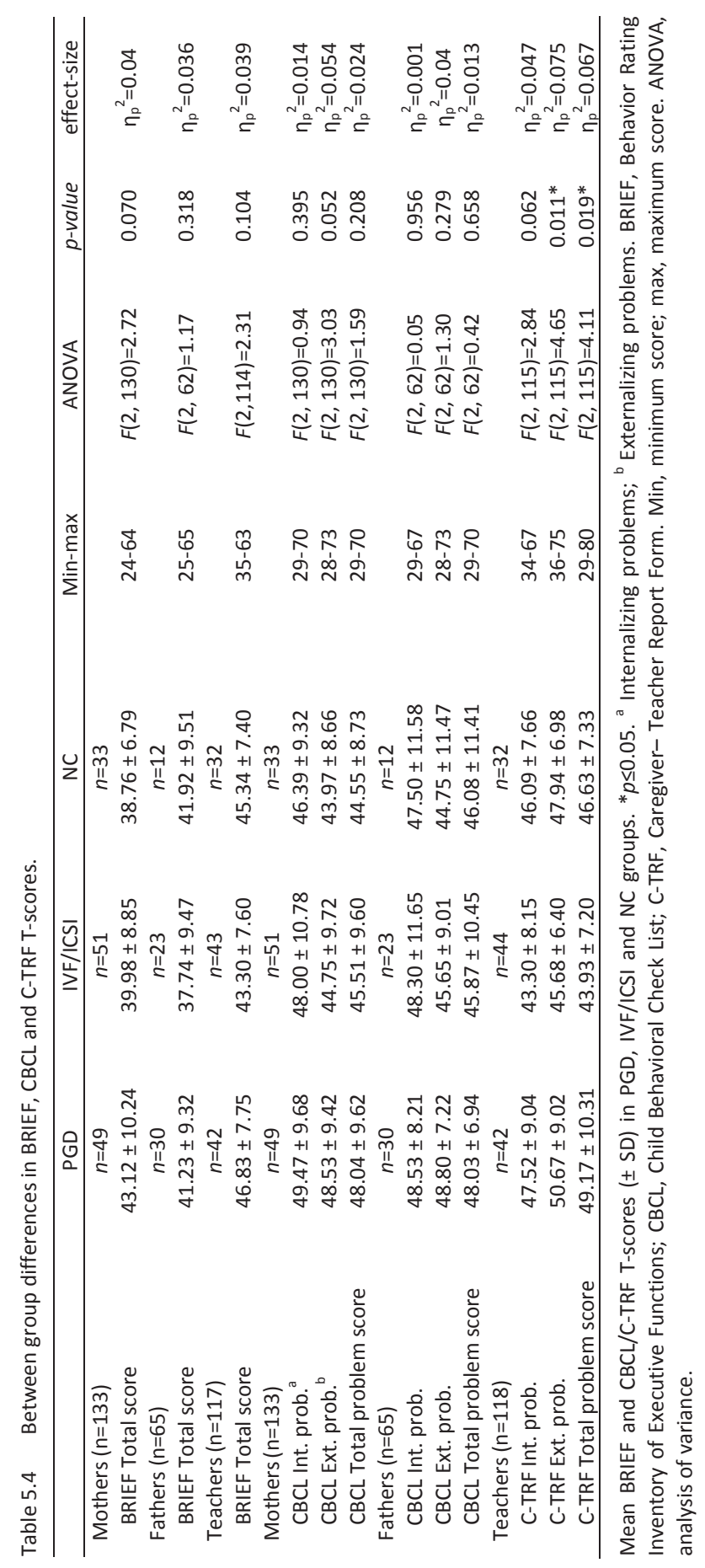

\section{C-TRF (teachers)}

Two outliers were found in the C-TRF-Externalising data (one in the PGD and one in the IVF/ICSI group), one outlier in the C-TRF-Total data (PGD group, same outlier as in Externalising data), and one outlier in the C-TRF-Internalising data (NC group), all with relatively high scores. Removal of these outliers did not change the reported ANOVA omnibus test and post-hoc test results, so the outliers were retained. The one-way ANOVA analyses yielded significant Group effects for externalising behaviour and total problem behaviour and a non-significant trend for internalising behaviour (Table 5.4). Bonferroni corrected post-hoc tests showed that C-TRF-Externalissing and Total scores were higher in the PGD than in the IVF/ICSI group (difTRF_EXT=4,98 $(\mathrm{SE}=1,6), p=0.003$, $\mathrm{LCl} 1,75 \mathrm{HCl}=8,22$ and dif C TRFTotal=-5,23 (SE=1,8), $p=0.015)$, LCl=-9,67, $\mathrm{HCl}=-0,80$ ), however both groups did not differ significantly from the NC group. Mean T-scores of all groups were around or below the normal population mean of $M=50$ (lower scores indicating less problem behaviour)

\section{Discussion}

In this study, we evaluate the cognitive and socio-emotional development of 5-yearold children born after PGD in the Netherlands. Overall, our findings are reassuring and comparable to those reported for PGD cohorts from other countries. ${ }^{7,24-30}$

We found no evidence for an adverse effect of PGD on the cognitive development of the children. No significant differences in verbal, performance or full-scale IQ-scores between the three groups were found and all three groups had mean IQ-scores above the population average. A possible explanation for the latter is the relatively high educational level of the parents. Earlier studies have reported that ART couples are often more highly educated compared to the general population. ${ }^{44,45}$ Their results were supported by Winter et al., who also found no differences in IQ-scores between children born after PGD or ICSI, and NC children. ${ }^{29}$ Compared to previous work, our study incorporated two extra working memory tests, however we found no differences in verbal and visuo-spatial working memory capacity between the three groups. This is a promising result considering the predictive value of children's working memory capacity for future cognitive and socio-emotional development and academic success. ${ }^{35-38,46-48}$ 
Executive functioning in daily life, as reported by the parents and teachers, was comparable in all three groups. All mean group scores were around or even below the population mean; lower scores indicate better executive functioning. Our results are thus in line with the findings by Sacks et al. ${ }^{27}$

The socio-emotional development scores did show some differences between PGD children and the control groups. Whereas fathers' $\mathrm{CBCL}$ scores did not reveal group differences, the mothers' $C B C L$ scores showed trend-significant $(p<0.1)$ higher scores on externalising problem behaviour in the PGD group compared to the IVF/ICSI and NC group. Furthermore, the PGD children's teachers reported significantly higher scores on Externalising and Total problem behaviour scales compared to those of IVF/ICSI children, but reported similar scores for the NC children. It is important to realize that analyses were performed on standardized scores, and mean problem behaviour scores on all scales fell well within (even below) that of the normal population range and were thus not indicative of any problem behaviour in all three groups.

Normal socio-emotional development, though without group differences, has also been reported by other researchers. ${ }^{25,27,30,31}$ It seems unlikely that the presence of a familial genetic disorder in PGD families could account for teacher's higher Externalizing behavior scores, since no difference was seen in teachers' ratings between the NC (also marked by the presence of genetic disorders) and IVF/ICSI groups. It is worth noting that the participation rate was higher in the PGD group compared to the NC group and, whereas NC and PGD groups had largely similar genetic disease family backgrounds, the PGD group included $13 \%$ more children with a first degree family member (mostly parent) affected with a genetic disorder. Although we consider it unlikely, we cannot exclude that this might have influenced the somewhat higher rating of Externalising behaviour scores on the CBCL in the PGD group as evaluated by the teachers. We postulate that, the Externalising behaviour scores in NC children may have been even higher if more children with an affected first degree family member had been included, indicating a possible effect of a familial genetic disorder on the children's socio-emotional development. Based on our results, it is unlikely that the embryo biopsy had an effect on the somewhat higher Externalising behaviour scores since no difference was seen between the PGD and NC groups. Replication of the present results in PGD and NC groups of children with even more closely matched genetic disease family backgrounds is thus highly desirable.

\section{Strengths and limitations}

The strength of our study is the inclusion of exclusively PGD (and not PGS) children and the comparison with a group of NC children with a familial genetic disorder. This approach enabled us to focus on potential consequences of the PGD treatment (the biopsy) on children's cognitive and socio-emotional development and on the possible effect of the presence of a genetic disease in the family. Moreover, by administering tests on executive functioning and working memory, especially at the age of five, we were able to give a more comprehensive evaluation of the possible effect of PGD on a child's cognitive development. Furthermore, adding a non-subjective rater (teacher) provided us with multi-informant data, giving even more insights in a child's socioemotional and behavioural development.

The higher response rate of the PGD group and the higher presence of affected first degree family members in this group is possible a limitation. The difference in response rate can, in our view, be best explained by the higher affinity of parents in the PGD group to the research question due to the fact that they had a child born after PGD. The slightly different genetic background of the PGD and NC children could have influenced the socio-emotional development scores, resulting in higher Externalising behaviour scores in PGD children and lower Externalising behaviour scores in NC children. Another possible limitation regarding the evaluation of children's socio-emotional development is that we included far fewer fathers than mothers. This led to uneven and small groups and made analysis of the father's data less reliable.

We conclude that the results of this study are reassuring since our sample of 5-yearold children born after PGD showed cognitive and socio-emotional development within the normal population range on all normed measurement instruments. The higher scores on Externalising and Total problem behaviour scales on the C-TRF in the PGD group, as reported by their teachers, were the most striking finding. It would be worthwhile exploring these problem behaviour scales in older PGD children. 


\section{References}

1. Handyside AH, Kontogianni EH, Hardy K, Winston RM. Pregnancies from biopsied human preimplantation embryos sexed by $Y$-specific DNA amplification. Nature. 1990;344(6268):768-770.

2. Handyside AH. Preimplantation genetic diagnosis after 20 years. Reprod Biomed Online. 2010;21(3):280-282.

3. Waldboth V, Patch C, Mahrer-Imhof R, Metcalfe A. Living a normal life in an extraordinary way: A systematic review investigating experiences of families of young people's transition into adulthood when affected by a genetic and chronic childhood condition. Int I Nurs Stud. 2016;62:44-59.

4. Romer, G., Barkmann, C., Schulte-Markwort, M., Thomalla, G., \& Riedesser, P. (2002). Children of Somatically III Parents: A Methodological Review. Clinical Child Psychology and Psychiatry. 2002;7(1): $17-38$.

5. Sieh DS, Visser-Meily JM, Oort FJ, Meijer AM. Risk factors for problem behavior in adolescents of parents with a chronic medical condition. Eur Child Adolesc Psychiatry. 2012;21(8):459-471.

6. Stoeckel M, Weissbrod C. Growing up with an ill parent: An examination of family characteristics and parental illness features. Fam Syst Health. 2015;33(4):356-362.

7. Banerjee I, Shevlin M, Taranissi M, et al. Health of children conceived after preimplantation genetic diagnosis: a preliminary outcome study. Reprod Biomed Online. 2008;16(3):376-381.

8. Desmyttere S, Bonduelle M, Nekkebroeck J, Roelants M, Liebaers I, De Schepper J. Growth and health outcome of 1022 -year-old children conceived after preimplantation genetic diagnosis or screening. Early Hum Dev. 2009;85(12):755-759.

9. Liebaers I, Desmyttere S, Verpoest W, et al. Report on a consecutive series of 581 children born after blastomere biopsy for preimplantation genetic diagnosis. Hum Reprod. 2010;25(1):275-282.

10. van Balen F. Development of IVF children. Dev Rev. 1998;18(1):30-46.

11. Basatemur E, Sutcliffe A. Follow-up of children born after ART. Placenta. 2008;29 Suppl B:135-140.

12. Eldar-Geva T, Srebnik N, Altarescu G, et al. Neonatal outcome after preimplantation genetic diagnosis. Fertil Steril. 2014;102(4):1016-1021.

13. Hansen M, Kurinczuk JJ, Milne E, de Klerk N, Bower C. Assisted reproductive technology and birth defects: a systematic review and meta-analysis. Hum Reprod Update. 2013;19(4):330-353.

14. Lu YH, Wang N, Jin F. Long-term follow-up of children conceived through assisted reproductive technology. J Zhejiang Univ Sci B. 2013;14(5):359-371.

15. Schieve LA, Meikle SF, Ferre C, Peterson HB, Jeng G, Wilcox LS. Low and very low birth weight in infants conceived with use of assisted reproductive technology N Engl J Med 2002:346(10):731-737.

16. Bhutta AT Cleves MA, Casey PH, Cradock MM, Anand KJ. Cognitive and behavioral outcomes of school-aged children who were born preterm: a meta-analysis. JAMA. 2002:288(6):728-737.

17. Shenkin SD, Starr JM, Deary IJ. Birth weight and cognitive ability in childhood: a systematic review. Psychol Bull. 2004;130(6):989-1013.

18. Sutcliffe AG, Ludwig M. Outcome of assisted reproduction. Lancet. 2007;370(9584):351-359.

19. Barbuscia A, Mills MC. Cognitive development in children up to age 11 years born after ART-a longitudinal cohort study. Hum Reprod. 2017;32(7):1482-1488.

20. Carson C, Kurinczuk $J$, Sacker A, et al. Cognitive development following ART: effect of choice of comparison group, confounding and mediating factors. Hum Reprod. 2010;25(1):244-252.

21. Middelburg KJ, Heineman MJ, Bos AF, Hadders-Algra M. Neuromotor, cognitive, language and behavioural outcome in children born following IVF or ICSI-a systematic review. Hum Reprod Update. 2008;14(3):219-231.

22. Rumbold AR, Moore VM, Whitrow MJ, et al. The impact of specific fertility treatments on cognitive development in childhood and adolescence: a systematic review. Hum Reprod. 2017;32(7): 1489-1507.

23. Wagenaar K, Ceelen M, van Weissenbruch MM, Knol DL, Delemarre-van de Waal HA, Huisman J. School functioning in 8- to 18-year-old children born after in vitro fertilization. Eur I Pediatr. 2008;167(11):1289-1295.
24. Nekkebroeck J, Bonduelle M, Desmyttere S, Van den Broeck W, Ponjaert-Kristoffersen I. Mental and psychomotor development of 2-year-old children born after preimplantation genetic diagnosis/screening. Hum Reprod. 2008;23(7):1560-1566.

25. Nekkebroeck J, Bonduelle M, Desmyttere S, Van den Broeck W, Ponjaert-Kristoffersen I. Socioemotional and language development of 2-year-old children born after PGD/PGS, and parental welbeing. Hum Reprod. 2008;23(8):1849-1857.

26. Nekkebroeck J, Van den Broeck W, Desmyttere S, Ponjaert-Kristoffersen I, Bonduelle M. The menta motor, socio-emotional and language development of 2-year-old twins born after PGD/PGS and parental well-being. Hum Reprod. 2012;27(1):299-301.

27. Sacks GC, Altarescu G, Guedalia J, et al. Developmental neuropsychological assessment of 4- to 5 year-old children born following Preimplantation Genetic Diagnosis (PGD): A pilot study. Child Neuropsychol. 2016;22(4):458-471.

28. Thomaidis L, Kitsiou-Tzeli S, Critselis E, et al. Psychomotor development of children born after preimplantation genetic diagnosis and parental stress evaluation. World I Pediatr. 2012:8(4): 309-316.

29. Winter C, Van Acker F, Bonduelle M, Desmyttere S, De Schrijver F, Nekkebroeck J. Cognitive and psychomotor development of 5- to 6 controlled matched study. Hum Reprod. 2014;29(9):1968-1977.

30. Winter C, Van Acker F, Bonduelle M, Desmyttere S, Nekkebroeck J. Psychosocial development of full term singletons, born after preimplantation genetic diagnosis (PGD) at preschool age and family casecontrolled study and multi-informant approach. Hum Reprod. 2015:30(5):1122-1136

31. Middelburg KJ, van der Heide M, Houtzager B, et al. Mental, psychomotor, neurologic, and behavioral outcomes of 2-year-old children born after preimplantation genetic screening: follow-up of a .

32. Schendelaar $\mathrm{P}$, Middelburg KJ, Bos AF, et al. The effect of preimplantation genetic screening on neurological, cognitive and behavioural development in 4-year-old children: follow-up of a RCT. Hum (2013;28(6):1508-1518.

33. Navot D, Bergh PA, Williams MA, et al. Poor oocyte quality rather than implantation failure as a cause of age-related decline in female fertility. Lancet. 1991;337(8754):1375-1377.

34. Sermon KD. Preimplantation genetic diagnosis. Verh K Acad Geneeskd Belg. 2006:68(1):5-32.

35. Alloway TP, Gathercole SE, Adams A, Willis C, Eagle JR, Lamont E. Working memory and phonological awareness as predictors of progress towards early learning goals at school entry. BR J Dev Psychol 2005; 3: 417-426.

36. Alloway TP, Alloway RG. Investigating the predictive roles of working memory and IQ in academic attainment. J Exp Child Psychol. 2010;106(1):20-29.

37. Baddeley AD, Hitch GJ. Working memory. In. Bower GA. (ed.). The psychology of learning and motivation. New York: Academic Press, 1974; 8: 47-90.

38. Gathercole $S E$, Brown L, Pickering SJ. Working memory assessments at school entry as longitudina predictors of national curriculum attainment levels. Educ Child Psychol 2003; 20: 109-122.

39. Wechsler D. Wechsler Preschool and Primary Scale of Intelligence III. Amsterdam: NCS Pearson, 2009.

40. Hendriksen J, Hurks P. WPPSI-III-NL. Wechsler Preschool and Primary Scale of Intelligence - Third Edition. Nederlandstalige bewerking. Afname- en scoringshandleiding. Amsterdam: Pearson, 2010.

41. Alloway TP. Automated Working Memory Assessment Manual. London: Pearson Education, 2007.

42. Huizinga M, Smidts D. BRIEF Vragenlijst executieve functies voor 5- tot 18-jarigen. Amsterdam: Hogrefe Uitgevers B.V., 2012.

3. Achenbach TM, Rescorla LA. Manual for ASEBA preschool forms \& profiles. Burlington, University of Vermont, Department of Psychiatry, USA, 2000.

44. Leunens L, Celestin-Westreich S, Bonduelle M, Liebaers I, Ponjaert-Kristoffersen I. Cognitive and motor development of 8-year-old children born after ICSI compared to spontaneously conceived children. Hum Reprod. 2006;21(11):2922-2929. 
45. Place I, Englert Y. A prospective longitudinal study of the physical, psychomotor, and intellectual development of singleton children up to 5 years who were conceived by intracytoplasmic sperm injection compared with children conceived spontaneously and by in vitro fertilization. Fertil Steril. 2003;80(6):1388-1397.

46. Diamond A, Lee K. Interventions shown to aid executive function development in children 4 to 12 years old. Science. 2011;333(6045):959-964.

Dunn JR. Health behavior vs the stress of low socioeconomic status and health outcomes. JAMA. 2010;303(12):1199-1200.

48. Kusche CA, Cook ET, Greenberg MT. Neuropsychological and cognitive functioning in children with anxiety, externalizing, and comorbid psychopathology. J. Clin. Child Psychol. 1993; 22: 172-195.

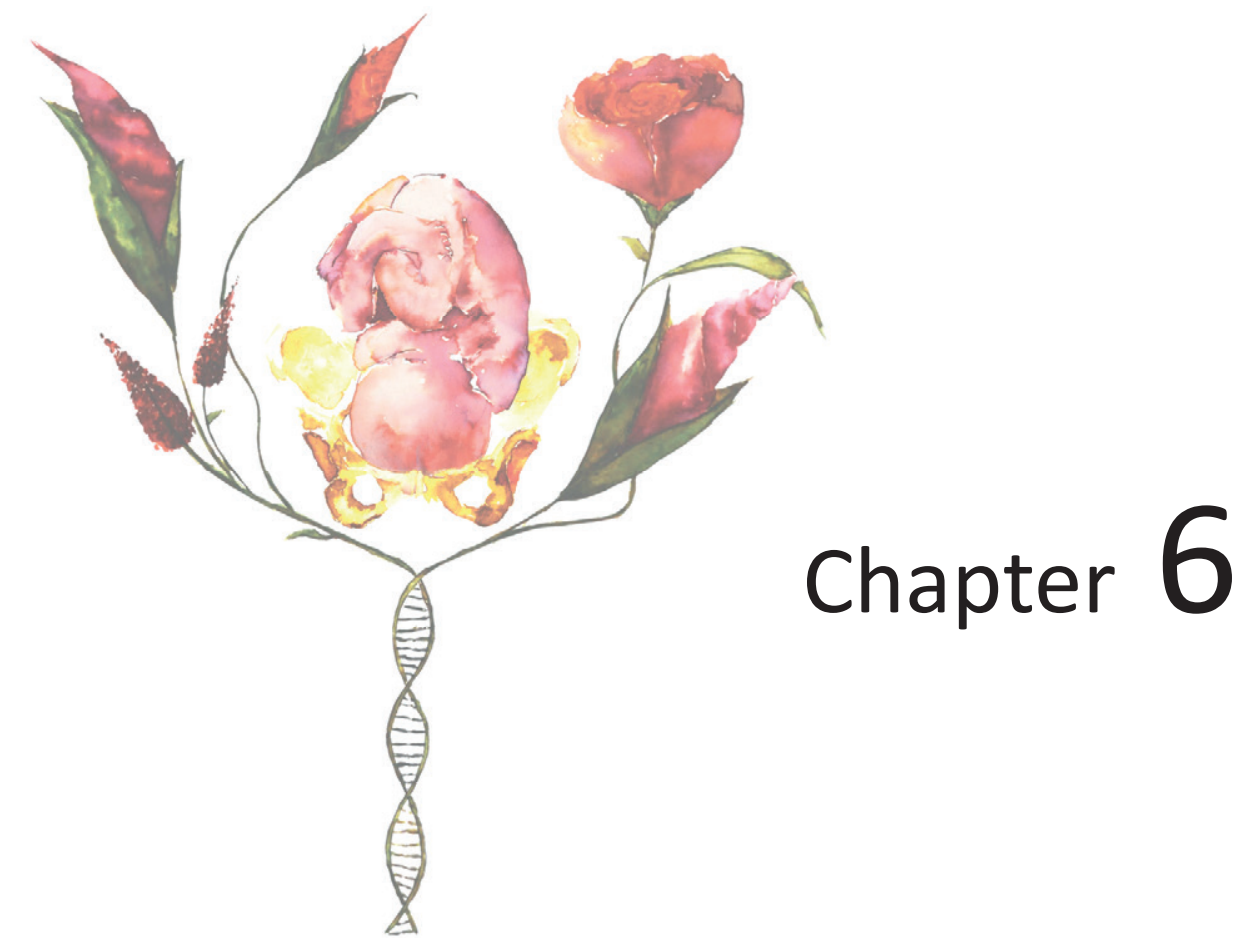

General discussion 


\section{General discussion}

\section{Background and aim of this thesis}

Nowadays, preimplantation genetic diagnosis (PGD) is part of regular health care for most couples with a high risk of transmitting a genetic disorder to their offspring. Executing IVF with embryonic cell biopsy, which is part of the PGD treatment, was considered experimental in the early years of PGD ${ }^{1,2}$ The number of applications for PGD has however increased enormously over the last three decades, ending up in about 500 referrals per year in the Netherlands in $2019 .^{3}$ Following the increasing number of referrals, also increasingly more children have been born after PGD. In the Netherlands, the Maastricht University Medical Center+ is the only licensed center to perform PGD under the condition of periodic evaluation and transparency. ${ }^{4}$

In most countries, pregnancies resulting from assisted reproductive technologies (ART; including PGD) are comprehensively monitored by means of extra ultrasounds or invasive prenatal testing because of a possible increased risk of congenital abnormalities and adverse perinatal outcome. ${ }^{5}$ The Dutch guideline for prenatal diagnostics has been revised in 2019. Since then no additional monitoring has been advised for pregnancies after ART. ${ }^{6}$ Prenatal screening for congenital abnormalities as part of regular Dutch antenatal care consists of NIPT for aneuploidy screening and an ultrasound examination at 18-20 weeks gestational age. Postnatal surveillance is part of a national screening program executed by youth health care physicians. Participation in these screening programs is however voluntarily. It can be considered striking that children who are born after PGD are monitored as every other child and on voluntary basis, in pregnancy as well as after birth. Especially, when considering the differences with international guidelines for pre- and postnatal care for ART pregnancies. ${ }^{5,6}$ By performing PGD we interfere in the early developmental period of life due to the necessity of an embryo biopsy and an IVF procedure with or without cryopreservation. Is it possible that such a complex procedure has no (adverse) effect on the pregnancy and the growth and development of the children born after PGD? Up until this thesis, the results of 25 years of PGD in the Netherlands had not been extensively evaluated yet. This thesis is therefore an evaluation of our performances and about safety of PGD.

Not only the knowledge about the health of children born following PGD in the Netherlands is scarce, also international data are limited. Following the ESHRE PGD consortium guidelines, all parents of children born after PGD in the Netherlands 
receive a follow-up questionnaire after the birth of their child including questions about the obtained prenatal care and ultrasounds results, details regarding the delivery and birth parameters of the child(ren). ${ }^{7}$ All parents are asked for consent for the request of additional medical data. The collected data are published annually in a national open access year report and are also included in the international PGD follow-up database of the ESHRE (European Society for Human Reproduction and Embryology) PGD consortium. ${ }^{3,8}$ Up until now, actual evaluation of the Dutch data was lacking which is part of this thesis (Chapter $\mathbf{2}$ and $\mathbf{3}$ ).

In order to interpret the Dutch data, we have reviewed the existing literature regarding the follow-up of PGD pregnancies and children and tried to uncover the knowledge gaps, striking findings and discrepancies. Most published follow-up data where gathered by a Belgian study group, who compared their PGD data to data from pregnancies and children following IVF/ICSI treatment. ${ }^{9-11}$ Other, mostly smaller, cohorts were published by study groups from the UK, the USA, Israel and Denmark. ${ }^{12-}$

${ }^{15}$ We found that both, the number of included pregnancies and children per study, and the total number of executed studies were low. Thereby, most of the published studies did not only include pregnancies after PGD but also pregnancies following preimplantation genetic screening (PGS). PGS is offered as part of a fertility treatment in order to increase pregnancy rates by executing chromosomal screening before the embryo(s) is/are transferred into the uterus. ${ }^{16}$ Couples opting for PGD thus differ from couples opting for PGS, since the latter are treated because of a fertility problem and have no increased risk of transmitting a genetic disorder to their offspring. The presence of a genetic disorder in a family and increased risk of transmitting such disorder to the offspring may also cause psychological burden related to the existence of an affected future parent or an affected earlier child. ${ }^{17}$ Data from PGD and PGS cohorts should therefore ideally be analysed separately. PGS is, up until now, not part of the Dutch regular IVF (with or without PGD) practice. This gave us the opportunity to collect data of solely PGD cohorts. Another notable finding in literature was that most PGD cohorts were compared to IVF with or without ICSI cohorts. Comparing PGD with IVF/ICSI is obvious, if the research question is what the additional risk of the PGD procedure is on top of the IVF procedure. It should nevertheless be kept in mind that an effect of subfertility or the underlying genetic disorder cannot be ruled out in this comparison. Furthermore, in clinical practice, IVF is not an alternative option to avoid the transmission of a genetic disorder. It is therefore that we choose to add a third control group of naturally conceived children from families with a genetic disorder (NC group) for our follow up studies of children (chapter 4 and 5). Additionally, we compared our data to population data. Comparing PGD children with the NC group and with population data is closer to daily practice in which the couples can choose for a natural conception with or without invasive prenatal testing as an alternative for PGD. Whereas IVF/ICSI is not an alternative since subfertility is not the reason to perform PGD.

\section{Increasing number of genetic indications and recent innovations}

This thesis includes solely pregnancies and children born following PGD after blastomere biopsy at day three with either FISH, array-CGH or PCR. All included PGD treatments were performed before 2014, since the studied children had to be aged five years old in order to meet the inclusion criteria of our follow-up study. PGD practice is, however, changing and innovating over the years with the introduction of, for instance, new biopsy techniques and new diagnostic approaches.

The number of couples that apply for PGD is increasing over the years. This may be partly due to the growing knowledge of both genetic counsellors and candidate couples of PGD. The expanded use of internet, for instance, makes is easier for the counsellors and the couples to search for information about PGD. Thereby, the internet facilitates the possibility to reach a broad audience for publicity about PGD. Information about PGD is not only more accessible, the number and diversity of disorders for which PGD has been done has also increased. ${ }^{3}$ The diagnostic field in genetics has developed tremendously over the last years, resulting in the discovery of the genetic cause for an increasing number of severe genetic disorders. Especially the implementation of whole exome sequencing (WES) makes it possible to examine several genes at once and increases the diagnostic success rate, resulting in the discovery of rare genetic disorders and a growing number of patients with a genetic diagnosis. The recent introduction of preconception carrier screening (PCS) will identify couples who are at risk for transmitting one or more (severe) genetic disorder(s) to their offspring already before an established pregnancy. ${ }^{18,19}$

Until recently, most PGD treatments have been performed by use of blastomere biopsy at the cleavage stage in combination with either FISH, array-CGH, or PCR. The use of such diagnostic approach desires a detailed and, in case of FISH or PCR, a personalized protocol. The development of such a personalized protocol is complex, time consuming, and requests the involvement of the couples family members. ${ }^{2,7,20-22}$ Recently, a new biopsy method, called trophectoderm biopsy (TE biopsy), was 
introduced in PGD practice. TE biopsy is performed at the blastocyst stage at day five or six after fertilization. ${ }^{23,24}$ In contrast to blastomere biopsy, TE biopsy makes it possible to aspirate more cells (five to ten cells) and thus more DNA is available for the genetic analysis. Moreover, the TE biopsy is taken from the trophectoderm not touching the inner cell mass (ICM) which becomes the embryo proper. The timing of TE biopsy makes cryopreservation of the embryos necessary as modern diagnostic procedures cannot be performed and completed in two days, the window of fresh embryo transfer. Thawing of the embryo and transfer into the uterus usually takes place several weeks after the IVF procedure, resulting in enough time for the complex genetic analysis. ${ }^{23,24}$

Comprehensive chromosome analysis by use of Next Generation Sequencing (NGS) is a novel way of determining whether an embryo is euploid or aneuploid. Small embryonic DNA fragments are sequenced and compared to a reference genome as well as counted. This technique makes is possible to detect both whole chromosomal aberrations and segmental chromosomal imbalances. Chromosomal analysis by use of NGS has lower costs, has enhanced precision and makes it possible to test multiple embryos at once. ${ }^{25,26}$

An efficient alternative to single-cell PCR for monogenic disorders is the whole genome amplification and SNP haplotyping approach. This technique makes it possible to identify high-risk haplotypes based on the detection of multiple single nucleotide polymorphic markers linked to the gene of interest. The designed protocols are generic and thus applicable for several families with the same familial single-gene disorder but different pathogenic mutations. ${ }^{27,28}$

The most recent innovation is the concept of preimplantation genome-wide single-cell haplotyping with the use of NGS. PGD with NGS facilitates a comprehensive genetic analysis for familial monogenic disorders as well as chromosomal anomalies and makes it possible to use a 'one-fits-all' protocol instead of a personalized protocol, which is therefore termed OnePGT (Preimplantation Genetic Testing). ${ }^{23,24}$ OnePGT leads to a less complex and less time consuming preparation time which seems a perfect answer to the growing demand for PGD. Moreover, OnePGT makes it possible to perform genetic analysis for more than one indication after just one single biopsy and to perform additional aneuploidy screening. ${ }^{29,30}$
Our study results in relation to recent innovations

Our studies on pregnancies following PGD (chapter 2) and the accompanying perinatal data (chapter 3) show promising results. The risk for fetal loss was not increased. The risk for obstetric complications was comparable to the risk in the control group and the children born after PGD had no increased risk for adverse perinatal outcome. At the age of five they had a normal physical health and cognitive and socio-emotional development (chapter $\mathbf{4}$ and $\mathbf{5}$ ). Implementation of our conclusions in daily practice may however be done with certain caution since our results are retrieved from data regarding pregnancies after biopsy at cleavage stage, and are thus not per definition also applicable for pregnancies after TE biopsy.

\section{PGD pregnancies and perinatal data}

The use of TE biopsy changes the PGD procedure significantly since the biopsy takes place at a later stage in embryonic development (day 5/6 vs. day 3). An extended culture time, as required for TE biopsy, may be associated with higher clinical pregnancy rates but also with an increased risk of some adverse perinatal outcome, particularly preterm birth. ${ }^{31,32}$ Other studies report that TE biopsy may probably increase the risk of preeclampsia and thus the risk of a more complex pregnancy course and adverse prenatal outcome. ${ }^{33}$ Reasoning further, TE biopsy might increase the risk for stillbirths and perinatal mortality as more pregnancies are complicated due to preeclampsia and adverse perinatal outcome. Earlier studies on PGD also report concerns regarding fetal mortality after PGD, whereas we report a lower incidence of stillbirths in our group of PGD singletons (chapter 3). ${ }^{11,34}$ Most of our data were distracted from pregnancies following fresh embryo transfer, whereas TE biopsy must be followed by cryopreservation in order to gather enough time for genetic testing. Cryopreservation would decline the risk for adverse perinatal outcome like stillbirths and low birth weight, but could induce other adverse outcomes like large for gestational age. Studies on adverse obstetric outcome after cryopreservation show conflicting results, reporting both an increased and decreased risk for obstetric complications. ${ }^{35,36}$ Techniques for cryopreservation change over time and the use of cryopreservation makes it possible to transfer embryos in a more natural cycle. Overall, we feel that the use of techniques like TE biopsy and cryopreservation are significantly different from the techniques mostly used in the PGD treatments that we 
included in this thesis. Implementation of our results in current PGD practice should thus be done with certain caution.

Remarkably, we reported a higher incidence of monozygotic twins in our PGD group than in our IVF group (chapter 2). Monozygotic twin pregnancies have higher complexity and higher risk for adverse perinatal outcome. ${ }^{37}$ ART is known to increase the risk for monozygotic twinning, but the embryo biopsy in PGD may play an additional role in the development of such twin pregnancies due to zona pellucida manipulation which may lead to disruption and splitting of the ICM. ${ }^{76-39} \mathrm{TE}$ biopsy is performed at a later embryonic stage and therefore might increase the risk for monozygotic twinning with a monochorionic and diamniotic pattern or even a monochorionic and monoamniotic pattern. The latter, even has the highest potential to lead to conjoined twinning. ${ }^{40}$

Not only continuation of the evaluation for possible obstetric risks, like preeclampsia and monozygotic twinning, in PGD pregnancies is advised, also evaluation of the risk for misdiagnosis is desirable. We reported only a few misdiagnoses during almost twenty-five years of PGD. The first misdiagnosis concerned a complex PGD protocol using the FISH technique for a chromosomal translocation including the $X$ chromosome (chapter 3). ${ }^{41}$ The corresponding pregnancy resulted in an early miscarriage due to a chromosomal imbalance. In more recent years there was another misdiagnosis for a chromosomal anomaly, using the FISH technique. The third misdiagnosis concerned a twin pregnancy after the transfer of a single embryo following PCR for an autosomal recessive disorder in a consanguineous couple. ${ }^{42}$ Misdiagnosis can occur due to a human error, an intrinsic (embryonic) error or an extrinsic (technical) error or can result from an intervening spontaneous pregnancy. Examples of these errors are, for instance, misidentification or mislabelling, embryonic mosaicism, parental contamination or recombination. High quality standards in the PGD laboratories may lower the risk of misdiagnosis but single cell diagnosis remains technically challenging. ${ }^{20,43}$ Because of the risk for misdiagnosis invasive prenatal diagnosis (chorionic villus sampling or amniocentesis) is offered in all pregnancies following PGD. The necessary procedures, are however invasive, and therefore increase the risk for miscarriages. This may be one of the reasons why most couples do not choose to confirm the PGD diagnosis with invasive prenatal procedures. ${ }^{34}$ The future implementation of non-invasive prenatal testing and diagnosis (NIPT/NIPD), which is performed on cell-free fetal DNA derived from maternal blood, will give couples the opportunity to test for misdiagnosis without the increased risk for miscarriages. ${ }^{44}$ New techniques like TE biopsy may, on the other hand, decrease the risk for misdiagnosis since more cells are available for genetic analysis. ${ }^{45}$ The implementation of NGS in the current PGD practice is another important innovation and a significant improvement of the PGD procedure. Recently, a multi-center evaluation study on the concordance between previous PGD analysis and PGD analysis with the use of NGS showed a concordance of $100 \%{ }^{30}$ Further evaluation of the safety of NGS for the offspring was not part of the latter study, so far, but could add extra knowledge about the misdiagnosis risk.

The implementation of NGS makes it possible to analyse more than the condition PGD was requested for. Probably NGS might make it possible in the near future to screen embryos for more than one condition in vitro, and thus perform 'prenatal and/or newborn screening' just after conception instead of during pregnancy and after birth Currently, all pregnant women are offered non-invasive prenatal testing for trisomy 13,18 and 21. And all babies are offered newborn screening in the first days of their life. Whether it is desirable to screen embryos for several genetic conditions is both a medical as well as an ethical question but for sure an important topic to discuss in the nearby future. The implementation of NGS will decrease the turnaround time and also lowers the test-specific costs of PGD. This can contribute to the debate about the strict indications for PGD. If the test is less time consuming and cheaper than earlier tests, why not broaden our indications and give more couples the option to opt for PGD. Also, this latter point, is matter of debate.

Another upcoming innovation, is non-invasive preimplantation genetic testing ( $\mathrm{NI}$ PGT). This technique will make it possible to test for genetic disorders without performing an embryo biopsy. The required embryonic DNA will be gathered from the blastocoel fluid or from spent culture media instead of from the embryo itself. Up until now, it is however not fully confirmed whether the DNA fragments in the blastocoel fluid or spent culture media are a reliable source of embryonic genomic information. $^{46,47}$ The concordance between these DNA fragments and the DNA derived directly from the embryo should be confirmed before implementation of $\mathrm{NI}$ PGT in clinical practice. NI-PGT could in the future not only be implemented as a diagnostic method for genetic disorders, but also as a screening method comparable to current aneuploidy screening in regular IVF/ICSI. ${ }^{48}$ Non-invasive aneuploidy testing and screening might, when successfully implemented, reduce the time to pregnancy and decrease the miscarriage rate which may be of great value for the couples opting for regular IVF/ICSI. 
Growth, physical health and cognitive and socio-emotional development of children born after PGD

We reported that the growth and health of five-year-old children born after PGD were normal (chapter 4). However, we did find a relatively high percentage of children with an acute illness in their medical history (82.5-90.0\%). We interpreted this finding as a result of precautionary measures in children who were specially conceived and thus not as a result of the PGD procedure itself. It may, though, be valuable to re-evaluate this finding in a larger group of children from different ages and to compare the findings to population data.

We also report on the cognitive and socio-emotional development of these children (chapter 5). We found that levels of cognitive and socio-emotional development at the age of five are within the normal range. Only the teachers' scores revealed more externalizing and total problem behavior in PGD children than in IVF children. This difference was not found when both groups of children were compared to the group of naturally conceived (NC) children. We could not exactly explain this finding but found that the children in the PGD group more often had an affected first degree family member than the children in the NC group. We hypothesized that this could explain the different teachers' scores. Since the mean scores were within the norm range, we concluded that we could not prove that either the biopsy nor the potentia extra psychological burden associated with the presence of a genetic disorder in the family are associated with adverse socio-emotional development.

Our current follow-up program mainly focuses on the health of the women and young children born after PGD, but the effect of PGD later in life (long-term safety) has not been studied yet. Studying long-term safety is important since there is some evidence for cardiometabolic differences between children born after ART compared to naturally conceived children. ${ }^{49-53}$ Similar to fetal epigenetic programming of metabolism and the consequences for adult health, early embryonic epigenetic mechanisms are thought to play an important role in ART-induced cardiovascular dysfunction with premature vascular ageing as a result. ${ }^{54}$ One of the clinical signs of vascular dysfunction in children born after ART is an increased arterial blood pressure. ${ }^{51}$ Other important cardiovascular alterations in children born after ART are insulin resistance, endothelial dysfunction, arterial stiffness and thickening of the intima media. ${ }^{53}$ The general concern is that these alterations ultimately lead to cardiovascular morbidity and mortality in later life. Specifically it would be interesting to study the additional effect of the embryo biopsy on epigenetic mechanisms and consequently on cardiovascular function. Recording the effects on epigenetic mechanisms, could facilitate the possibility to start future studies on how to influence these epigenetic mechanisms in order to improve the (long term) PGD results.

\section{Strengths and limitations}

The strength of this thesis is that all studies included solely children born after PGD, whereas other follow-up studies on the risks of PGD also include children born after preimplantation genetic screening (PGS). For both PGD and PGS an embryo biopsy is needed. The main difference between PGD and PGS is the indication for the treatment. The goal in PGD is to select embryos without a familial genetic disorder; the goal in PGS is to increase the pregnancy chance in IVF/ICSI by excluding aneuploid embryos. Parental characteristics, such as parental disease in the PGD group or male infertility or increased maternal age in the PGS group, could have influenced the results of studies on the safety of the procedure and stresses the value of evaluating both forms of ART (PGD and PGS) as two separate entities.

The evaluation of the offspring at different ages, starting in the fetal period and ending at the age of five, gives a good view on the short term safety of PGD. Especially the data on obstetric and perinatal outcome were extracted from a large cohort of pregnancies after PGD (chapter $\mathbf{2}$ and $\mathbf{3}$ ). Also the group of 5-year-old children was one of the largest PGD study groups reported so far (chapter 4 and 5). Still, the amount of children included is not sufficient for the detection of small differences between the groups. Therefore, the current follow-up program should be continued in order to enlarge the study groups.

A third strength of this thesis is the choice for a control group of naturally conceived children from families with a genetic disorder (NC group), in addition to a control group of children born after IVF/ICSI (chapter $\mathbf{4}$ and $\mathbf{5}$ ). The genetic status of the families in the NC group is comparable to the genetic status of families opting for PGD. The NC group mostly contained children form parents who intended to choose for PGD but eventually, for different reasons, conceived naturally and probably opted for prenatal testing. Thus the choice for two control groups, one consisting of children born after IVF/ICSI and one being the NC group, made it possible to evaluate the effect of the IVF/ICSI treatment as well as the effect of the genetic burden on top of the effect of the biopsy.

The choice for this particular NC group is also relevant in clinical practice, since an alternative for PGD is natural conception with or without invasive prenatal testing and 
thus often discussed in the PGD clinic. The results of chapters $\mathbf{4}$ and $\mathbf{5}$ can be helpful for both genetic counselors and the couples themselves when discussing the pros and cons of the couples reproductive options.

A limitation of the studies in this thesis is that the data are solely based on PGD with blastomere biopsy, whereas TE biopsy is increasingly replacing blastomere biopsy. The current results are thus applicable for the children who are already born but only partly for future purpose when most children are born after PGD with TE biopsy. Stil this thesis can function as a model for future studies on the safety of TE biopsy. The same applies for the implementation of new techniques for the genetic analysis, like NGS. For instance, the risk for misdiagnosis in PGD with use of PCR, FISH, or CNV-array has been extensively studied, but gives no insight in the risk for misdiagnosis after PGD with use of NGS based techniques. NGS will also make PGD for multiple genetic disorders more accessible. The effect of such options on the couple, the offspring and also on the safety of the PGD procedure cannot be predicted based on this thesis.

\section{Conclusion}

Overall, we feel that the results of the currently completed PGD procedures are reassuring. However, continuous follow-up is definitely desirable since innovative techniques have been implemented the last couple of years and should be evaluated as well. The current innovations in the world of PGD will not be the last innovations. The positive and adverse effects of each of these options as part of the PGD procedure should be evaluated. Furthermore, there is a need for long term follow-up studies in a larger group of children born after PGD, and comparison with valid control groups. Couples opting for PGD should be informed that PGD is a safe procedure with regard to the health and development of children born after PGD up to now. However, this information should be provided with some restraint, because of the lack of data on the effect of new techniques and the lack of information about older children born after PGD. Currently, there seems to be no need to advise additional antenatal or postnatal screening in PGD pregnancies and children.

\section{References}

1. Handyside AH, Kontogianni EH, Hardy K, Winston RM. Pregnancies from biopsied human preimplantation embryos sexed by Y-specific DNA amplification. Nature. 1990;344(6268):768-770.

2. Harper JC, Sengupta SB. Preimplantation genetic diagnosis: state of the art 2011. Hum Genet. 2012;131(2):175-186

3. PGD jaarverslag 2018. Available at https://www.pgdnederland.nl/jaarverslagen.

4. Aarden E, Van Hoyweghen I, Vos R, Horstman K. Providing preimplantation genetic diagnosis in the United Kingdom, The Netherlands and Germany: a comparative in-depth analysis of health-care access. Hum Reprod. 2009;24(7):1542-1547.

5. Velez MP, Hamel C, Hutton B, et al. Care plans for women pregnant using assisted reproductive technologies: a systematic review. Reprod Health. 2019;16(1):9. Published 2019 Jan 29.

6. Leidraad indicatiestelling prenatale diagnostiek. 2019. Available at https://www.nvog.n// kwaliteitsdocumenten/leidraden/

7. Harton G, Braude P, Lashwood A, et al. ESHRE PGD consortium best practice guidelines for organization of a PGD centre for PGD/preimplantation genetic screening [published correction appears in Hum Reprod. 2012 Aug;27(8):2569]. Hum Reprod. 2011;26(1):14-24.

8. De Rycke M, Goossens V, Kokkali G, Meijer-Hoogeveen M, Coonen E, Moutou C. ESHRE PGD Consortium data collection XIV-XV: cycles from January 2011 to December 2012 with pregnancy follow-up to October 2013. Hum Reprod. 2017;32(10):1974-1994.

9. Desmyttere S, Bonduelle M, Nekkebroeck J, Roelants M, Liebaers I, De Schepper J. Growth and health outcome of 102 2-year-old children conceived after preimplantation genetic diagnosis or screenine. Early Hum Dev. 2009;85(12):755-759.

10. Desmyttere S, De Rycke M, Staessen C, et al. Neonatal follow-up of 995 consecutively born children after embryo biopsy for PGD. Hum Reprod. 2012;27(1):288-293.

11. Liebaers I, Desmyttere $S$, Verpoest W, et al. Report on a consecutive series of 581 children born after blastomere biopsy for preimplantation genetic diagnosis. Hum Reprod. 2010;25(1):275-282.

12. Bay B, Ingerslev HJ, Lemmen JG, Degn B, Rasmussen IA, Kesmodel US. Preimplantation genetic diagnosis: a national multicenter obstetric and neonatal follow-up study. Fertil Steri. 2016;106(6):1363-1369.e1.

13. Hasson $\downarrow$, Limoni D, Malcov $M$, et al. Obstetric and neonatal outcomes of pregnancies conceived after preimplantation genetic diagnosis: cohort study and meta-analysis. Reprod Biomed Online. 2017;35(2):208-218.

14. Strom CM, Strom S, Levine E, Ginsberg N, Barton J, Verlinsky Y. Obstetric outcomes in 102 pregnancies after preimplantation genetic diagnosis. Am J Obstet Gynecol. 2000;182(6):1629-1632.

15. Sunkara SK, Antonisamy B, Selliah HY, Kamath MS. Pre-term birth and low birth weight following preimplantation genetic diagnosis: analysis of 88010 singleton live births following PGD and IVF cycles. Hum Reprod. 2017;32(2):432-438.

16. Natsuaki MN, Dimler LM. Pregnancy and child developmental outcomes after preimplantation genetic screening: a meta-analytic and systematic review. World J Pediatr. 2018;14(6):555-569.

17. Waldboth V, Patch C, Mahrer-Imhof R, Metcalfe A. Living a normal life in an extraordinary way: A systematic review investigating experiences of families of young people's transition into adulthood when affected by a genetic and chronic childhood condition. Int J Nurs Stud. 2016;62:44-59.

18. Borry P, Henneman L, Lakeman P, ten Kate LP, Cornel MC, Howard HC. Preconceptional genetic carrier testing and the commercial offer directly-to-consumers. Hum Reprod. 2011;26(5):972-977.

9. Abulí A, Boada M, Rodríguez-Santiago B, et al. NGS-Based Assay for the Identification of Individuals Carrying Recessive Genetic Mutations in Reproductive Medicine. Hum Mutat. 2016;37(6):516-523.

20. Dreesen J, Destouni A, Kourlaba G, et al. Evaluation of PCR-based preimplantation genetic diagnosis applied to monogenic diseases: a collaborative ESHRE PGD consortium study. Eur J Hum Genet. 2014;22(8):1012-1018

21. Harton GL, De Rycke M, Fiorentino F, et al. ESHRE PGD consortium best practice guidelines for amplification-based PGD. Hum Reprod. 2011;26(1):33-40. 
22. Harton GL, Harper JC, Coonen E, et al. ESHRE PGD consortium best practice guidelines for fluorescence in situ hybridization-based PGD. Hum Reprod. 2011;26(1):25-32.

23. Scott RT Jr, Upham KM, Forman EJ, Zhao T, Treff NR. Cleavage-stage biopsy significantly impairs human embryonic implantation potential while blastocyst biopsy does not: a randomized and paired clinical trial. Fertil Steril. 2013;100(3):624-630.

24. Lathi RB, Massie JA, Gilani M, et al. Outcomes of trophectoderm biopsy on cryopreserved blastocysts: a case series. Reprod Biomed Online. 2012;25(5):504-507.

25. Fiorentino F, Biricik A, Bono $S$, et al. Development and validation of a next-generation sequencingbased protocol for 24-chromosome aneuploidy screening of embryos. Fertil Steril. 2014;101(5): $1375-1382$.

26. Fiorentino F, Bono S, Biricik A, et al. Application of next-generation sequencing technology for comprehensive aneuploidy screening of blastocysts in clinical preimplantation genetic screening cycles. Hum Reprod. 2014;29(12):2802-2813.

27. Renwick PJ, Trussler J, Ostad-Saffari E, et al. Proof of principle and first cases using preimplantation enetic haplotyping paradigm shift for embryo diagnosis. Reprod Biomed Online. 2006:13(1): 110-119.

28. Natesan SA, Bladon AJ, Coskun S, et al. Genome-wide karyomapping accurately identifies the Com 2014;16(11):838-845.

29. Zamani Esteki M, Dimitriadou E, Mateiu L, et al. Concurrent whole-genome haplotyping and copynumber profiling of single cells. Am J Hum Genet. 2015;96(6):894-912.

30. Masset H, Zamani Esteki M, Dimitriadou E, et al. Multi-centre evaluation of a comprehensive Estic test through haplotyping-by-sequencing. Hum Reprod 2019:34(8) 608-1619.

31. Glujovsky D, Farquhar C, Quinteiro Retamar AM, Alvarez Sedo CR, Blake D. Cleavage stage versus blastocyst stage embryo transfer in assisted reproductive technology. Cochrane Database Syst Rev. 2016;(6):CD002118

32. Berntsen $\mathrm{S}$, Söderström-Anttila V, Wennerholm UB, et al. The health of children conceived by ART: 'the chicken or the egg?'. Hum Reprod Update. 2019;25(2):137-158.

33. Zhang WY, von Versen-Höynck F, Kapphahn KI, Fleischmann RR, Zhao Q, Baker VL. Maternal and neonatal outcomes associated with trophectoderm biopsy. Fertil Steril. 2019;112(2):283-290.e2.

34. Heijligers $\mathrm{M}$, van Montfoort $\mathrm{A}$, Meijer-Hoogeveen $\mathrm{M}$, et al. Perinatal follow-up of children born after preimplantation genetic diagnosis between 1995 and 2014. J Assist Reprod Genet. 2018;35(11):1995-

35. Maheshwari A, Pandey S, Amalraj Raja E, Shetty A, Hamilton M, Bhattacharya S. Is frozen embryo ansfer better for mothers and babies? Can cumulative meta-analysis provide a definitive answer?.

36. Sha T, Yin X, Cheng W, Massey IY. Pregnancy-related complications and perinatal outcomes resulting from transfer of cryoprese

37. Hack KEA, Vereycken MEMS, Torrance HL, Koopman-Esseboom C, Derks JB. Perinatal outcome of monochorionic and dichorionic twins after spontaneous and assisted conception: a retrospective cohort study. Acta Obstet Gynecol Scand. 2018;97(6):717-726.

38. Gu YF, Zhou QW, Zhang SP, et al. Inner cell mass incarceration in 8-shaped blastocysts does no increase monozygotic twinning in preimplantation genetic diagnosis and screening patients. PLoS ne. 2018;13(1):e0190776.

39. Haimov-Kochman R, Daum H, Lossos F, et al. Monozygotic multiple gestation after intracytoplasmic sperm injection and preimplantation genetic diagnosis. Fertil Steril. 2009;92(6):2037.e112037.e2.037E17.

40. Mian A, Gabra NI, Sharma T, et al. Conjoined twins: From conception to separation, a review. Clin Anat. 2017;30(3):385-396.

E, Reuters B, et al. Preimplantation genetic diagnosis for X,autosome translocations: lessons from a case of misdiagnosis. Hum Reprod. 2013;28(11):3141-3145.
42. PGD jaarverslag 2016. Available at https://www.pgdnederland.nl/jaarverslagen.

3. Wilton L, Thornhill A, Traeger-Synodinos J, Sermon KD, Harper JC. The causes of misdiagnosis and adverse outcomes in PGD. Hum Reprod. 2009;24(5):1221-1228. doi:10.1093/humrep/den488

44. Lench $\mathrm{N}$, Barrett A, Fielding $\mathrm{S}$, et al. The clinical implementation of non-invasive prenatal diagnosis for single-gene disorders: challenges and progress made. Prenat Diagn. 2013;33(6):555-562.

45. Popovic M, Dheedene A, Christodoulou C, et al. Chromosomal mosaicism in human blastocysts: the ultimate challenge of preimplantation genetic testing?. Hum Reprod. 2018;33(7):1342-1354.

46. Farra C, Choucair F, Awwad J. Non-invasive pre-implantation genetic testing of human embryos: an emerging concept. Hum Reprod. 2018;33(12):2162-2167.

47. Leaver M, Wells D. Non-invasive preimplantation genetic testing (niPGT): the next revolution in reproductive genetics?. Hum Reprod Update. 2020;26(1):16-42.

48. Kuznyetsov V, Madjunkova $S$, Antes $R$, et al. Evaluation of a novel non-invasive preimplantation genetic screening approach. PLoS One. 2018;13(5):e0197262. Published 2018 May 10.

49. Ceelen M, van Weissenbruch MM, Roos JC, Vermeiden JP, van Leeuwen FE, Delemarre-van de Waal CA. Body composition in children and adolescents born after in vitro fertilization or spontaneous conception. J Clin Endocrinol Metab. 2007;92(9):3417-3423.

50. Belva F, Painter R, Bonduelle M, Roelants M, Devroey P, De Schepper J. Are ICSI adolescents at risk for increased adiposity?. Hum Reprod. 2012;27(1):257-264.

51. Ceelen $\mathrm{M}$, van Weissenbruch MM, Vermeiden JP, van Leeuwen FE, Delemarre-van de Waal HA. Cardiometabolic differences in children born after in vitro fertilization: follow-up study. I Clin Endocrinol Metab. 2008;93(5):1682-1688.

52. Seggers J, Haadsma ML, Bastide-van Gemert Sl, et al. Blood pressure and anthropometrics of 4-y-old children born after preimplantation genetic screening: follow-up of a unique, moderately sized, randomized controlled trial. Pediatr Res. 2013;74(5):606-614.

53. Scherrer U, Rexhaj E, Allemann Y, Sartori C, Rimoldi SF. Cardiovascular dysfunction in children conceived by assisted reproductive technologies. Eur Heart J. 2015:36(25):1583-1589.

54. Barker DJ. Fetal origins of coronary heart disease. BMJ. 1995;311(6998):171-174. 


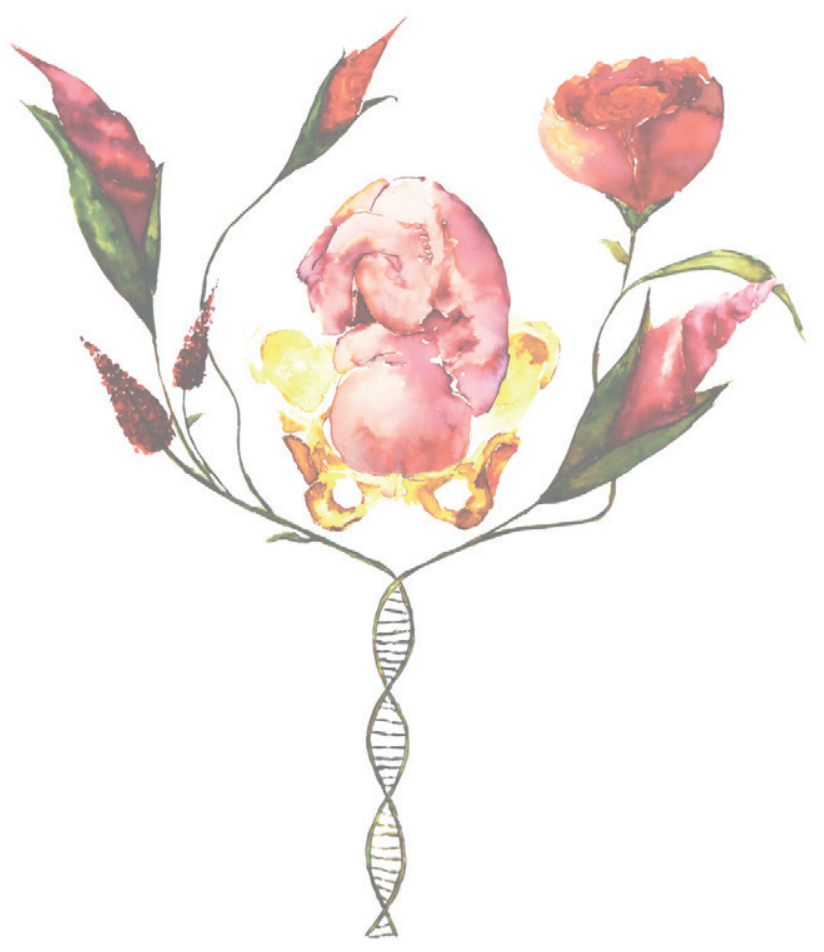

Summary 


\section{Summary}

Preimplantation genetic diagnosis (PGD), also known as preimplantation genetic testing (PGT), was introduced in the Netherlands in 1995. Currently, around 500 couples per year are referred for PGD. Couples opting for PGD have an increased risk of transmitting a genetic disorder to their offspring or an increased risk of miscarriages due to a structural chromosomal rearrangement. PGD makes it possible to select embryos without the familial genetic disorder or the familial unbalanced karyotype. Briefly, the PGD treatment starts with an IVF (with or without ICSI) treatment in order to retrieve oocytes. The fertilization of the oocytes is followed by embryo biopsy and thereafter by genetic analysis of the biopsied cell(s). Only one, and sometimes two, unaffected embryos will be transferred into the uterus.

The complexity of the procedure, particularly the biopsy, and the involvement of human embryos makes PGD a morally sensitive technology. It is therefore that the Maastricht University Medical Center+ (MUMC+) is the only Dutch center licensed to offer PGD services. The MUMC+ collaborates with three so-called transport centers (University Medical Center Utrecht, University Medical Center Groningen, Amsterdam University Medical Center). Together these centers form the alliance PGD the Netherlands. The activities of PGD the Netherlands are annually documented, but had not been evaluated up until this thesis. The Dutch data have also been incorporated in several reports of the European Society of Human Reproduction and Embryology (ESHRE). However, (international) data regarding the safety of PGD are scarce.

The central aim of this thesis was to evaluate the safety of PGD, with special attention for the health of the women pregnant after PGD and for pre- and postnatal health of children conceived after PGD.

Chapter 2 describes the results of a retrospective study on the risk of obstetric complications (including preeclampsia, HELLP, hypertension, gestational diabetes and placental problems) in pregnancies following PGD compared to pregnancies following IVF/ICSI. All included pregnancies were conceived between 2004 and 2014. Data regarding parental characteristics (age, subfertility, genetic carrier status for the PGD couples), the PGD and IVF procedure (use of ICSI, number of biopsied cells, genetic analysis technique, number of transferred embryos), fetal loss, and birth 
measurements were presented separately for singleton and multiple pregnancies. Additionally, the data were compared to national population data. The risk of obstetric complications in the cohort of both singleton and multiple pregnancies following PGD was comparable to the risk in the pregnancies following IVF/ICSI. Remarkable findings were the lower incidence of stillbirths in the PGD singletons group and the higher incidence of monozygotic twins in the PGD multiple group. No explanation was found for the lower incidence of stillbirths. Future exploration of this finding was advised since earlier studies reported a possible higher fetal mortality after PGD.

The perinatal health of the children born after PGD was evaluated in chapter 3. All pregnancies following PGD that were conceived between the start of PGD in 1995 until 2014 were included. Data were collected from medical files and by questionnaires filled in by the parents. Most important outcome measures were the incidence of congenital abnormalities, the misdiagnosis rate, birth parameters, perinatal mortality and hospital admissions in the perinatal period. The data were compared to data from other published PGD cohorts and to population data. The risk of congenital abnormalities was not increased in the Dutch PGD cohort. Only one misdiagnosis was discovered during almost twenty years of PGD and concerned a complex PGD protocol for a chromosomal translocation including the $\mathrm{X}$ chromosome. The corresponding pregnancy resulted in an early miscarriage due to a chromosomal imbalance. Calculation of the mean birth parameters of the children included in this cohort showed a mean pregnancy duration and birth weight that were comparable to the population norm. Part of the children were born premature and/or small for gestational age (SGA; $20 \%$ and $15 \%$ respectively). The incidence of hospital admissions in this cohort was comparable to the incidence of prematurity and SGA, which indicates a correlation between the prematurity rate, birth weight and hospital admissions. Only three stillbirths were reported of whom two were part of a multiple pregnancy. None of the children were stillborn due to the genetic condition for which PGD was performed, thus no additional misdiagnosis were found.

In chapter 4 the growth and health of five-year-old children born after PGD was compared to that of children born after IVF/ICSI and children from families with a genetic disorder born after natural conception (NC). The execution of this study was quiet an effort for the children, their parents and the research group. Most of the children visited the hospital to undergo the examinations, with a total turnaround time of about 3 hours. The growth (based on birth parameters, current height, weight and body circumferences) was comparable for all three groups. Additionally, the children underwent a general and a neurological examination during which tendon reflexes and coordination skills were evaluated. Most children performed flawlessly, and a couple of children in all the three groups had some difficulty with standing and hopping on one leg. Though none of the included children showed abnormal neurologic behavior. During the examination, the children's parents were asked to fill in questionnaires about the health, medical history and early motor development of their children. Evaluation of the parent's answers showed no difference between the three groups. The mean age at which early motor milestones were achieved was comparable for all three groups. The percentage of children with an acute illness in their medical history was strikingly high in all three groups (82.5-90.0\%). This finding was interpreted as a possible result of precautionary measures in children who were specially conceived (PGD and IVF/ICSI group) or who were born after a pregnancy with a special intervention (invasive prenatal testing; NC group), and thus not as a result of the IVF or PGD procedure on itself. It may, however, be valuable to re-evaluate this finding in a larger group of children from different ages and to compare the findings to data of naturally conceived children born after an uncomplicated pregnancy.

The second part of the study of the five-year-old children born after PGD focused on the cognitive and socio-emotional development (chapter 5). All children underwent extensive neuropsychological testing. Their parents and teachers were asked to fill in questionnaires evaluating the children's executive functioning and socio-emotional development. The children born after PGD showed levels of cognitive and socioemotional development at the age of five that are within the normal range. Striking was, though, that the teachers' scores revealed more externalizing (e.g. hyperactive, aggressive) and total problem behavior in PGD children than in IVF children. This difference was not found when both groups of children were compared to the NC group. This finding was difficult to explain, but may be the result of the higher incidence of affected first degree family members in the PGD group when compared to the NC group. Since the mean scores were within the norm range, there was no prove that either the biopsy or the potential extra psychological burden resulting from the presence of a genetic disorder in the family are associated with adverse socioemotional development. 
In chapter 6 we recapitulate the results of the conducted studies and discuss the possible effects of new innovations in PGD practice on these study results. Relevant findings for clinical practice are highlighted and knowledge gaps are noted, followed by advice regarding future research topics.

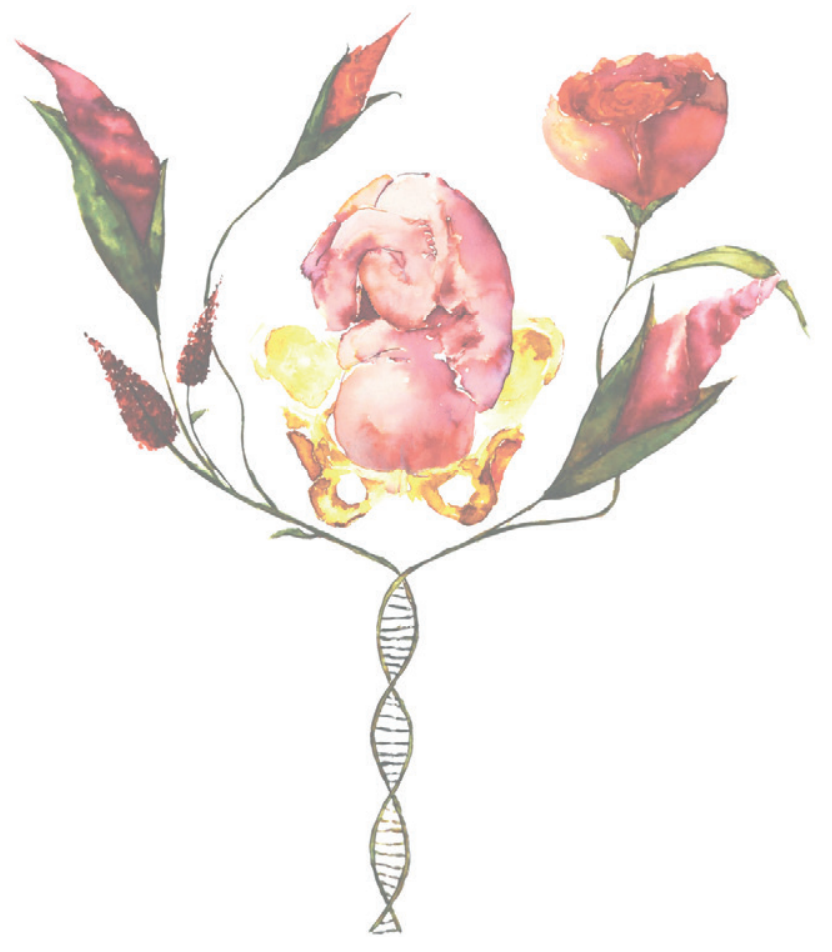

Samenvatting 


\section{Samenvatting}

Pre-implantatie genetische diagnostiek (PGD), ook wel bekend als pre-implantatie genetisch testen (PGT), werd in 1995 in Nederland geïntroduceerd. Momenteel worden rond de 500 paren per jaar verwezen voor PGD. Paren die opteren voor PGD hebben een verhoogd risico op nakomelingen met een genetische aandoening of een verhoogd risico op miskramen ten gevolge van een structurele chromosomale afwijking. PGD maakt het mogelijk om embryo's te selecteren zonder de familiaire genetische aandoening of de familiaire ongebalanceerde chromosoomafwijking. Samengevat, begint de PGD-behandeling met een IVF-behandeling (met of zonder ICSI) om eicellen te verkrijgen en vervolgens in het laboratorium te bevruchten. Enkele dagen na de bevruchting van deze eicellen vindt er een biopsie van het embryo plaats, gevolgd door genetische analyse van de gebiopteerde cel(len). Slechts één, en soms twee, niet-aangedane embryo's worden in de baarmoeder teruggeplaatst.

De complexiteit van de procedure, met name de biopsie, en de betrokkenheid van menselijke embryo's maken PGD een moreel gevoelige technologie. Derhalve is het Maastricht Universitair Medisch Centrum (MUMC+) het enige Nederlandse centrum dat een vergunning heeft om PGD aan te bieden. Het MUMC+ werkt samen met drie zogenaamde transportcentra (Universitair Medisch Centrum Utrecht, Universitair Medisch Centrum Groningen, Amsterdam Universitair Medisch Centrum). Samen vormen deze 4 UMC's "PGD Nederland". De activiteiten van PGD Nederland worden jaarlijks gedocumenteerd, maar werden tot nu toe niet geëvalueerd. Daarnaast zijn deze data ook in meerdere rapportages van de "European Society of Human Reproduction and Embryology" (ESHRE) geïncludeerd. Echter, (internationale) studies over de veiligheid van PGD zijn schaars.

Het hoofddoel van dit proefschrift was om de veiligheid van PGD te evalueren, met speciale aandacht voor de gezondheid van de vrouwen die zwanger zijn na PGD en voor de pre- en postnatale gezondheid van kinderen die verwekt zijn middels PGD.

Hoofdstuk 2 beschrijft de resultaten van een retrospectief onderzoek naar het risico op obstetrische complicaties (inclusief preeclampsie, HELLP, hypertensie, zwangerschapsdiabetes en placentaire problematiek) in zwangerschappen na PGD vergeleken met zwangerschappen na IVF/ICSI. De geïncludeerde vrouwen waren zwanger tussen 
2004 en 2014. Gegevens met betrekking tot de karakteristieken van de ouders (leeftijd, onvruchtbaarheid, genetische status voor de PGD-paren), de PGD- en de IVFprocedure (gebruik van ICSI, aantal gebiopteerde cellen, genetische analysetechniek, aantal teruggeplaatste embryo's), intra-uteriene vruchtdoden en geboorteparameters werden afzonderlijk gepresenteerd voor eenling- en meerlingzwangerschappen. Bovendien werden deze gegevens vergeleken met gegevens van de Nederlandse bevolking. Het risico op obstetrische complicaties in het cohort van zowel eenling- als meerlingzwangerschappen na PGD was vergelijkbaar met het risico bij zwangerschappen na IVF/ICSI. Opmerkelijke bevindingen waren de lagere incidentie van intra-uteriene vruchtdoden in de PGD-eenlinggroep en de hogere incidentie van monozygote (eeneiige) tweelingen in de PGD groep. Er werd geen verklaring gevonden voor de lagere incidentie van intra-uteriene vruchtdoden. Toekomstige evaluatie van deze bevinding werd geadviseerd omdat eerdere studies wel een mogelijk hogere foetale mortaliteit na PGD meldden.

De perinatale gezondheid van de kinderen geboren na PGD wordt geëvalueerd in hoofdstuk 3. Alle zwangerschappen die ontstonden na PGD tussen 1995 (start van PGD) en 2014 werden geïncludeerd. De gegevens werden verkregen middels dossieronderzoek en vragenlijsten ingevuld door de ouders zelf. De belangrijkste uitkomstmaten waren de incidentie van aangeboren afwijkingen, het aantal misdiagnoses, geboorteparameters, perinatale sterfte en ziekenhuisopnames in de perinatale periode. De gegevens werden vergeleken met gegevens van andere gepubliceerde PGD-cohorten en met populatiegegevens. Het risico op aangeboren afwijkingen was niet verhoogd in het Nederlandse PGD-cohort. Er was slechts één misdiagnose gedurende bijna twintig jaar PGD. Het betrof een complex PGDonderzoek voor een chromosomale translocatie waarin het X-chromosoom was betrokken. De bijbehorende zwangerschap resulteerde in een vroege miskraam vanwege een chromosomale onbalans. De kinderen in dit cohort toonden een gemiddelde zwangerschapsduur en hun geboortegewicht was vergelijkbaar met de populatienorm. Een deel van de kinderen werd prematuur en/of dysmatuur geboren (respectievelijk $20 \%$ en 15\%). Het aantal ziekenhuisopnames was vergelijkbaar met de incidentie van prematuriteit en dysmaturiteit. Dit zou kunnen wijzen op een correlatie tussen prematuriteit, het geboortegewicht en het aantal ziekenhuisopnames. Slechts drie intra-uteriene vruchtdoden werden gemeld, twee van de drie kinderen waren deel van een meerlingzwangerschap. Geen van de kinderen overleed intra-uterien ten gevolge van de genetische aandoening waarvoor PGD werd uitgevoerd. Er werden derhalve geen nieuwe misdiagnoses gerapporteerd.

In hoofdstuk 4 wordt de groei en gezondheid van vijf jaar oude kinderen geboren na PGD vergeleken met die van kinderen geboren na IVF/ICSI en kinderen uit families met een genetische aandoening geboren na natuurlijke conceptie (NC). De uitvoering van deze studie was zeer inspannend voor de kinderen, hun ouders en de onderzoeksgroep. De kinderen bezochten het ziekenhuis om diverse onderzoeken te ondergaan, wat in totaal ongeveer 3 uur duurde. Onderdeel van het onderzoek was de evaluatie van de groei (op basis van geboorteparameters, huidige lengte, gewicht en lichaamsomtrek). De groei was voor alle drie groepen vergelijkbaar. Daarnaast ondergingen de kinderen een algemeen lichamelijk onderzoek en een neurologisch onderzoek waarbij peesreflexen en coördinatievaardigheden werden geëvalueerd. De meeste kinderen presteerden feilloos, enkel een paar kinderen in alle drie de groepen hadden enige moeite met staan en springen op één been. Bij geen van de geïncludeerde kinderen werden bij het neurologisch onderzoek afwijkingen gevonden. Tijdens het onderzoek van de kinderen werd aan de ouders gevraagd om vragenlijsten in te vullen over de gezondheid, medische voorgeschiedenis en vroege motorische ontwikkeling van hun kinderen. Evaluatie van de antwoorden van de ouders toonde geen verschil tussen de drie groepen. De gemiddelde leeftijd waarop de vroege motorische mijlpalen werden bereikt, was vergelijkbaar voor alle drie de groepen. Het percentage kinderen met een acute ziekte in hun medische voorgeschiedenis was opvallend hoog in alle drie de groepen (82,5-90,0\%). Deze bevinding werd geïnterpreteerd als een mogelijk gevolg van voorzichtigheid van de ouders ten aanzien van de gezondheid van hun kinderen die op een niet-natuurlijke manier werden verwekt (PGD en IVF/ICSI groep) of waarbij in de zwangerschap aanvullende diagnostiek, namelijk invasieve prenatale diagnostiek, heeft plaatsgevonden (NC groep), en dus niet als een gevolg van de IVF en eventueel PGD-procedure zelf. Het kan echter waardevol zijn om deze bevinding opnieuw te evalueren bij een grotere groep kinderen van verschillende leeftijden en om de bevindingen te vergelijken met gegevens van kinderen die na een natuurlijke conceptie en ongecompliceerde zwangerschap zijn geboren.

Het tweede deel van het onderzoek van de vijf jaar oude kinderen geboren na PGD richt zich op de cognitieve en sociaal-emotionele ontwikkeling (hoofdstuk 5). Alle 
kinderen ondergingen uitgebreide neuropsychologische testen en hun ouders en leerkrachten werden gevraagd om vragenlijsten in te vullen die het uitvoerend functioneren van de kinderen en de sociaal-emotionele ontwikkeling evalueerden. De cognitieve en sociaal-emotionele ontwikkeling van de kinderen geboren na PGD lag binnen het normale bereik. Opvallend was echter dat de scores van de leraren een hogere mate van externaliserend (o.a. hyperactiviteit, agressie) en totaal probleemgedrag vermelden bij PGD-kinderen in vergelijking met IVF-kinderen. Dit verschil werd niet gevonden wanneer beide groepen kinderen werden vergeleken met de NC-groep. Deze bevinding was moeilijk te verklaren, maar kan het gevolg zijn van de hogere incidentie van een aangedaan eerstegraads familieleden in de PGD-groep in vergelijking met de NC-groep. Omdat de gemiddelde scores binnen het normbereik lagen, zijn er geen aanwijzingen dat de embryobiopsie of de potentiële extra psychologische belasting door de aanwezigheid van een genetische aandoening in het gezin geassocieerd zijn met ongunstige sociaal-emotionele ontwikkeling.

In hoofdstuk 6 recapituleren we de resultaten van de uitgevoerde onderzoeken en bespreken we de mogelijke effecten van nieuwe innovaties in de PGD-praktijk op deze onderzoeksresultaten. Relevante bevindingen voor de klinische praktijk en kennislacunes worden uitgelicht, gevolgd door advies over toekomstige onderzoeksonderwerpen.

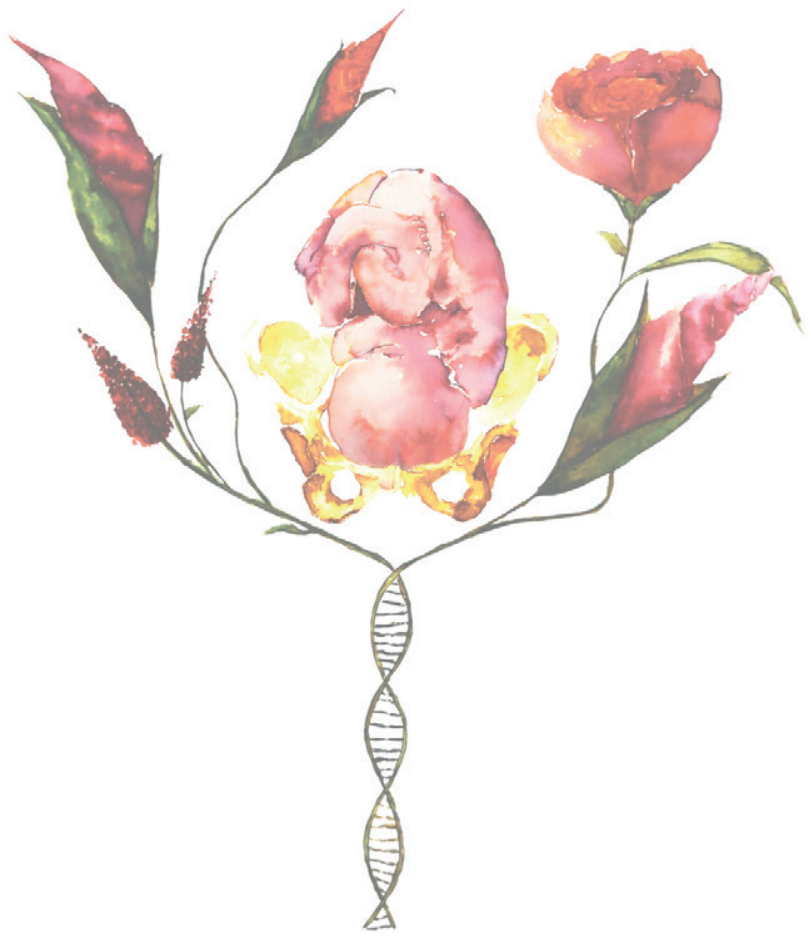

Valorization 


\section{Valorization}

This thesis focuses on the safety of preimplantation genetic diagnosis (PGD), more precisely on the growth, health and development of children born after PGD. The societal value of the results of this thesis is described in this paragraph.

The World Health Organization defines 'patient safety' as "The absence of preventable harm to a patient during the process of healthcare and reduction of risk of unnecessary harm associated with healthcare to an acceptable minimum. An acceptable minimum refers to the collective notions of given current knowledge, resource available and the context in which care was delivered weighed against the risk of non-treatment or other treatment". ${ }^{1}$

PGD is a complex and morally sensitive technology that involves biopsy, analysis and selection of human embryos, as well as the application of in-vitro fertilization (which is considered to be an invasive treatment) in fertile women with or without a genetic disorder themselves. It is therefore, that both government and society may have concerns about the safety of this procedure. The Dutch government is involved in the legislation of PGD and decided that only one Dutch center is licensed to coordinate the activities regarding PGD healthcare in the Netherlands, which is the Maastricht University Medical Center+ (MUMC+). Legal and ethical boundaries for performing PGD are formulated in the 'Embryowet' and PGD guidelines were published in 2009 in the Staatscourant. ${ }^{2}$ Part of these guidelines is the obligation to provide annual reports on the PGD cycles performed in the Netherlands. Drawing up such annual report is also advised by the European Society of Human Reproduction and Embryology (ESHRE) PGD consortium. ${ }^{3}$ Up until this thesis, the Dutch data regarding pregnancies and children born following PGD had not been evaluated thoroughly and/or compared to international data. In chapter $\mathbf{2}$ and $\mathbf{3}$ of this thesis we aimed to evaluate these data and gathered additional data in order to assess the short term safety of PGD with regard to the risk of adverse obstetric and perinatal outcome. Additionally, the long term safety of PGD is discussed in chapter $\mathbf{4}$ and $\mathbf{5}$ in which the growth, health and development of 5-year-old children born after PGD is evaluated. Thereby, the majority of the couples whom may consider PGD has no fertility problem and could conceive naturally. Especially for those, the knowledge about the safety of PGD for both mother and child may contribute to their reproductive choice. It is therefore that we 
compared our data to data of pregnancies and children born after natural conception in families with a genetic disorder, since trying to conceive spontaneously might be a realistic alternative for the couples opting for PGD. Data on the health of children born after PGD are scarce and not easily accessible for couples who consider PGD. Earlier studies on the health of newborns and children born following PGD are mostly published in scientific journals and written in scientific language which may be difficult to read for non-medics. Thereby, most of these studies focus on preimplantation genetic screening which is offered to couples with subfertility instead of to couples with a high chance of conceiving a child with a genetic disorder.

In the last couple of years, the number of referrals for PGD has increased tremendously. ${ }^{4}$ More couples apply for PGD. Also more hereditary disorders for which PGD can be offered can be diagnosed. The increasing number of diagnoses in patients in whom a genetic disorder is suspected is due to the improvement of genetic diagnostic techniques. This consequently leads to the ascertainment of more couples with an increased risk of conceiving a child with a genetic disorder. The introduction and growing application of preconception carrier tests is another way of identifying couples at risk for transmitting a genetic disorder to their offspring. A wider application of a delicate medical treatment such as PGD, that is administered with the involvement of the government, should be carefully evaluated. Not only the current study is part of this evaluation, but also other research projects on for instance the decision-making process regarding PGD and the implementation of the PGD National Indications Committee.

As with each medical treatment it is important that guidelines are followed. Additionally, the actual outcome should be in line with the expected outcome. In case of PGD, the expected outcome is the birth of a healthy child, more specifically of a child without the familial genetic disorder for which PGD was performed. The primary aim of PGD is to prevent the birth of a child without such genetic disorder and to soften personal harm for parents and families. As a side effect PGD may lead to a decline in healthcare costs since the diseases for which PGD is performed are, without exception, severe and sometimes even lethal at a young age. PGD, on itself, is however also a costly medical procedure. It is therefore important to evaluate whether the use of PGD introduces (new) health hazards in the forthcoming pregnancy and offspring. The evaluation of such adverse effects is also of economic relevance since these could outweigh the saved costs on a child with a genetic disorder.

Besides economic relevance, there are also psychological aspects which are important to acknowledge when evaluating the application of PGD. PGD makes it possible to select embryos without a certain genetic disorder before an actual pregnancy is established. Only unaffected embryos will be transferred into the uterus. Invasive prenatal diagnosis is an alternative procedure to test whether a specific genetic disorder is transmitted to the offspring and to prevent the birth of affected children. Contrary to PGD, the latter is offered during pregnancy, mostly between a pregnancy duration of 10 and 15 weeks gestational age. If the fetus is affected with the familial genetic disorder, the couple can choose to terminate the pregnancy. Procedures for terminating a pregnancy are a medical abortion with use of medication and vacuum or suction aspiration. Such procedures can have large psychological impact on the couple, especially when performed in several consecutive pregnancies. The psychological impact of the PGD procedure, on the other hand, should also not be underestimated since it can take several years from the application for PGD to the birth of a live born child. Also the necessity of a medical treatment like IVF may have psychological impact.

The preference for either PGD or invasive prenatal testing is a very personal one which may change over time or may be influenced by certain (personal) events or religious background. For instance, as already mentioned, preconception carrier testing is increasingly applied. Such test is mostly offered to consanguineous couples because these have a higher risk for carrying the same autosomal recessive disorder than non-consanguineous couples. Consanguinity is more common in the Middle East, West Asia and North Africa. In some of these populations, a pregnancy termination is due to religious grounds not an option, whereas PGD, on the other hand, may be allowed.

The limited scientific information available on the safety of PGD also makes it difficult for healthcare providers and other professionals, for instance teachers, to judge whether the women pregnant following PGD and the children born following PGD need extra surveillance. The results in this thesis (chapter $\mathbf{2}$ and $\mathbf{3}$ ) may contribute to the formation of (inter)national guidelines regarding the surveillance of women who 
are pregnant following Assisted Reproductive Technology (ART), in particular following PGD. Whereas the second part of this thesis (chapter $\mathbf{4}$ and 5) may be of importance in youth health care as well as for teachers of children born after PGD.

The latter part focuses on the growth, health and development of 5-year-old children born following PGD. Evaluation of the growth and development of children is part of the national screening program. The executing youth health care physicians may not see many children born after PGD and thus lack knowledge about the safety of such procedure and possible effect on the growth and health of the children. Teachers may have never heard of PGD, and parents can be in doubt whether they want to inform the children's teachers about the PGD procedure. Plain and easily accessible information about PGD and the results of this thesis is thus desirable. We provided such information by means of a newsletter to all parents of the children who participated in the study with five-year-old children. Additionally, results of the study have been published in summary and plain language on the website of PGD the Netherlands. Stake holders and Dutch clinical geneticist whom counsel couples about PGD have been informed about the first results during a special organized stake holders day.

This thesis is the start of a broader follow-up program for children born after PGD. This program includes the study of 8-year-old children born after PGD, whom are compared to IVF/ICSI children and naturally conceived children of the same age. These 8-year-old children were the same children as included in the study of 5-yearolds. Examining the children at an older age contributes to the knowledge about longterm safety of PGD. Additionally, collection of complementary data on body composition, blood pressure and vascular dysfunction is part of the program in order to collect information about cardiometabolic outcome in the three groups of children. This information is of importance for the future health of the children since it gives information about cardiovascular morbidity and mortality risks later in life.

In summary, the evaluation of the safety of PGD is not only an important scientific and/or medical topic, but is also socially and economically relevant. Techniques and procedures necessary for PGD are, however, quickly developing over time, due to which the results of this thesis may become less valuable in the nearby future. The applied study methods and procedures can, though, be a blueprint for future followup studies on the safety of PGD.

\section{References}

1. https://www.who.int/patientsafety/en/

Bussemaker M. Regeling preimplantatie genetische diagnostiek van de staatssecretaris van Volksgezondheid, Welzijn en Sport (Regulations of the State Secretary of Public Health, Welfare and Sport on the rules concerning PGD). Staatscourant Koninkrijk der Nederlanden 2009; 42(42):1-12.

3. Harton G, Braude P, Lashwood A, et al. ESHRE PGD consortium best practice guidelines for organization of a PGD centre for $\mathrm{PGD} /$ preimplantation genetic screening [published correction appears in Hum Reprod. 2012 Aug;27(8):2569]. Hum Reprod. 2011;26(1):14-24. doi:10.1093/humrep/deq229

4. Annual reports PGD the Netherlands. Available at: https://www.pgdnederland.nl/jaarverslagen 


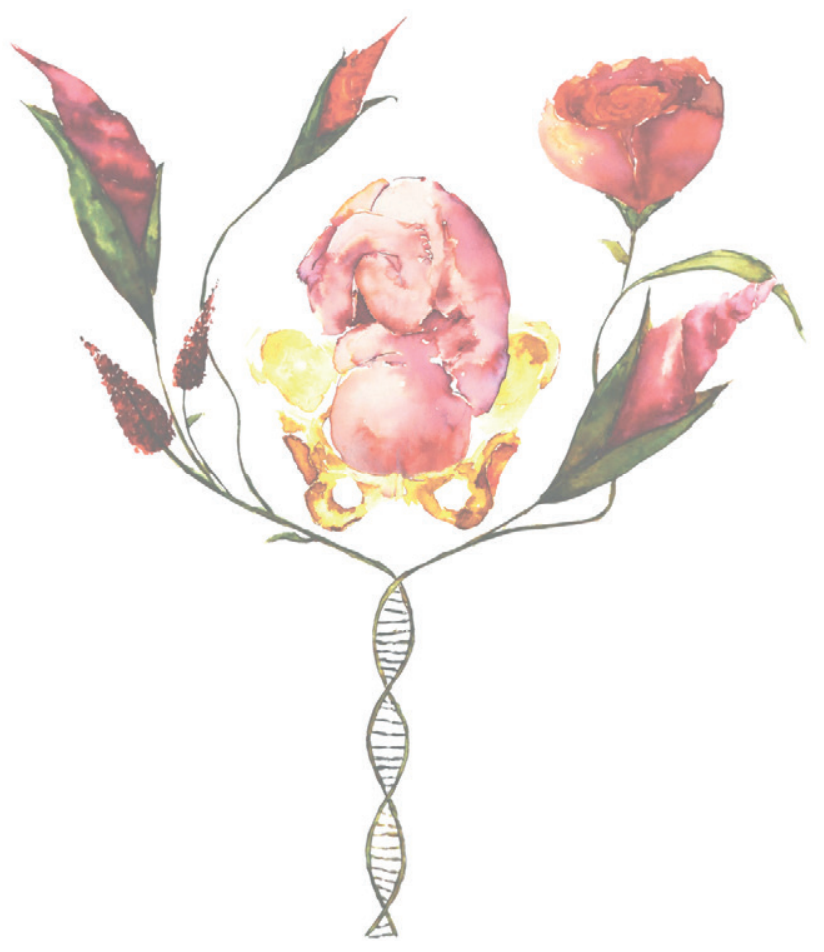

Dankwoord 


\section{Dankwoord}

Mijn dankwoord, de plek om eenieder te bedanken die belangrijk voor mij is geweest tijdens de totstandkoming van dit boekje en ver daarbuiten.

Ten eerste was mijn proefschrift nooit tot stand gekomen zonder de deelnemende kinderen. Ik heb genoten van de inzet en trotse gezichten van de 5- en 8-jarige kinderen tijdens de onderzoeksdagen in het ziekenhuis en bij de kinderen thuis. Sommige kinderen vonden het spannend, anderen kletsten aan een stuk door. We hebben heel veel mooie tekeningen mogen ontvangen. Ook de ouders en leraren van de deelnemende kinderen wil ik bedanken voor het (soms urenlang) invullen van onze vragenlijsten. Net als de kinderen waren de deelnemende ouders ontzettend enthousiast en natuurlijk trots als een pauw wanneer hun kind, veelal met stralende glimlach, de onderzoekskamer uit kwam. Tevens hebben deze ouders mij onbewust gevormd tot de klinisch geneticus die ik nu ben, door hun verhaal met mij te delen over de impact van de erfelijke aandoening op hun gezin en in het dagelijks leven. Vele foto's van hun dierbare aangedane kinderen of andere familieleden heb ik mogen bewonderen. Dit heeft een speciale diepgang in mijn kennis over genetica en erfelijkheid gebracht, een diepgang die niet in studieboeken te vinden is. Deze mooie en ontroerende verhalen hebben mij gedurende het gehele traject gemotiveerd om dit proefschrift vorm te geven.

Natuurlijk wil ik ook graag mijn promotor en copromotoren bedanken. Prof. dr. Christine de Die-Smulders, beste Christine, ik kan me het moment nog herinneren waarop ik jou vertelde dat ik graag zou willen promoveren. Je was totaal niet verrast, maar juist in afwachting van dit besluit. Deze reactie tekent jou, je hebt oog voor iemands professionele ontwikkeling maar ook voor de persoon achter de professional. Jij begrijpt dat privé en werk soms in elkaar overvloeien en gaf mij de ruimte om daarmee om te leren gaan. Je bent kritisch en weet mij altijd te stimuleren om de zogenaamde puntjes op de $\mathrm{i}$ te zetten. Ook als klinisch geneticus kan ik veel van je leren, want tijdens het onderzoek heb ik gemerkt hoeveel waardering de ouders voor jou als dokter hebben. Menig vriendelijke groet kreeg je van de ouders die wij zagen! De huidige corona-situatie heeft ons werk erg veranderd waardoor we elkaar helaas nog weinig in real-life zien. Desalniettemin, ga ik vol enthousiasme de toekomst 
tegenmoet en ben ik blij om 'jouw' PGD team te mogen versterken en daarmee nog veel van jou te kunnen leren!

Dr. Yvonne Arens, beste Yvonne, vanaf het laatste jaar van mijn basisopleiding tot op heden zijn wij aan elkaar 'gekoppeld'. Je begon als mijn stagebegeleider, werd vervolgens mijn opleider en al snel ook copromotor. Ik waardeer jouw 'to-the-point' manier van werken. Jouw betrokkenheid als copromotor én opleider zal soms best moeilijk zijn geweest maar deze combinatie heeft er mede voor gezorgd dat het mij gelukt is om promotie en opleiding te combineren. "Hoe gaat het met je?" Een doodnormale vraag die we vaak te pas en te onpas stellen, maar jij lijkt hem heel doordacht en op de juiste momenten te stellen. De gesprekken die hierop volgden heb ik altijd zeer gewaardeerd en hielpen mij om orde in mijn hoofd te scheppen. Inmiddels zijn we ook binnen het prenatale team directe collega's. We begrijpen elkaars manier van werken en hebben altijd genoeg aan elkaar te vertellen, volgens mij is dat een mooie basis voor een zeer prettige samenwerking!

Dr. Aafke van Montfoort, beste Aafke, wat was je verrast toen ik vroeg of je mijn copromotor wilde worden. Voor mijzelf was hier geen twijfel over mogelijk. Ondanks de minder frequente contacten is jouw aandeel in dit traject altijd groot geweest. Jouw rol kenmerkt zich door jouw frisse blik en kunde om alles net vanuit een ander perspectief te bekijken. Je was altijd kritisch bij de opzet van het onderzoek en nam de tijd om met mij te sparren over de diverse mogelijkheden en invalshoeken. Daarnaast heb je mij geholpen met de statistische analyses en wist je voor extra diepgang te zorgen met jouw kennis over embryologie en IVF. Ik ben onder de indruk van jouw wetenschappelijke expertise en de effort die jij in je werk steekt!

De uitgevoerde studies waren niet tot stand gekomen zonder de subsidies van ZonMw en het Academisch Fonds van het MUMC+, evenmin zonder de betrokkenheid van ons ZonMw projectteam. Dit team, bestaande uit eerder genoemden en prof. dr. Guido de Wert, prof. dr. Wybo Dondorp, dr. Ron van Golde, dr. Mark van der Hoeven, dr. Lisa Jonkman, drs. Marleen van der Sangen en drs. Loes Verheijden was de basis van dit onderzoeksproject. Samen hebben we onze data mogen presenteren bij het ministerie van Volksgezondheid, Welzijn en Sport in aanwezigheid van meerdere collega's uit het land. Dank voor deze mogelijkheid!
Gedurende mijn promotietraject zijn er natuurlijk nog meer collega's betrokken geweest die ik hier graag in willekeurige volgorde wil benoemen. Amber, tijdens mijn eerste stage bij de klinische genetica sprak ik jou regelmatig over jouw promotietraject. Destijds was de mogelijkheid om te promoveren nog niet echt in mij opgekomen maar jouw verhalen over dit onderzoek waren voor mij een eye-opener. Uiteindelijk was de keuze snel gemaakt toen mij werd gevraagd om jouw werk voort te zetten. Dank voor deze mogelijkheid en heel veel geluk en succes met je verdere carrière binnen de psychiatrie. Vyne, Rick, Femke, Joyce en Etiënne heel erg bedankt voor 'de extra handen' tijdens het onderzoeken van de kinderen. Mede dankzij jullie inzet hebben we deze mooie inclusie-aantallen kunnen bereiken. Joyce en Kelly het is altijd fijn om even te kunnen sparren met mede-promovendi. Jullie zijn inmiddels gepromoveerd, nogmaals gefeliciteerd! Andrea, heel erg bedankt voor de statistische ondersteuning die ik vaak zo hard nodig had, evenals jouw input als coauteur. Edith, Aimee en Jos bedankt voor jullie input in de stukken over de technische aspecten van PGD en voor de gezellige theekransjes in de wandelgang. Ik vergeet nooit meer de 'bemoedigende' vergelijking van Aimee toen ik vertelde dat ik zwanger was: "promoveren en zwanger, dus jij gaat twee keer bevallen dit jaar?!". Twee keer in één jaar is door de huidige corona-situatie niet gelukt, maar ik ga des te meer genieten van deze speciale 'bevalling'!

Zoals eerder genoemd heb ik mijn promotietraject altijd gecombineerd met patiëntenzorg. Ik ben mijn collega's van de klinische genetica dan ook dankbaar voor deze mogelijkheid. Han, Els, Maaike, Margje, Encarna, Ingrid, Paula en Edward bedankt voor jullie vertrouwen en flexibiliteit waardoor ik de mogelijkheid kreeg om nog extra schijfverlof te nemen. Kim en Suzanne, de koffiemomentjes en vooral de etentjes gevolgd door een slechte film in de bioscoop zijn de afgelopen jaren vaak een zeer welkome afleiding geweest. Ik hoop dat deze dates in de toekomst nog vaak mogen plaatsvinden, dus Suzanne laat het weten wanneer je weer in Nederland bent! Connie, als mijn mentor en stagebegeleiding heb je een belangrijke rol in mijn opleiding gespeeld. Je bent een voorbeeld voor de vrouwen die carrière en moederschap willen combineren! Daarnaast wil ik je natuurlijk ook erg bedanken voor jouw rol als voorzitter van de beoordelingscommissie. Nienke en Marieke, bedankt voor het wegwijs maken in alle PGD bestanden en follow-up lijsten. Ook de dames van onze polikliniek wil ik bedanken voor het hartelijke ontvangst van de deelnemende kinderen en hun ouders en de bijdrage aan de planning van de onderzoeksdagen. 
Graag wil ik niet alleen de voorzitter, maar ook de andere leden van de beoordelingscommissie bedanken. Prof. dr. Spaanderman, Prof. dr. Devriendt, dr. den Hartog en dr. Bijlsma, hartelijk dank voor de tijd en aandacht die $u$ aan dit proefschrift geschonken heeft.

Chantal, jij bent lange tijd mijn collega en kamergenootje geweest, zowel in het Noord gebouw als tijdens congressen en/of cursussen. Onze verschillende manieren van werken hebben ervoor gezorgd dat we veel van elkaar konden leren. Jij hebt mij meerdere malen een spiegel voorgehouden en liet mij dingen vanuit een ander perspectief bekijken. Naast hard werken was er natuurlijk genoeg tijd voor een gezellig praatje, waardoor er al snel een vriendschap is ontstaan. Helaas voor onze afdeling heb jij besloten om een ander carrière pad te bewandelen, een keuze die ik nog altijd bewonder. Gelukkig is onze vriendschap blijven bestaan. Ik waardeer het daarom enorm dat jij mijn paranimf bent!

Kim, je bent een vriendin van het eerste uur. We hebben veel meegemaakt en menig 'BFF-ketting' versleten. Door de jaren heen waren er ook periodes waarin we minder contact hadden, toch zijn we elkaar nooit uit het oog verloren. Inmiddels hebben we ieder onze eigen droombaan, een lieve partner en 2 kids om trots op te zijn én natuurlijk een speciaal plekje in elkaars hart. Hoewel onze hechte vriendschap a genoeg is om jou als paranimf te vragen, heb je ook nog een talent voor organiseren en presenteren. Super leuk om ook dit belangrijke moment in mijn leven samen met jou te delen!

Meiden van Kwart op Ein, eveneens vriendinnen vanaf de basis- en middelbare school. Tijdens onze studietijd is vrijwel ieder van ons de wereld buiten Velden gaan verkennen, waarna de meesten weer zijn teruggekeerd. We hebben al zo veel leuke en minder leuke momenten samen meegemaakt! Onze vriendschap is voor mij echt speciaal. Ik hoop dat de toekomst nog vol zit met gezellige samenkomsten met vooral veel onnozele gesprekken en natuurlijk veel chips!

Marjolein, Roos, Laura en Lokke, natuurlijk wil ik ook jullie benoemen in dit dankwoord. Onze allereerste onderwijsgroep was de basis van onze vriendschap. We volgen inmiddels ieder ons eigen carrière pad in onze eigen stad/ons eigen land maar spreken elkaar nog regelmatig. Dank voor jullie bemoedigende woorden en feedback!
Ik hoop dat we ondanks onze drukke banen deze mooie vriendschap kunnen blijven behouden.

Hay en Diny, Ruud en Daphne, vanaf het begin heb ik mij welkom gevoeld binnen de familie Geurts. De eerste kerstkaart met de wens om me snel thuis te voelen binnen jullie gezin, heb ik nog altijd bewaard. Jullie zijn een ontzettende steun voor ons en hebben regelmatig met veel plezier op de kinderen (inclusief onze kat Pip) gepast wanneer wij extra tijd voor ons werk nodig hadden. Ook de gezamenlijke etentjes op donderdag zijn altijd gezellig ondanks dat jullie doodmoe moeten zijn na een dag met alle kleinkinderen. Wat mag ik van geluk spreken met mijn schoonfamilie!

Pap en mam, voor jullie kom ik woorden te kort. Jullie hebben mij normen en waarden bijgebracht en geleerd wat doorzettingsvermogen is. Welke keuzes ik ook maak, jullie zullen mij altijd steunen. Trots zijn jullie op elk van de kinderen en kleinkinderen. Ik hoop dat jullie, net als ik, van deze dag zullen genieten. Uiteindelijk is mijn promotie ook een beetje jullie verdienste. Ik hou van jullie!

Stan en Julia, we komen uit hetzelfde nest, maar zijn zo verschillend. Stan, jij staat altijd met beide benen op de grond en geniet van het leven met Maddy en de kids. Stiekem heb ik al heel veel opvoedtrucjes van mijn kleine broertje (en schoonzus) afgekeken. Zo leuk om te zien hoe jij van rebelse puber tot liefdevolle partner en vader bent uitgegroeid! Juul, jij ontdekt, ervaart, analyseert en fantaseert erop los. Jouw artistieke leven is niet aan mij besteed maar ik heb er des te meer bewondering voor! Heerlijk om te zien hoe jij jezelf bent, daar kan menig mens van leren! Ik weet zeker dat je een prachtige en wonderlijke toekomst tegemoet gaat. Natuurlijk ook bedankt voor de mooie illustratie voor de kaft van dit proefschrift.

Lieve Giel, je brengt rust en stabiliteit en vooral ook heel veel liefde in mijn leven. Ik geniet ontzettend van het dorpse, misschien volgens anderen wel burgerlijke leven met jou en onze twee schatten van meiden. We zijn ontzettend snel van verliefd stelletje naar samenwonend, en vervolgens 'ouders van' gegaan, en genieten met volle teugen van elke nieuwe stap in ons leven. Loïs en Ella, onze twee kleine prinsesjes, jullie zijn precies zoals ik gedroomd had dat het moederschap zou zijn! Ik verheug me op alle avonturen die wij nog samen met jullie mogen beleven! 


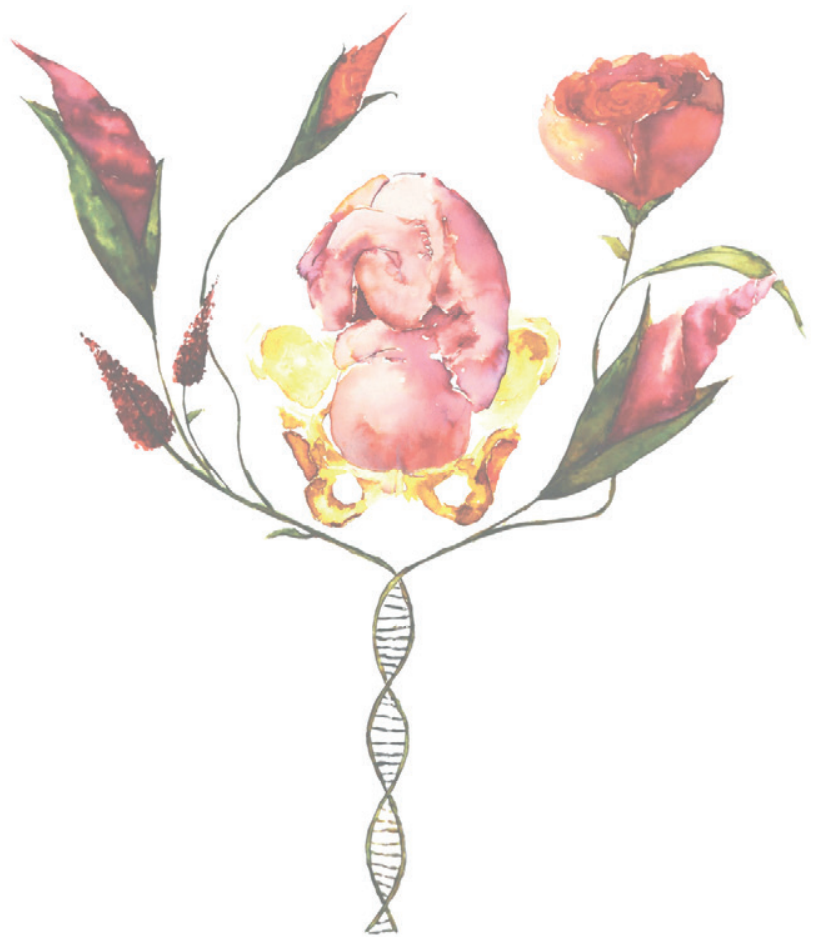

Curriculum vitae 


\section{Curriculum vitae}

Malou Heijligers werd op 29 mei 1988 geboren in Velden, een dorp dat deel uitmaakt van de gemeente Venlo. Zij volgde haar VWO opleiding aan College Den Hulster te Venlo, alwaar zij in 2006 haar diploma mocht ontvangen. Het daaropvolgende jaar startte zij met de opleiding tot HBO Verpleegkundige aan de Fontys Hogeschool te Eindhoven. Zij behaalde in 2007 de bijbehorende propedeuse. Eind 2007 werd zij toegelaten tot de studie Geneeskunde aan de Universiteit Maastricht. In 2013 ontving zij haar artsdiploma.

Tijdens haar studie geneeskunde werd haar interesse voor het specialisme Klinische Genetica al vroeg gewekt. In het vierde jaar van haar opleiding koos zij voor een algemene keuzestage bij de afdeling Klinische Genetica in Maastricht. Dit was het eerste contact met haar promotor Prof. dr. C.E.M. de Die-Smulders. Onder begeleiding van Prof. dr. C.E.M. de Die-Smulders participeerde zij in het kader van haar wetenschappelijke stage in een studie naar de vruchtbaarheid van vrouwen met een mutatie in het BRCA1 of BRCA2 gen. Het laatste deel van haar geneeskunde opleiding bestond uit een klinische stage bij de afdeling Klinische Genetica in Maastricht. Tijdens deze stage lag de focus op de reproductieve genetica waarbij zij werd begeleid door haar latere opleider en co-promotor dr. Y.H.J.M. Arens.

Aansluitend aan haar geneeskunde opleiding startte Malou in 2013 met de opleiding tot klinisch geneticus. In hetzelfde jaar begon zij ook met haar promotieonderzoek onder begeleiding van eerder genoemden en haar tweede co-promotor dr. A.P.A. van Montfoort. Dit onderzoek werd gesubsidieerd door ZonMw en zij ontving een persoonlijke beurs van het Academisch Fonds, MUMC+. In lijn met dit promotietraject werd tijdens haar opleiding duidelijk dat haar interesse vooral bij de reproductieve genetica, ontwikkelingsproblematiek en dysmorfologie lag. Vanwege haar bijkomende interesse in organisatie en management heeft zij tevens een module van de Master Health, Policy Innovation and Management gevolgd. Zij rondde in 2018 haar opleiding tot klinisch geneticus af en startte daaropvolgend als klinisch geneticus in Maastricht met reproductieve genetica, ontwikkelingsproblematiek en dysmorfologie als aandachtsgebieden. Ook na het afronden van haar opleiding bleef zij de patiëntenzorg met haar promotieonderzoek combineren.

Zij heeft een relatie met Giel Geurts. Samen hebben zij twee dochters, Loïs en Ella. 

